
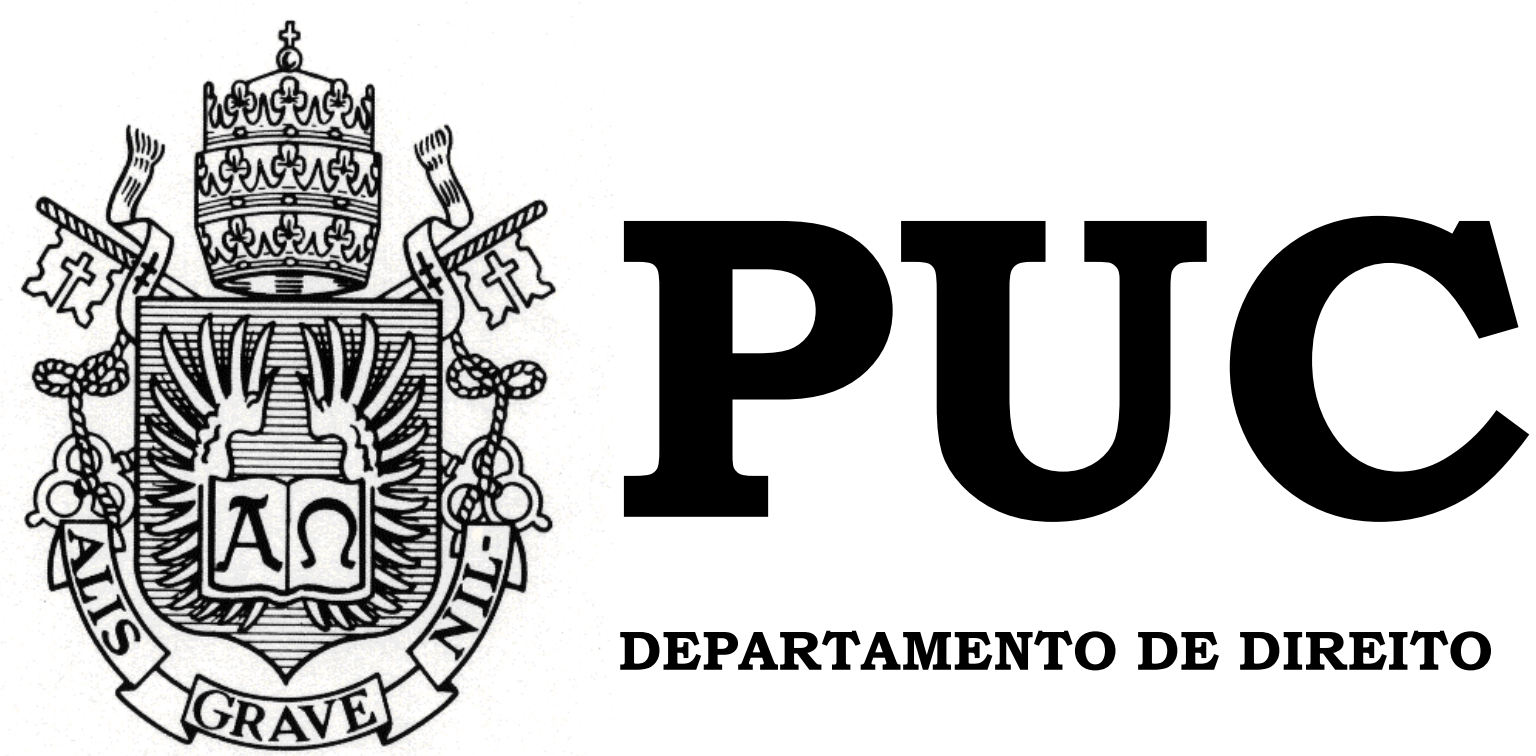

DEPARTAMENTO DE DIREITO

\title{
A ATUAÇÃO DO CONSELHO DE ADMINISTRAÇÃO NAS TENTATIVAS DE TOMADAS HOSTIS DE CONTROLE
}

Por

PEDRO AMARAL IBIAPINA PARENTE

ORIENTADOR: Paulo Eduardo Ramos de Araujo Penna

2018.1

PONTIFÍCIA UNIVERSIDADE CATÓLICA DO RIO DE JANEIRO

RUA MARQUÊS DE SÃO VICENTE, 225 - CEP 22451-900

RIO DE JANEIRO - BRASIL 


\title{
A ATUAÇÃo do CONSELHO DE ADMINISTRAÇÃO NAS TENTATIVAS DE TOMADAS HOSTIS DE CONTROLE
}

\author{
por
}

PEDRO AMARAL IBIAPINA PARENTE
Monografia apresentada ao
Departamento de Direito da
Pontificia Universidade Católica do
Rio de Janeiro (PUC-Rio) como requisito parcial para a obtenção do título de Bacharel em Direito.

Orientador: Paulo Eduardo Ramos de Araujo Penna

2018.1 
"Vamos ao pecado. Os meus amigos sabem que nunca admiti o acionista, senão como um ente imaginário e convencional. O raciocínio que me levara a negá-lo, posto que de aparência lógica, era radicalmente vicioso. Dizia eu quem devendo ser o acionista um interessado no meneio dos capitais e na boa marcha da administração de uma casa ou de uma obra, não se podia combinar esta noção com a ausência dele no dia em que os encarregados da obra lhe queriam prestar contas. Vi caras de diretores vexados e tristes. Um deles, misturando a troça com as lágrimas, virava pelo avesso um adágio popular, e dizia-me em segredo:

- Não se pode ser mordomo com tais juízes.

Diziam-me depois, que o acionista aparecia, ao fim de três chamadas, ouvia distraído o relatório, puxava o relógio, recebia uma cédula, metia-a na urna, e punha-se a panos. Não, retorquia eu, é impossível; se ele fosse um simples fiscal, podia fazer o que faz o da minha freguesia. Mas ele é o próprio capital, é o fundo, é super hanc petram. Sem ele não há casa nem obra ... Mas então como explica? Não explico, ignoro; só sei que o acionista é uma bela concepção.

Homero fazia dos sonhos simples personagens, mandados do céu para trazer recados dos deuses aos homens. O acionista há de ser a mesma coisa, sem a beleza genial de Homero."

Machado de Assis

Bons Dias! (Gazeta de Notícias)

23 de fevereiro de 1889 


\section{AGRADECIMENTOS}

Dedico o presente trabalho a toda minha família, em especial aos meus pais, Nilton e Ana Alice, e meus irmãos, Vitor e Lucas, sem os quais não seria nada, e às minhas avós Maria Alice e Margarida. Agradeço ainda a meus padrinhos Valter e Ana Lúcia e ao meu primo/irmão Fábio. Ainda no âmbito familiar, agradeço ao meu avô Waldir Amaral, pessoa por quem tenho o maior afeto e a mais profunda saudade, e à minha tia Ana Cláudia por ser o maior exemplo profissional que eu poderia ter.

Em sequência, agradeço a todos os meus companheiros do escritório Pinheiro Guimarães, René Brunet, Vitor Horta, Gabriel Ayres, Dan Grossman, Thiago Suguimoto e C. Henrique. Agradeço ainda, de forma destacada, a Leandro Bittencourt por toda paciência e companheirismo demonstrados ao longo do meu período de estágio, e a Nicholas Sousa por todos os ensinamentos transmitidos em um prazeroso ambiente de estágio.

Agradeço aos meus colegas de Lobo e Ibeas, Bárbara Gentile e Ciro Martins por todo tempo convivido e a Gabriel Corrêa por ter sido um grande companheiro, mentor e amigo.

Agradeço a meus grandes amigos de faculdade, em especial, a Daniel Rivera, Luiza Pumar, Isadora Lewkowicz, André Salles, Manuella Malheiro, Bruno Cardoso, João Pedro Germano, Gabriel Ramalho, Louizi Oliveira, Thomas Esch, Daniel Caetani, Isabella Costa, Caroline Berenger, Thiago Merhy, Juliana Herskovits e a todos os outros que contribuíram com a minha jornada acadêmica. 
Agradeço a todos os professores da PUC-Rio pelos ensinamentos transmitidos, em especial, a Francisco Müssnich por todas as lições e infinitas discussões travadas em aula, e por toda inesquecível atenção e auxílio para a elaboração da presente monografia.

Agradeço a Marcelo Trindade e a Pablo Waldemar Renteria pelas críticas construtivas que em muito contribuíram para o fechamento desta monografia.

Agradeço a meu amigo, chefe, professor e orientador, Paulo Penna por todo tempo dedicado à orientação deste trabalho.

Agradeço ao professor Robert J. Jackson da Columbia University pelas aulas que despertaram o interesse no tema do presente trabalho.

Por fim, agradeço a Amanda dos Santos Nogueira da Gama pela pessoa que me tornou. Sem seu companheirismo, reclamações e (eventuais) elogios, eu não seria nada. Muito obrigado por esses quase quatro anos. Que continuemos sob a luz de mil estrelas. 


\section{RESUMO}

O cerne do presente estudo está centrado na atuação do conselho de administração no cenário de uma oferta pública, em especial naquelas que envolvam uma tentativa de tomada hostil de controle. Conforme veremos, nessa seara, há um verdadeiro vácuo legislativo, o que acarreta na necessidade de se regular a matéria através dos próprios institutos do direito societário que atualmente se encontram positivados. Para tanto, nossa análise exigirá que comentemos acerca de diversos temas relativos a esse ramo jurídico que servirão de base para que possamos interpretar como deve se dar a adequada atuação dos membros do conselho de administração nessa conjuntura.

\section{PALAVRAS CHAVE}

Conselho de Administração - Direito Societário - Poder de Controle Controle Minoritário - Controle Gerencial - Conflito de Agência - Deveres Fiduciários - Dever de Diligência - Dever de Lealdade - OPA - Oferta Pública - Interesse Social - Conflito de Interesses - Direito Comparado Business Judgment Rule $\quad-\quad$ Medidas Defensivas. 


\section{SUMÁRIO}

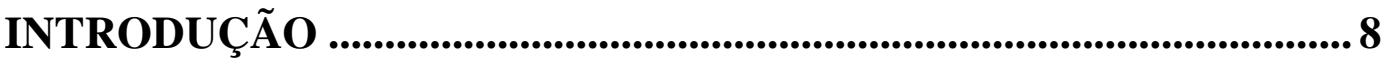

CAPÍTULO 1 - DO PODER DE CONTROLE .......................................10

1.1. Conceito de Poder de Controle ........................................................ 10

1.2. Modalidades de Poder de Controle ................................................11

1.2.1. Controle Totalitário..................................................................................... 12

1.2.2. Controle Majoritário.................................................................................... 13

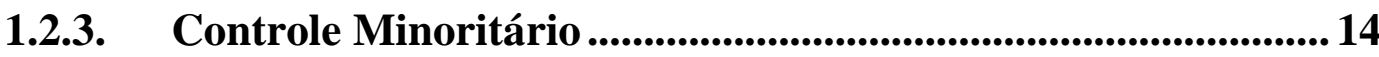

1.2.4. Controle Gerencial................................................................... 15

CAPÍTULO 2. OS PROBLEMAS DECORRENTES DA ALTA DISPERSÃO ACIONÁRIA..................................................................20

CAPÍTULO 3. DOS DEVERES FIDUCIÁRIOS .....................................25

3.1. Dever de Diligência ................................................................................. 28

3.1.1. Business Judgment Rule...................................................................... 32

3.2. Dever de Lealdade .................................................................. 42

CAPÍTULO 4. AS OFERTAS HOSTIS PARA AQUISIÇÃO DO CONTROLE 46

4.1. Conceito de Oferta Hostil e sua Natureza Jurídica ...................47

4.2. Vantagens e Desvantagens das Tomadas Hostis........................ 51

4.3. Aspectos Procedimentais da OPA para Aquisição de Controle 58

CAPÍtUlO 5. A ATUAÇÃO DO CONSELHO DE ADMINISTRAÇÃO NAS TOMADAS HOSTIS.......................................65

5.1. O Interesse Social.............................................................................66

5.1.1. As Teorias do Interesse Social ............................................................... 68

5.1.2. O Interesse Social no Ordenamento Jurídico Brasileiro ......... 71

5.2. O Conflito de Interesses ..................................................................... 73

5.3. O Papel do Conselho de Administração nas Ofertas Hostis no Direito Comparado.................................................................................................8 8 
5.3.1. União Europeia: .................................................................................. 83

5.3.1.1. A Diretiva 2004/25/CE ("Diretiva")............................................. 83

5.3.1.2. Reino Unido ........................................................................................ 85

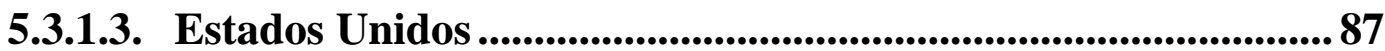

5.3.1.3.1.Unocal Corp. v. Mesa Petroleum Co. 88

5.3.1.3.2.Revlon v. MacAndrews and Forbes Holdings, Inc. 91

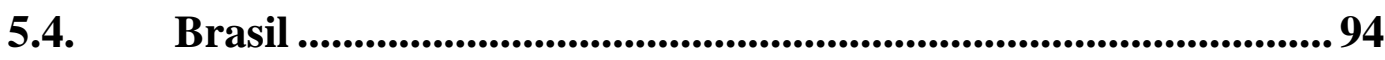

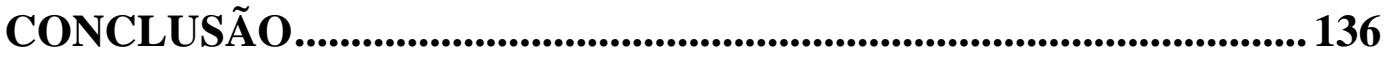

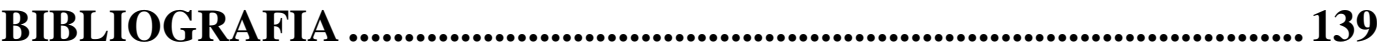




\section{INTRODUÇÃO}

Como tem se notado nos últimos anos, a distribuição do capital acionário tem se modificado. Essa onda de pulverização do capital social traz consigo mudanças significativas na estrutura do poder de controle das companhias.

Em razão da acentuação da pulverização das bases acionárias das companhias abertas brasileiras, diversos questionamentos têm sido levantados acerca da atuação dos administradores. Entre os inúmeros temas relacionados a essa questão, busca o presente estudo analisar, como devem e podem os membros da administração de uma companhia em face de tentativas de tomadas hostis de controle.

Para tanto, iniciaremos nossa análise a partir do próprio conceito de poder de controle a fim de verificar suas diversas facetas e averiguar em quais modalidades se pode cogitar a ocorrência de uma tomada hostil.

Em seguida, delinearemos dois deveres fiduciários relevantes para o objeto do presente estudo e que devem ser sempre observados pelos administradores. Estamos falando dos deveres de diligência e lealdade.

Feitas essas análises preliminares, adentraremos no próprio instituto da oferta hostil, de forma a averiguar seu conceito, suas vantagens e desvantagens, sua positivação em lei e seus aspectos procedimentais. Como resultado, verificaremos que nessa conjuntura, haverá sempre um subjacente potencial conflito de interesses envolvendo os membros da administração da companhia-alvo.

Em vista do conflito mencionado acima, passaremos a analisar as diversas teorias relativas ao interesse social para que possamos, em seguida, conceituar e analisar as formas e maneiras de se tratar o instituto do conflito de interesses. 
Sequencialmente, a fim de buscar referências interpretativas, teceremos breves comentários acerca de como o objeto do presente estudo é tratado na União Europeia, na Inglaterra e nos EUA.

Com base no exposto e nas conclusões extraídas, faremos uma análise de como a atuação dos membros do conselho de administração deve ser enfrentada à luz do ordenamento jurídico brasileiro, apresentando os seus limites e meios disponíveis.

Em seguida, à luz da forma de atuação que fora esmiuçada, demonstraremos como se deu a conduta dos membros do conselho de administração de companhias brasileiras em ofertas públicas nos casos ocorridos no território nacional. 


\title{
CAPÍTULO 1 - DO PODER DE CONTROLE
}

Inicialmente, faz-se necessário tecer breves comentários acerca de um dos mais fundamentais conceitos do direito societário, qual seja, o "poder de controle", para posteriormente abordarmos as diversas formas de se obtê-lo, adentrando, dessa maneira, no tema das tomadas hostis de controle, e, em especial, a forma e a possibilidade de atuação dos administradores quando em face delas.

A importância desta breve e prévia análise consiste no fato de que, conforme demonstraremos, a estrutura da distribuição do capital social com direito de voto impacta diretamente na possibilidade das tomadas hostis. Assim, cumpre previamente elucidar as diversas maneiras pela qual o poder de controle pode existir.

\subsection{Conceito de Poder de Controle}

A Lei n. ${ }^{\circ}$ 6.404, de 15 de dezembro de 1976 (“LSA") define o poder de controle de maneira indireta em seu art. 116 ao conceituar a figura do acionista controlador, afirmando ser este a:

\begin{abstract}
"pessoa, natural ou jurídica, ou o grupo de pessoas vinculadas por acordo de voto, ou sob controle comum, que: a) é titular de direitos de sócio que lhe assegurem, de modo permanente, a maioria dos votos nas deliberações da assembléia-geral e o poder de eleger a maioria dos administradores da companhia; e b) usa efetivamente seu poder para dirigir as atividades sociais e orientar o funcionamento dos órgãos da companhia" .
\end{abstract}

À luz do dispositivo legal transcrito acima, a doutrina societária extrai que o poder de controle é aquele pelo qual:

\footnotetext{
${ }^{1}$ A LSA também define o poder de controle de maneira indireta no $\S 2^{\circ}$ do art. 243 ao disciplinar o conceito de sociedade controlada:

"Art. 243. O relatório anual da administração deve relacionar os investimentos da companhia em sociedades coligadas e controladas e mencionar as modificações ocorridas durante o exercício.

$\S 2^{\circ}$ Considera-se controlada a sociedade na qual a controladora, diretamente ou através de outras controladas, é titular de direitos de sócio que lhe assegurem, de modo permanente, preponderância nas deliberações sociais e o poder de eleger a maioria dos administradores."
} 
"a maioria da Assembleia Geral é pré-constituída mediante reunião na mesma pessoa, ou grupo de pessoas, da titularidade de direitos de voto que asseguram permanentemente a maioria nas reuniões da Assembleia Geral"2.

Exige-se para fins de controle, portanto, que o controlador não só possua direitos de voto que lhe assegurem a maioria nas votações da assembleia geral, mas também que tal maioria lhe seja assegurada (i) de modo permanente e (ii) que dela ele se utilize para (a) efetivamente dirigir as atividades sociais e (b) orientar o funcionamento dos órgãos da companhia.

Dessa forma, caracteriza-se o poder de controle como um poder de fato, isto é, externo à propriedade das ações, tendo por fundamento o direito de voto, e cuja estrutura e exercício variam intensamente a depender, dentre outros aspectos: (i) da distribuição do capital social; (ii) dos poderes atribuídos aos sócios ${ }^{3}$ e/ou administradores; (iii) da liquidez dos valores mobiliários da companhia; (iv) do seu estatuto social e de suas disposições; e (v) das suas relações contratuais ${ }^{4}$.

Conforme explanaremos a seguir, em razão dos fatores elencados acima, o poder de controle pode ser classificado em diversas modalidades, dentre as quais destacam-se quatro: (i) controle totalitário; (ii) controle majoritário; (iii) controle minoritário; e (iv) controle gerencial.

\subsection{Modalidades de Poder de Controle}

Cumpre destacar, desde já, que não se está a debater qual estrutura de controle é per si superior. Este tipo de análise simplista em nada contribuiria ao presente estudo que não busca, de forma alguma, defender

\footnotetext{
${ }^{2}$ LAMY FILHO, Alfredo; PEDREIRA, José Luiz Bulhões (Coord.). Direito das companhias. 2.ed. atual. refor. Rio de Janeiro: GEN, Forense, 2017. p. 599.

${ }^{3}$ Utiliza-se a expressão "sócios" e não "acionistas", pois o poder de controle independe da titularidade das ações com direito a voto. Assim, é possível que se obtenha e exerça o poder de controle por meio de outros instrumentos que não exijam a propriedade das ações, como, por exemplo, o usufruto.

${ }^{4}$ AZEVEDO, Luís André N. de Moura. Controle Minoritário: Dissociação entre Voto e Participação Econômica na Companhia Aberta - Coleção IDSA de Direito Societário e Mercado de Capitais - Volume 8. São Paulo: Quartier Latin, 2017. p. 35.
} 
concepções ideológicas pré-concebidas, mas sim indagar acerca de possíveis lacunas legislativas e questionamentos até então não assentados na doutrina e jurisprudência acerca da possibilidade e extensão da atuação do conselho de administração na ocorrência de tentativas de tomadas hostis de controle.

Feita esta breve ressalta, sigamos à análise dos quatro tipos de estrutura de controle acionário mencionados acima.

\subsubsection{Controle Totalitário}

O controle totalitário configura a forma mais ampla do poder de controle. Tal modalidade restará caracterizada quando uma pessoa ou por um grupo de pessoas detiverem a totalidade dos direitos de voto inerentes às ações que compõe o capital social de uma companhia. O exemplo mais ilustrativo seria a subsidiária integral ${ }^{5}$, na qual uma companhia detém $100 \%$ do capital social de outra companhia.

Entretanto, conforme mencionado, tal modalidade de poder de controle pode ser exercido em conjunto, o que pode ser dar por convenções de voto (usualmente através de acordos de acionistas) ou por meio de situações de fato, como, por exemplo, no caso de dois indivíduos, titulares cada um de metade do capital votante, que sempre exerçam o direito de voto no mesmo sentido. Em tais situações, tratar-se-á de um controle totalitário em conjunto.

Cumpre ressaltar que o controle totalitário é, sem dúvidas, o mais estável e irrestrito. A estabilidade, para fins de controle societário, é verificada, indubitavelmente, no caso do controle totalitário e majoritário

\footnotetext{
5 Art. 251. A companhia pode ser constituída, mediante escritura pública, tendo como único acionista sociedade brasileira.

$\S 1^{\circ}$ A sociedade que subscrever em bens o capital de subsidiária integral deverá aprovar o laudo de avaliação de que trata o artigo $8^{\circ}$, respondendo nos termos do $\S 6^{\circ}$ do artigo $8^{\circ}$ e do artigo 10 e seu parágrafo único.

$\S 2^{\circ}$ A companhia pode ser convertida em subsidiária integral mediante aquisição, por sociedade brasileira, de todas as suas ações, ou nos termos do artigo 252.
} 
(abordado a seguir), nos quais há a manutenção dos direitos de voto de ações correspondentes a mais de $50 \%$ do capital votante, o que fará com que o titular de tais direitos prevaleça em todas as assembleias da companhia, visto que poderá aprovar todas as matérias que exijam tanto o quórum simples (maioria dos presentes na assembleia) quanto o quórum qualificado (maioria do capital votante). Por sua vez, reputa-se absolutamente irrestrito o poder de controle totalitário, pois, até mesmo matérias que exijam a unanimidade poderão ser sempre aprovadas mediante a mera manifestação da vontade do controlador ${ }^{6}$.

\subsubsection{Controle Majoritário}

Trata-se da modalidade mais comum de controle societário existente nas companhias brasileiras. O controle majoritário se verificará quando uma pessoa ou grupo de pessoas ligadas por convenção de voto detiverem mais de $50 \%$ do capital votante de uma companhia, fazendo uso deste para eleger seus administradores. Em tais situações, vislumbra-se que:

"como os eleitores-acionistas têm o poder de vida e morte sobre a administração, podendo a qualquer tempo destituir qualquer administrador em caráter discricionário, fácil é de perceber que, do ângulo sociológico, o poder de controle se projeta para além do foro assemblear, impondo-se sobre a administração como uma força de caráter permanente, condicionando a gestão dos administradores eleitos" "?.

Apesar de serem temas interessantíssimos, não teceremos maiores comentários acerca destas duas modalidades de controle. Tal corte epistemológico se dará pelo fato de o presente estudo ter por objeto a atuação dos administradores quando confrontados com uma tentativa de tomada hostil de controle que, por si própria, conforme exposto adiante, pressupõe a inexistência de um controle majoritário ou totalitário, somente

\footnotetext{
${ }^{6}$ São exemplos de matérias que demandam a aprovação unânime: cisão desproporcional (art. 229, $\S 5^{\circ}$, LSA), mudança de nacionalidade da companhia (art. 300, LSA c/c art. 72, decreto-lei n. ${ }^{\circ}$ 2.627/40), transformação (salvo disposto em contrário no estatuto social) (art. 221, LSA) e aprovação do projeto de estatuto (art. 87, LSA).

${ }^{7}$ GUERREIRO, José Alexandre Tavares. Sociedade Anônima: poder e dominação. Revista de Direito Mercantil, Industrial, Econômico e Financeiro, Nova Série, ano 23, n. ${ }^{\circ}$ 53, p. 73-80, jan./mar. 1984. p. 75-76.
} 
podendo ser verificadas quando o poder de controle é exercido nas modalidades de controle minoritário ou do controle gerencial, a seguir delineadas. Assim sendo, nossa análise abordará essas duas formas de controle de modo mais aprofundado a partir de agora.

\subsubsection{Controle Minoritário}

Conforme mencionado acima, a prevalecente distribuição do capital social das companhias abertas brasileiras sempre foi extremamente concentrada, fazendo com que a regra fosse, e permanece indubitavelmente sendo, o controle totalitário ou majoritário.

Não obstante a manutenção do controle majoritário como regra geral, fato é que, a partir de 2006, a mercado de capitais brasileiro se modernizou, gerando uma significativa dispersão acionária, alavancadas por companhias que adotaram práticas de governança corporativa, que veio a abalar relevantemente o paradigma brasileiro de controle societário até então tido como praticamente imutável.

Assim, em virtude dessa onda de pulverização acionária, passaram a integrar significativamente a realidade brasileira companhias cujo poder de controle não era exercido por quem detivesse 50\% mais 1 ação com direito de voto. Trata-se do controle minoritário, modalidade de poder de controle que ocorre "quando, dada a dispersão das ações da companhia no mercado, um acionista ou grupo de acionistas exerce o poder de controle com menos da metade do capital votante" ${ }^{\text {. }}$

Tal fato poderá ser verificado tanto em cenários de dispersão acionária, nos quais nenhum acionista possui mais de 50\% do capital votante quanto nos casos em que há tal acionista, porém este não use dos direitos de votos das ações que detém para efetivamente orientar a administração da companhia e dirigir suas atividades sociais.

\footnotetext{
${ }^{8}$ EIZIRIK, Nelson. A Lei das S/A Comentada. v. III. São Paulo: Quartier Latin, 2011. p. 412.
} 
Se outrora fora debatida a possibilidade ou existência de um controle minoritário, fato é que atualmente o mercado de valores mobiliários apresenta vasto número de companhias controladas por acionistas minoritários titulares de uma parcela significativa do capital votante. Prova disso são os dados divulgados pela OCDE em um estudo comparado sobre as estruturas de controle nos países-membros ${ }^{9}$, que informa que até:

"o fim de fevereiro de 2013, 44\% das companhias listadas no Novo Mercado declararam em seus formulários de referência que não possuíam um acionista (ou grupo de acionistas) titular da maioria absoluta dos votos, percentual este que já se aproxima do mesmo percentual existente nos mercados de capitais dos Estados Unidos, Inglaterra e Austrália, nos quais se estima que, em média, em torno de $47 \%$ de todas as companhias listadas nestes mercados não possuam acionista controlador titular da maioria absoluta dos votos" $" 10$.

Em relação ao tema do presente estudo, o controle minoritário, como veremos, tem grande relevância, pois, em conjunto com o controle gerencial, tratado a seguir, apenas companhias que se encontrem sob essas duas modalidades de poder de controle podem ser objeto de tomadas hostis.

No que toca à administração da companhia sob controle minoritário, percebe-se que há uma certa relação de dependência entre esta e seu controlador, em termos semelhantes ao que ocorre no controle totalitário e majoritário ${ }^{11}$.

\subsubsection{Controle Gerencial}

Em razão da mencionada onda de dispersão do capital acionário, percebeu-se que em algumas companhias nenhum acionista deteria, em caráter permanente, um percentual de participação acionária votante que o permitisse prevalecer unilateralmente e de forma constante nas decisões assembleares. Consequentemente, em tais companhias não se poderia falar

\footnotetext{
${ }^{9}$ OECD Corporate Governance Factbook. OECD, 2014.

${ }^{10}$ MELLO, Carlos Barbosa e DE CARVALHO, André Ziccardi. Controle Difuso, Poison Pills e Hostile Take Over Bid. In. SIQUEIRA, Marcelo, PEREIRA, Atademes Branco e TREIGER, José Marcos. Brasil S/A: Guia de Acesso ao Mercado de Capitais para Companhias Brasileiras - Rio de Janeiro: RR Donnelley Financial Comunicação Corporativa, 2014. p. 158.

${ }^{11}$ Conforme veremos ao final, tal fato não impediu que em diversos casos o conselho de administração se manifestasse contrariamente à posição adotada pelo controlador em ofertas públicas.
} 
sequer na existência de um acionista controlador, nos termos do art. 116 da LSA.

Assim, frente à ausência de um acionista controlador e sendo verificada uma significativa passividade dos demais acionistas, passa a ser factível a transposição do poder de controle das mãos dos acionistas para a figura dos administradores ${ }^{12}$.

Diante deste cenário, ressurgiu um debate acerca de um tema cuja aplicabilidade ao direito brasileiro era até então vista como altamente improvável por grande parcela da doutrina ${ }^{13}$, qual seja, o controle gerencial.

Rotineiramente elencada na literatura jurídica nacional como uma modalidade do poder de controle, o controle gerencial diverge por inteiro das demais espécies até então delineadas no presente estudo, uma vez que não se funda no (e não é exercido por quem tem) direito de voto.

Considerando que o controle gerencial não é exercido por aquele que tem direitos de sócio, mas sim pelos administradores da companhia, cumpre, de início, ressaltar que, à luz da LSA a figura do "controlador" só se refere àquele que possui direitos de voto. Assim, pelo menos para fins estritamente técnico-jurídicos, nossa legislação societária não abarcou a figura o controle gerencial. Contudo, utilizaremos esse jargão jurídico, uma vez que se trata de termo comumente utilizado pela doutrina e que facilitará a leitura do presente trabalho. Feita esta breve ressalva, passaremos a analisar o instituto do controle gerencial.

O controle gerencial é passível de caracterização quando, em razão de um alto grau de dispersão acionária:

\footnotetext{
${ }^{12}$ Nas palavras de Renato Ventura Ribeiro: "as regras e a disseminação da cultura de governança corporativa, em especial no tocante à totalidade de ações com direito a voto e dispersão acionária, podem facilitar o controle gerencial, se persistir o absenteísmo dos acionistas. Até o momento a dinâmica capitalista foi estruturada para que pequenos acionistas não tenham ou não possam influir no controle das companhias. E a governança corporativa, apesar de seus benefícios, pode servir para legitimar o atual quadro do capitalismo" (RIBEIRO, Renato Ventura. Direito de Voto nas Sociedades Anônimas. São Paulo: Quartier Latin, 2009, p. 54).

${ }^{13}$ EIZIRIK, Nelson. O mito do "controle gerencial": alguns dados empíricos. Revista de Direito Mercantil, Industrial, Econômico e Financeiro. São Paulo: Malheiro, n. ${ }^{\circ}$ 66, p. 103-106, abr./jun., 1987.
} 
"não é possível identificar a formação de um núcleo decisório constante entre os acionistas e nas quais a tomada de decisões no âmbito da assembleia geral acontece de forma casuística, sendo geralmente orientada pela administração da companhia" ${ }^{14}$.

Em tais circunstâncias, a participação acionária deixa de ser o fundamento do poder de comando, que passa a se fundar nas prerrogativas dos administradores da companhia que serão aqueles que de fato controlarão a companhia.

O controle gerencial, mais especialmente, a possibilidade de sua existência no cenário nacional, é matéria que permanece dividindo a doutrina. Para alguns, a ocorrência de um controle gerencial nas companhias brasileiras não seria factível, pois, no máximo, o que se verificaria no atual cenário de dispersão acionária seriam minoritários que reunidos deteriam significativas parcelas dos votos ${ }^{15}$. Para outros, entretanto, seria impreciso afirmar a inexistência de companhias brasileiras que poderiam se caracterizar como controladas pela administração, uma vez que o controle gerencial pode decorrer não só da pulverização acionária, mas também da ausência de influência dos sócios sobre a administração ${ }^{16}$.

Em relação aos requisitos para configuração do controle gerencial, o que se deve deixar claro, desde já, é que:

“a despeito de a dispersão acionária ser condição necessária de materialização do controle gerencial, ela, por si só, não é suficiente. Isso porque, o que caracteriza o controle gerencial é a ausência de acionista ou grupo de acionistas que detenha direitos de sócio que lhe permitam prevalecer em conclaves sociais e, daí, influenciar as decisões sociais, ou, em havendo esses acionistas ou grupo de acionistas, seja verificada sua passividade. Dessa forma, afirma-se que a passividade dos acionistas é elemento essencial para a caracterização do controle

\footnotetext{
${ }^{14}$ MELLO, Carlos Barbosa e DE CARVALHO, André Ziccardi. Controle Difuso, Poison Pills e Hostile Take Over Bid. In. SIQUEIRA, Marcelo, PEREIRA, Atademes Branco e TREIGER, José Marcos. Brasil S/A: Guia de Acesso ao Mercado de Capitais para Companhias Brasileiras - Rio de Janeiro: RR Donnelley Financial Comunicação Corporativa, 2014. p. 158.

${ }^{15}$ AZEVEDO, Luís André N. de Moura. Ativismo dos Investidores Institucionais e Poder de Controle nas Companhias Abertas de Capital Pulverizado Brasileiras. In CASTRO, Rodrigo R. Monteiro de; - (Coord.). - Poder de Controle e Outros Temas de Direito Societário e Mercado de Capitais. São Paulo: Quartier Latin, 2010, p. 239.

${ }^{16}$ MACEDO, Ricardo Ferreira de. Controle Não Societário. Rio de Janeiro: Renovar, 2004, p. 135.
} 
gerencial, caso contrário, verificar-se-ia o exercício do controle por uma minoria atuante" $" 17$.

Cabe então indagar se de fato há companhias brasileiras que apresentem uma dispersão acionária tão significativa que faz com se impossibilite a existência ou visualização de um acionista controlador. Para tanto, elencamos alguns casos de acentuada dispersão acionária no mercado nacional:

\begin{tabular}{|c|c|c|}
\hline Companhia & $\begin{array}{l}\text { Free } \\
\text { float }\end{array}$ & $\begin{array}{l}\text { Maior Participação } \\
\text { Acionária Detida }^{18}\end{array}$ \\
\hline BR Malls Participações S.A. & $69,78 \%$ & $9,57 \%$ \\
\hline Cia Hering & $64,52 \%$ & $7,39 \%$ \\
\hline $\begin{array}{l}\text { CVC Brasil Operadora e Agência } \\
\text { de Viagens S.A. }\end{array}$ & $87,05 \%$ & $7,03 \%$ \\
\hline Estácio Participações S.A. & $81,79 \%$ & $10,48 \%$ \\
\hline Eternit S.A. & $66,07 \%$ & $14,60 \%$ \\
\hline Gafisa S.A. ${ }^{19}$ & $51,58 \%$ & $20,24 \%$ \\
\hline $\begin{array}{ll}\text { International Meal Company } \\
\text { Alimentação S.A. }\end{array}$ & $57,84 \%$ & $9,99 \%$ \\
\hline Kroton Educacional S.A. & $72,98 \%$ & $5,34 \%$ \\
\hline Liq. Participações S.A. & $73,85 \%$ & $16,43 \%$ \\
\hline Lojas Renner S.A. & $68,98 \%$ & $13,82 \%$ \\
\hline Qualicorp S.A. & $74,61 \%$ & $14,83 \%$ \\
\hline Totvs S.A. & $66,51 \%$ & $16,16 \%$ \\
\hline
\end{tabular}

${ }^{17}$ OLIVEIRA, Flávia Jardim de, e CARVALHO, Gabriela Cerqueira de. O Controle Gerencial e a Responsabilização do Administrador em Caso de Conflito de Interesses. São Paulo. Red GV. v. 01, n. 03, jul/2013, artigo 03, p. 48.

${ }^{18}$ Incluindo a participação acionária detida por um conjunto de acionistas em caso de acordo de acionistas.

${ }^{19}$ Em 2012, a pulverização acionária da Gafisa S.A. ficou tão alta que 99,54\% do seu capital social estava no free float. Na época, seus dois maiores acionistas detinham $0,07 \%$ e $0,25 \%$ do capital votante. Tais eram, respectivamente, os membros do conselho de administração e os diretores da companhia. Conforme formulário de referência entregue em 11 de julho de 2012. Acessível em http://siteempresas.bovespa.com.br/consbov/ExibeTodosDocumentosCVM.asp?CNPJ=01.545.826 10001-07\&CCVM=16101\&TipoDoc=C\&QtLinks=10. Acesso em 04.06.2018. 


\begin{tabular}{|l|l|l|}
\hline $\begin{array}{l}\text { Valid Soluções e serv. Seg. Meios } \\
\text { pag. Ident. S.A. }\end{array}$ & $78,77 \%$ & $10,13 \%$ \\
\hline
\end{tabular}

BM\&F Bovespa ${ }^{20}$

À luz do exposto acima, parece-nos difícil afirmar categoricamente que não se possa falar atualmente em companhias controladas por administradores. No caso da Gafisa S.A. em 2012 e da CVC atualmente, percebe-se que suas bases acionárias foram tão pulverizadas que seus maiores acionistas não chegavam a deter nem $10 \%$ do seu capital social, havendo free floats de mais de $88 \%$. Não à toa, informa Luís André N. de Moura Azevedo que "existem relatos de que algumas companhias listadas no Novo Mercado da Bolsa de Valores de São Paulo se encontrariam sob controle gerencial, ${ }^{21}$.

Acreditamos, assim, que apesar de casos esparsos, seria imprudente asseverar que indubitavelmente não haveria nenhuma companhia sob controle gerencial no mercado brasileiro. Tal conclusão, conforme já informamos, não está por defender de forma alguma o controle gerencial em detrimento das demais modalidades de poder de controle, nem de afirmar que a regra geral deixou de ser o controle majoritário. O que se quer com esta conclusão é informar que estes indícios são suficientes para impossibilitar a rejeição absoluta da possibilidade e ocorrência de companhias sob controle gerencial no mercado nacional.

Assim sendo, considerando a possibilidade ou até mesmo a existência de um controle gerencial é preciso que nos questionemos sobre quais seriam as potenciais problemáticas que dele possam advir e se o ordenamento jurídico brasileiro se encontra preparado para enfrentá-las.

\footnotetext{
${ }^{20}$ http://www.bmfbovespa.com.br/pt br/produtos/listados-a-vista-e-derivativos/rendavariavel/empresas-listadas.htm Acesso em 04.06.2018.

${ }^{21}$ AZEVEDO, Luís André N. de Moura. Controle Minoritário: Dissociação entre Voto e Participação Econômica na Companhia Aberta - Coleção IDSA de Direito Societário e Mercado de Capitais - Volume 8. São Paulo: Quartier Latin, 2017. p. 28.
} 


\section{CAPÍTULO 2. OS PROBLEMAS DECORRENTES DA ALTA DISPERSÃO ACIONÁRIA}

Inicialmente, cumpre destacar que o exercício do poder de controle por parte dos administradores traz ensejo a diversas situações de conflito de interesses (tema que trataremos especificamente mais adiante). Nessa seara, os estudiosos do direito societário brasileiro sempre separaram o instituto do conflito de interesses de maneira tríplice, de forma que haveria, na estrutura interna das companhias, a possibilidade de ocorrência de conflitos entre: (i) acionista controlador e acionista não controlador; (ii) acionistas e a companhia; e (iii) administradores e a companhia ${ }^{22}$.

Todavia, a ocorrência da pulverização da base acionária no mercado de capitais nacional tornou relevante outra forma de conflito de interesses, que até então se dava, de modo geral, uma menor importância, que seria aquela entre os acionistas e os administradores. Este tipo de conflito nunca foi relevante, uma vez que os administradores sempre foram vistos como pessoas colocadas na direção da companhia pelo acionista controlador e que por ele eram totalmente influenciadas. Porém:

"o aumento do número de companhias com o capital pulverizado em bolsa, notamos uma mudança gradativa, nestas companhias, do perfil do Conselho de Administração. De órgão formal, que se reunia esporadicamente para decidir conforme as orientações do acionista controlador, o Conselho de Administração passa a assumir as rédeas da administração e a impor a sua visão para os rumos da companhia. Na ausência de um único dono, o Conselho assume essa função, como representante dos acionistas, zelando pela condução dos negócios"²3.

Tal conjuntura de dissociação do poder de controle da propriedade acionária faz com que as decisões de caráter empresarial não sejam mais tomadas por aqueles que contribuíram patrimonialmente para o desenvolvimento da companhia (e que, consequentemente, são os que suportaram os riscos de um eventual fracasso), mas sim por aqueles que

\footnotetext{
${ }^{22}$ SADDI, Jairo. Conflito de Interesses no Mercado de Capitais. In CASTRO, Rodrigo R. Monteiro de; ARAGÃO, Leandro Santos de (Coord.). Sociedade Anônima. São Paulo: Quartier Latin, 2007, p. 348.

${ }^{23}$ SILVA, Carlos Alexandre Lobo e. A evolução da aquisição de controle de companhias abertas no Brasil. In: SILVA, Alexandre Couto [coordenador]. Direito societário. São Paulo: Saraiva, 2013. p. 249.
} 
conhecem a companhia e a administram, mas que não sofreram os riscos inerentes à atividade empresarial. Há entre acionistas e administradores, portanto, o que se chama de "relação de agência" que é aquela na qual alguém (principal) é titular de uma propriedade e delega a um terceiro (agente) a gestão desta propriedade e a capacidade de agir em seu nome para defender seus interesses.

Percebe-se, portanto, que a relação de agência no âmbito societário decorre de, de um lado, haver o acionista (principal), verdadeiro proprietário dos frutos daquele investimento, e, de outro, o administrador (agente) que exercerá poderes sobre algo que não é de sua propriedade ${ }^{24}$.

$\mathrm{O}$ acionista que realiza o investimento na grande maioria das vezes não tem a expertise e o tempo necessário para adequadamente maximizar seu investimento sem que se elevem os custos de transação ${ }^{25}$, e, por isso, delega esta tarefa ao administrador que, em nome do acionista, terá competência para realizá-la.

Assim, Jensen e Meckling ${ }^{26}$ identificaram que tal delegação de responsabilidades dos acionistas exigirá dos administradores esforços e tolerância a riscos que não serão necessariamente recompensados em sua integralidade. Tal fato acrescido da potencial divergência de interesses entre as partes da relação de agência acarretará em incentivos aos administradores a ignorar as responsabilidades a eles delegadas, utilizandose livremente de informações que detém para maximizar a sua própria riqueza, e não a dos acionistas. Dessa forma, sempre que os interesses das

\footnotetext{
${ }^{24}$ Destacamos, contudo, que a relação de agência não ocorrerá apenas na relação entre acionistas e administradores. A relação de agência ocorrerá sempre que alguém exercer um poder de gerência sobre algo que não lhe pertence. Assim, a relação de agência pode ser verificada na relação entre acionista controlador e não controlador, entre a companhia e seus credores, dentre outras possibilidades. A utilização do delineamento da relação de agência em conexão com a dispersão do capital acionário no presente trabalho se dá para fins meramente didáticos, sendo possível, portanto, a ocorrência de relações e custos de agência em qualquer estrutura acionária, seja ela concentrada ou diluída.

${ }^{25}$ Richard Posner conceitua os custos de transação como "os custos envolvidos em organizar a atividade econômica mediante trocas voluntárias" (POSNER, Richard A. Economic Analysis of Law. 6. ed. New York: Aspen, 2003, p. 407).

${ }^{26}$ JENSEN, Michael C.; e MECKLING, William H. Theory of the Firm: Managerial Behavior, Agency Costs and Ownership Structure. Journal of Financial Economics, October, 1976, v. 3, No. 4, pp. 305-360.
} 
partes de uma relação de agência não coincidirem integralmente haverão os chamados "conflitos de agência", nos quais o agente buscará maximizar seus próprios interesses em detrimento dos interesses do principal.

No cenário acima, surgem também as problemáticas da seleção adversa (adverse selection) e do risco moral (moral hazard).

Em razão da posição que ocupa o agente possuirá informações que o principal não partilha, possibilitando-se ao agente ocultá-la, de forma a optar, segundo por seus próprios riscos e interesses, em detrimento dos interesses do principal, pela contratação ou não de determinado produto ou serviço. George A. Akerlof ${ }^{27}$ exemplifica a questão através da venda de carros usados, nas quais uma parte sabe que existem os carros bons e os ruins. Um carro bom seria avaliado em $R \$ 15.000$ e um ruim por $R \$$ 10.000. Obviamente, o proprietário do carro terá informações necessárias para saber se o seu veículo é bom ou ruim. Por outro lado, o comprador não partilhará desta informação, e, portanto, correrá corre o risco de comprar um carro ruim. Dessa forma, o comprador não estará disposto a pagar um preço muito alto. Isso afetará a todo o mercado, pois os proprietários de carros bons não os venderão por preço mais baixo, e o mercado de carros acabará sendo dominado por carros de baixa qualidade.

Portanto, se todos estiverem tendo risco de comprar algo por um valor não adequado, em razão da assimetria informacional, não haverá quem compre. Percebe-se, consequentemente, que a divulgação das informações é fundamental a todos os participantes do mercado. Trazendo a questão para o âmbito societário, conclui-se que os acionistas demandarão que os administradores prestem diversas informações de forma a terem maior segurança de que a atuação dos administradores não está se dando para fins meramente pessoais.

O risco moral, a seu turno, ocorre quando o agente omite do proprietário informações relevantes, impossibilitando que este analise

\footnotetext{
27 AKERLOF, George. The Market for lemons: quality uncertanty and the market mechanism. Quarterly Journal of Economics, 84 (1970): 488-500.
} 
adequadamente a eficiência das atitudes do gestor e/ou os resultados destas. Difere-se da seleção adversa, pois se dá posteriormente à contratação. $\mathrm{O}$ caso clássico é o do seguro. Quando alguém adquire um veículo não segurado, é natural que este indivíduo dirija de maneira cautelosa, uma vez que arcará com os custos advindos de algum que acidente que dê causa. Ocorre, entretanto, que este mesmo indivíduo, a partir da contratação de um seguro, deixe de dirigir cautelosamente como antes fazia, pois os custos de uma eventual batida passarão a ser incorridos pela seguradora, não mais por ele.

No cenário de uma companhia, percebe-se que o motorista do carro segurado está para o administrador, assim como a seguradora está para o acionista. O administrador atuará sob riscos que não tomaria se fosse acionista, posto que temeria a perda do seu investimento. Tal prática não deve, entretanto, ser repreendida em qualquer caso. Como se sabe, os acionistas têm aversão ao risco (risk-averse), isto é, diante da incerteza, comportam-se de forma a reduzir esta incerteza. É o caso, por exemplo, de optar entre um investimento cujo resultado é mais previsível, mas que gerará um ganho menor do que em caso de sucesso de outro investimento cujo resultado é mais imprevisível. Ocorre, porém, que o sucesso no mundo empresarial exige a tomada de riscos e é por isto que as decisões muitas vezes são tomadas por quem não é proprietário daquele patrimônio, uma vez que se verá mais propenso a tomar decisões arriscadas, o que não significa, contudo, a aceitação de atitudes inconsequentes e irresponsáveis.

Assim, a assimetria informacional, no âmbito da relação de agência entre acionista e administrador, possibilita a ocorrência dos fenômenos da seleção adversa e do risco moral, podendo gerar prejuízos à companhia, aos seus acionistas, e a todos os seus stakeholders. Logo, os acionistas, a fim de ter maior certeza acerca da adequação da atuação dos administradores, tomarão medidas para alinhar os interesses das partes e fiscalizar os atos feitos pelo agente que, por não ter participação no capital social, poderão ser, em detrimento dos interesses dos acionistas, menos diligentes na gestão 
da empresa, tendo maior propensão para atribuírem regalias e recompensas excessivas a si mesmos.

Tais medidas resultarão nos custos de agência (agency costs) que são o conjunto de atos e sistemáticas utilizados para alinhar os interesses do agente aos dos proprietários ${ }^{28}$. Tratam-se, portanto, da soma dos custos: (i) incorridos pelo principal para monitorar os atos do agente; (ii) incorridos pelo agente para convencer o principal de que buscam atingir os objetivos contratados; e (iii) o equivalente monetário da redução do bem-estar vivenciada pelo principal devido a essa divergência (chamadas de perdas residuais) ${ }^{29}$.

Neste cenário de potenciais conflitos de agência, gerados a partir da relação acionista-administrador, surgem institutos jurídicos que buscam reduzir tais conflitos de forma a alinhar os interesses das partes. Dentre os diversos institutos utilizados, dois são de grande interesse ao presente estudo, quais sejam, (i) os deveres fiduciários dos administradores (em especial os deveres de diligência e lealdade) e (ii) as tomadas hostis de controle. Passaremos agora à análise destes institutos.

\footnotetext{
28 JENSEN, Michael C.; e MECKLING, William H. Theory of the Firm: Managerial Behavior, Agency Costs and Ownership Structure. Journal of Financial Economics, October, 1976, V. 3, No. 4, p. 310.

${ }^{29}$ JENSEN, Michael C.; e MECKLING, William H. Ibid., p. 311.
} 


\section{CAPÍTULO 3. DOS DEVERES FIDUCIÁRIOS}

Em face dos custos de transação e racionalidade limitada, não se torna possível aos acionistas celebrar um pacto social no qual sejam integralmente previstas todas as soluções para cada tipo de situação ${ }^{30}$. Se assim o fosse, não haveria necessidade alguma de se estabelecer quaisquer tipos de deveres fiduciários ${ }^{31}$.

Assim, os administradores, que têm por objetivo a exploração do objeto social para geração e distribuição dos lucros aos seus acionistas, deparam-se com diversas situações, cujos caminhos e modos de agir não estão, em sua esmagadora maioria, preestabelecidos no estatuto social. Dessa forma, a fim de resolver tal problemática, três soluções podem ser apresentadas.

A primeira seria permitir que os administradores pudessem livremente, sem qualquer tipo de restrição, parâmetro ou balizamento, tomar qualquer tipo de decisão acerca de matérias de sua competência, sem que pudessem ser responsabilizados por quaisquer danos gerados à companhia ou aos seus acionistas. Tal solução, por óbvio não foi a escolhida, pois, se assim fosse, os acionistas estariam a total mercê dos administradores por mais estapafúrdias, irresponsáveis e inconsequentes que fossem suas escolhas.

No polo oposto, poder-se-ia solucionar este problema exigindo que toda e qualquer decisão da administração tivesse que necessariamente ser referendada pela assembleia geral ou que fossem estipulados contratos sociais extremamente detalhados. Isto, também por óbvio, não foi optado, uma vez que engessaria por completa a atuação dos administradores, extinguindo integralmente sua discricionariedade.

\footnotetext{
${ }^{30}$ PARGENDLER, Mariana. Modes of gap filling: good Faith and fiduciary duties reconsidered. Tulane Law Review, v. 82, 2008. p. 11

31 EASTERBROOK, Frank; FISCHEL, Daniel. The economic structure of corporate law. Cambridge, Mass.: Harvard University Press, 1991. p. 90.
} 
Desse modo, optou-se por uma alternativa intermediária. Permitiu-se aos gestores uma certa margem de discricionariedade para que atuem no interesse da companhia, porém, estabeleceu-se, para tanto, balizadores de comportamento, instrumentos que buscam preencher os vazios constantes do pacto social. Tratam-se de formulações abstratas e genéricas que consubstanciam padrões comportamentais e que dão ao intérprete da lei uma mobilidade hermenêutica.

Dessa forma, os administradores que atuarem dentro dos padrões estabelecidos por estes standards comportamentais, poderão buscar a maximização do patrimônio da companhia, e, por conseguinte, dos seus acionistas, sem temer qualquer tipo de responsabilização. Os acionistas, por outro lado, saberão o que esperar da conduta dos administradores não precisando monitorar todos os seus atos. Assim sendo, percebe-se que os deveres fiduciários buscarão alinhar os interesses das partes desta relação de agência, gerando, consequentemente, a redução dos custos de agência.

Estes standards de comportamento não são os mesmos referentes ao "homem médio", mas sim "uma ideia comum de racionalidade, lealdade, ou justiça, envolvendo, de certa forma, um julgamento moral sobre determinado comportamento. Por tais motivos, devem os padrões de conduta encontrar uma aplicação variável conforme o tempo, o lugar e as circunstâncias, devendo ser empregados conforme as peculiaridades de cada caso $^{, 32}$.

Dessa maneira, os deveres fiduciários funcionam, conforme já mencionado, como instrumentos de alinhamento de interesse na relação de agência. Como vimos, o agente gere algo que pertence a outrem, o principal, e, por isso, possui mais informações que o principal. Tal fato faz com que sejam gerados os problemas da seleção adversa e risco moral. A fim de se evitar que o administrador use da sua posição privilegiada para obter vantagens pessoais indevidas, criam-se os deveres fiduciários, pois,

\footnotetext{
${ }^{32}$ PARENTE, Flávia. O dever de diligência dos administradores de sociedades anônimas. Rio de. Janeiro: Renovar, 2005. p. 34.
} 
essa desequilibrada relação jurídica exige que ao agente seja imposto algo além do mero dever contratual de padrão de boa-fé ordinária. Requer-se do agente, portanto, a observância de um dever de extrema boa-fé, em outras palavras, exige-se deste uma atuação na persecução dos melhores interesses do principal, como se estivesse agindo para si próprio ${ }^{33}$.

Os deveres fiduciários são, portanto, cláusulas gerais, cuja aplicação, extensão e interpretação dependerão da análise do caso concreto, sem que $a$ priori sejam determinadas as condutas devidas. Assim, esta análise casuística deverá levar em conta diversos aspectos do caso concreto, como, por exemplo, (i) a extensão das obrigações dos administradores, (ii) sua respectiva responsabilidade, (iii) o órgão que este integre e suas atribuições, (iv) a área em que desempenha sua atividade, (v) o porte da companhia, (vi) a situação econômico-financeira da companhia, (vii) a relevância da empresa perante a comunidade, (viii) o impacto social, econômico e ambiental da atividade, (ix) o momento da tomada da decisão, (x) as informações então disponíveis, (xi) eventuais pressões externas e internas, (xii) se o administrador se dedica integralmente ou não àquela companhia, (xiii) se ele é e como é remunerado para exercer tal atividade, e (xiv) se sua saúde física ou mental influenciou sua maneiro de atuar, dentre outros.

Em relação à sua previsão legal, os deveres fiduciários estão positivados nos arts. 153 a 159 da LSA, e são devidos, nos termos do art. 145 da $\operatorname{LSA}^{34}$, a todos os membros dos órgãos da administração (conselho de administração, conselho fiscal e diretoria), e se dividem em três espécies principais: (i) dever de diligência, (ii) dever de lealdade; e (iii) dever de obediência. Destas três analisaremos as duas primeiras que são as que se reputam relevantes para o objeto do presente estudo.

\footnotetext{
${ }^{33}$ YAZBEK, Otávio. Regulação do Mercado Financeiro e de Capitais. Rio de Janeiro: Elsevier, 2009. p. 43-44.; POSNER, Richard. Economic Analysis of Law. $6^{\mathrm{a}}$ ed. New York: Aspen Publisher, 2003, p. 114.

${ }^{34}$ Art. 145. As normas relativas a requisitos, impedimentos, investidura, remuneração, deveres e responsabilidade dos administradores aplicam-se a conselheiros e diretores.
} 
Iniciaremos agora uma breve análise destas duas espécies de deveres fiduciários a fim entendermos a forma pelas quais estes deveres se aplicam aos membros do conselho de administração quando em face de uma tentativa de tomada hostil de controle.

\subsection{Dever de Diligência}

O legislador pátrio inseriu o dever de diligência no art. 153, LSA. Vejamos seu teor:

"Art. 153. O administrador da companhia deve empregar, no exercício de suas funções, o cuidado e diligência que todo homem ativo e probo costuma empregar na administração dos seus próprios negócios."

Este dever fiduciário está vinculado, portanto, ao esforço ou zelo para cumprir as funções incumbidas à administração ${ }^{35}$. Abarca o dever de diligência um referencial pragmático, isto é, uma conduta determinada ligada a uma atividade ou a um standard comportamental ${ }^{36}$, através do qual se analisa o caso concreto para que se verifique se o administrador, no exercício de suas funções, cumpriu com o que dele se esperava ou não. Percebe-se, portanto, que o dever de diligência, enquanto espécie de dever fiduciário, não tem conteúdo delimitado em lei, visto que esta apenas tipifica genericamente as condutas a serem seguidas pelo administrador, quando do exercício de suas funções, de forma a proteger os interesses da companhia e seus acionistas ${ }^{37}$.

\footnotetext{
${ }^{35}$ JORGE, Fernando de Sandy Lopes Pessoa. Ensaio sobre os Pressupostos da Responsabilidade Civil. Coimbra: Almedina, 1999. p.75.

${ }^{36}$ CASTRO, Flávia de Almeida de Viveiros de. O modelo do bom pai de família e a responsabilidade civil contratual: Origens e Desdobramentos. Direito, Estado e Sociedade. Rio de Janeiro, n.15, p.17, ago./dez., 1999.

37 Conforme voto da ex-diretora da CVM, Norma Parente, no Processo Administrativo Sancionador CVM n. ${ }^{\circ}$ 04/9928: "a lei estabelece que o administrador deve empregar no exercício de suas funções o cuidado que todo homem ativo e probo costuma usar na administração de seus próprios negócios. O texto é bastante claro e dispensa qualquer regulamentação. Assim, não é verdade que o 'standard' jurídico não pode ser aplicado enquanto não for regulamentado. $\mathrm{Na}$ verdade, o 'standard' indica uma conduta abrangente aceita pela sociedade, reconhecido pela lei e independe de qualquer regulamentação. $O$ seu desrespeito, portanto, representa uma ilegalidade (...)".
} 
O legislador, tradicionalmente, quando da positivação de standards comportamentais, utilizou-se do princípio do bonus pater familias, por meio do qual se exigia do administrador um comportamento tal qual o do "bom pai de família". Ocorre, entretanto, que tal princípio se baseava no Código Comercial brasileiro, de 1850 , cujo art. $142^{38}$ equiparava a figura do administrador à do mandatário. Tal comparação, por óbvio, reputa-se equivocada, visto que a adoção da teoria organicista sedimentou que o administrador não é mandatário, mas sim órgão da companhia ${ }^{39}$.

Foi dessa maneira, que se superou a utilização do princípio do bonus pater familias, já que o bom pai de família visa agir para preservar o patrimônio familiar. Isto, por óbvio, não é aceito no cenário empresarial, pois nele se exige dos administradores a busca pela maximização da riqueza da companhia, e, para tanto, é necessária a assunção de riscos na gerência e orientação dos negócios sociais, uma vez que, conforme supramencionado, o sucesso da atividade empresarial requer a tomada de riscos.

Em razão da consciência dessa necessidade econômica de assumir riscos, os países mais desenvolvidos se viram obrigados a adotar medidas que, de um lado, balizassem a atuação dos administradores, mas que, por outro lado, não engessasse sua atuação. Nessa esteira, foi o direito norteamericano que surgiu como pioneiro e maior contribuinte para o desenvolvimento dos deveres fiduciários, dentre eles: o dever de diligência (duty of care) e o dever de lealdade (duty of loyalty).

Foi assim que a jurisprudência norte-americana, maior fonte jurídica do país, decompôs o dever de diligência nos seguintes aspectos: (i) o dever de se qualificar para o exercício do cargo; (ii) o dever de bem administrar; (iii) o dever de se informar; (iv) o dever de investigar; e (v) o dever de vigiar.

\footnotetext{
38 Art. 142 - Aceito o mandato, o mandatário é obrigado a cumpri-lo segundo as ordens e instruções do comitente; empregando na sua execução a mesma diligência que qualquer comerciante ativo e probo costuma empregar na gerência dos seus próprios negócios.

${ }^{39}$ LAMY FILHO, Alfredo; PEDREIRA, José Luiz Bulhões (Coord.). Direito das companhias. 2.ed. atual. refor. Rio de Janeiro: GEN, Forense, 2017, p. 563.
} 
Em relação a estes cinco aspectos que compõe o dever de diligência, é preciso deixar claro que eles devem ser utilizados meramente como instrumento de aferição da responsabilidade dos atos dos administradores à luz do caso concreto, avaliando-se, com isso, se a conduta adotada se coaduna com a atitude recomendável, em tal circunstância, naquele ramo empresarial, em concordância com as regras da ciência da administração de empresas $^{40}$.

Forçoso também se faz ressaltar que o cumprimento do dever de diligência não é sinônimo de sucesso. Consequentemente, infere-se que o dever de diligência, se cumprido, não é apto per si de obstar o administrador do equívoco. O óbice gerado pelo dever de diligência, sendo preenchidos os requisitos mais adiante analisados, relaciona-se à imputação da responsabilidade pelos efeitos da atitude do administrador à sua pessoa. Assim, os danos causados pela mera má fortuna do negócio não podem ser irrestritamente imputados ao administrador.

Feitas estas breves ressalvas preliminares e à luz da segmentação do dever de diligência acima aludida, passaremos a desenvolver cada um dos cinco aspectos do dever de diligência.

O primeiro aspecto é o dever de se qualificar. Este exige do administrador os conhecimentos técnicos necessários para o desenvolvimento das atividades integrantes do objeto social a serem por ele exercidas em nome da sociedade.

A seu turno, o dever de bem administrar requer que a conduta do administrador se dê dentro dos limites estabelecidos no objeto social e que seja voltada para a consecução do interesse social. Em relação a este ponto, cumpre esclarecer que, conforme já mencionado, o sucesso, o lucro, objetivo intrínseco e característico das sociedades por ações, não é imprescindível para fins de cumprimento do dever de diligência, visto ter

${ }^{40}$ EIZIRIK, Nelson; GAAL, Ariádna B; Parente, Flávia; HENRIQUE, Marcus de Freitas. Mercado de capitais - regime jurídico. 3.ed. revista e ampliada. - Rio de Janeiro: Renovar, 2011, p. 410. 
natureza de mera obrigação de meio. Dessa forma, o que o administrador deve necessariamente apresentar é um comportamento diligente, limitado às atividades previstas no estatuto social da companhia (em especial no que se refere ao seu objeto social) e na legislação aplicável.

Entretanto, não basta ser competente, capaz e agir dentro do limite do estatuto social e da lei perseguindo o interesse social, é preciso também que o administrador possua todas as informações necessárias para gerir os negócios sociais, o que será exigido pelo dever de se informar. Este, por sua vez, não poderá ser interpretado de forma excessiva, de forma a exigir do administrador ciência de todas e quaisquer informações sobre os negócios da companhia. Para tanto, a análise deve ser sempre feita à luz dos princípios da proporcionalidade e razoabilidade. Não será, portanto, toda e qualquer matéria que exigirá uma análise minuciosa por parte do administrador. Entretanto, quando deparado com matérias sensíveis que possam ter significativos desdobramentos para a companhia e seus acionistas, exigir-se-á dos administradores uma análise aprofundada e cautelosa acerca dos "red flags" (situações que devam despertar um estado de alerta). Em tais situações, deverão os administradores investigar as informações disponibilizadas pelos demais órgãos sociais, a fim de verificar a integralidade, conformidade e legalidade das informações apresentadas.

Como último aspecto, há o dever de fiscalizar, segundo o qual os administradores deverão fiscalizar o andamento das atividades sociais. Em outras palavras, o administrador deve fiscalizar e controlar as atividades desenvolvidas por seus subordinados diretos e indiretos, além da necessidade de contratação de funcionários tecnicamente aptos.

Elucidado os elementos que definem e subdividem o dever de diligência, faz-se preciso disciplinar como, em cada caso concreto, afere-se o cumprimento ou não deste dever fiduciário.

Conforme mencionamos, o risco é inerente ao sucesso no âmbito empresarial, devendo, consequentemente, ser estimulado. Assim, 
considerando que o cumprimento do dever de diligência não gera certeza de sucesso, mas que o sucesso pressupõe a tomada de riscos, percebeu-se que seria economicamente vantajoso para todos os participantes do mercado que os administradores fossem estimulados a tomar riscos. Para tanto, fez-se necessário o desenvolvimento de uma regra que estabelecesse requisitos que, se preenchidos, blindariam o administrador da imputação de eventuais danos causados por seus atos, estimulando, por conseguinte, decisões arriscadas com fins de maximização da riqueza.

Foi assim que se desenvolveu na jurisprudência estadunidense o instituto da business judgment rule, cuja aplicabilidade ao nosso direito societário já é amplamente reconhecida no meio jurídico brasileiro, inclusive pela própria $\mathrm{CVM}^{41}$.

Passaremos agora a uma breve análise deste instituto.

\subsubsection{Business Judgment Rule}

A business judgment rule é, em resumo, uma regra que estabelece uma presunção juris tantum de que as decisões tomadas pelo administrador se deram (i) de boa-fé, (ii) de maneira diligente e (iii) exclusivamente voltadas para o interesse da companhia. Trata-se, portanto, como já informamos, de um mecanismo de estímulo e proteção aos administradores cujas funções exigirão audácia e tomadas de risco.

Busca-se através desta regra evitar que um administrador diligente possa responder pelos efeitos negativos oriundos de suas decisões. A ratio por trás desta regra é, portanto, o entendimento universal de que cabe ao mercado "corrigir erros reiterados de julgamento da administração, quando tomados de boa-fé, e no que era percebido pela administração da

\footnotetext{
${ }^{41}$ PAS RJ2005/1443, Dir. Rel. Pedro Oliva Marcilio de Sousa, julgado em 21/03/2006.
} 
companhia como o melhor para esta" ${ }^{\natural 2}$, e que sem tal proteção, o próprio mercado encontrar-se-ia desestimulado.

Assim, preenchidos determinados requisitos, será conferida tal presunção, impossibilitando-se a análise do mérito da decisão tomada pelo administrador e transferindo a quem conteste sua conduta o ônus de provar que os elementos e pressupostos da regra não foram atendidos. Desse modo, caso este não tenha sucesso em comprovar tal violação, a presunção restará íntegra, obstando a imputação de qualquer prejuízo resultante da decisão tomada à figura do administrador. Caso contrário, isto é, na hipótese de aquele que conteste a decisão tomada pelo administrador conseguir comprovar a violação de quaisquer dos requisitos, impossibilita-se a aplicação da business judgment rule, afastando-se, consequentemente, apenas a presunção que a regra confere. Em outras palavras, a impossibilidade de se aplicar a business judgment rule não acarreta, per si, na responsabilidade do administrador, gerando tão somente a possibilidade de se adentrar na análise do mérito da decisão tomada pelo administrador. Trata-se, com isso, de uma questão prejudicial que aquele que contesta deverá superar para possibilitar uma eventual responsabilização do administrador.

Conforme mencionado, a presunção conferida pela regra tem natureza juris tantum, logo, a proteção que a business judgment rule confere não é, por óbvio, irrestrita e absoluta, de forma a abarcar todas e quaisquer decisões. Se assim o fosse, os administradores não seriam estimulados a previamente analisar a fundo seus atos e, consequentemente, todo o mercado sairia prejudicado. Logo, cumpre discorrer sobre os elementos necessários para a possibilidade de aplicação da business judgment rule.

Em primeiro lugar, esclarece-se que só há que se falar em business judgment rule se efetivamente ocorrer uma decisão de caráter negocial. $\mathrm{Ou}$

42 BENSAL, Bruno Marques. A Business Judgment Rule no Direito Brasileiro: da Responsabilidade dos Administradores na Perspectiva do Direito Comparado e na Jurisprudência da CVM. Revista De Direito Empresarial | Vol. 7/2015 |P. 111 - 131| Jan - Fev / 2015. 
seja, a decisão tomada deve ter se dado em razão do cargo ocupado pelo administrador e exigir que este de fato tenha tomado alguma ação, ainda que no sentido de decidir por não agir.

A business judgment rule também só terá lugar quando a decisão tomada tiver sido cumulativamente desinteressada e independente. Dessa forma, compreende-se por desinteressado o administrador que não tenha interesses de caráter pessoal relacionados aos resultados e efeitos que possam ou venham a advir da decisão ${ }^{43}$. Desse modo, a business judgment rule não poderá ser arguida pelo administrador que tenha agido em conflito de interesses, tema que será tratado no momento oportuno.

A independência, por sua vez, caracteriza-se por ausência de influências externas. Nesse caso, será considerado independente o administrador que tenha atuado exclusivamente em prol do interesse social que não necessariamente coincide com os dos seus acionistas.

Ademais, é preciso esclarecer que, não só a proteção a ser dada pela business judgment rule não poderá abranger decisões irracionais ou oriundas da quebra do dever de lealdade, nem atos fraudulentos, ilegais ou ultra vires (atos que extrapolam as competências do autor do ato), como também exigirá (i) a presença de boa-fét4, (ii) cumprimento do dever de diligência $^{45}$, e (iii) adequação entre a decisão tomada e os interesses da companhia.

À luz do exposto acima, conclui-se que, ocorrendo danos causados por atos do administrador, estando preenchidos os requisitos acima e não

\footnotetext{
${ }^{43}$ Pogostin v. Rice (480 A.2d 619, 1984): "Directional interest exists whenever divided loyalties are present, or a director either has received, or is entitled to receive, a personal financial benefit from the challenged transaction which is not equally shared by the stockholders".

${ }^{44}$ A boa-fé impõe que o administrador aja de forma honesta e justa, verdadeiramente acreditando que sua decisão visava atingir os interesses sociais, sendo necessária para comprovação de sua violação, a presença e a particularização de provas cabais. BRIGAGÃO, Pedro Henrique Castello. A Business Judgment Rule no Direito Brasileiro: A Problemática da Recepção da Regra pela Lei das S.A. Revista de Direito Bancário e do Mercado de Capitais | vol. 74/2016 | Out - Dez / 2016. p. 106.

${ }^{45} \mathrm{O}$ cumprimento do dever de diligência ocorrerá quando os administradores tomem suas decisões com base nos fatos e informações relevantes e cujo acesso seja razoavelmente possível. Assim, a jurisprudência norte-americana se consolidou no sentido de que somente ocorrerá a violação ao dever de diligência nos casos de negligência grave (gross negligence), não bastando a mera culpa.
} 
ocorrendo irracionalidades, quebras do dever de lealdade ou atos fraudulentos, ilegais ou praticados fora da competência do administrador, surge a business judgment rule para impossibilitar a imputação de responsabilidades a tal administrador ${ }^{46}$, cabendo, consequentemente, àquele que conteste a decisão tomada provar o descumprimento de quaisquer destes requisitos.

No que tange à business judgment rule, a grande questão que surge da sua aplicação no ordenamento jurídico brasileiro é relativa à sua importação. Em outras palavras, discute-se onde tal regra está positivada em nosso ordenamento. Assim, apresentaremos um breve panorama geral acerca de tal debate, expondo as diversas opiniões existentes de forma a melhor esclarecer a questão.

De início, cumpre destacar que pela própria essência da business judgment rule, pode-se constatar que tal instituto não se trata de uma mera complexa construção jurídica, mas sim de simples e objetiva tradução do bom senso econômico do homem minimamente envolvido com a atividade empresarial. Em outros termos, não se faz necessário importar uma regra estrangeira, tal qual a business judgment rule, para inculcar em nosso judiciário e agentes reguladores a ideia de que não se pode atribuir aos administradores uma responsabilidade de caráter ilimitado. É preciso, para o bem do desenvolvimento econômico, que se atente aos elementos de atuação daquele que gere patrimônio alheio a fim de maximizá-lo.

Tal ideal já se encontra naturalmente presente no intelecto dos players do mercado. Há, assim, um senso comum, lastreado nos benefícios econômicos oriundos da assunção de riscos, de que (apenas) aos administradores que atuem em consonância com a lei, o estatuto social, o interesse social e os melhores padrões de diligência não devem ser imputadas eventuais perdas que acarretem em prejuízos às suas companhias causadas por suas decisões de viés negocial.

\footnotetext{
${ }^{46}$ CINTRA, Antonio Carlos Fontes. Responsabilidade dos Administradores Perante a Má Fortuna do Negócio e a Business Judgment Rule. Revista de Direito Bancário e do Mercado de Capitais | vol. 58/2012 | Out / 2012 p. 54.
} 
Nesse sentido, percebe-se que não há discordância quanto ao benefício trazido pela business judgment rule. Assim sendo, a problemática reside em sua aplicação e sua localização no ordenamento jurídico brasileiro. Foi a fim de resolver tal questão que ao longo dos tempos foram tomados diversos posicionamentos no cenário jurídico.

O primeiro dos entendimentos defendidos foi o adotado por autores como Nelson Eizirik ${ }^{47}$, José Waldecy Lucena ${ }^{48}$, João Pedro Barroso do Nascimento $^{49}$ e Alexandre Couto e Silva ${ }^{50}$ para quem a business judgment rule estaria positivada art. $159, \S 6^{\circ}$ da LSA que determina que o "juiz poderá reconhecer a exclusão da responsabilidade do administrador, se convencido de que este agiu de boa-fé e visando ao interesse da companhia".

Dessa forma, para os adeptos desse entendimento, a business judgment rule teria sido inteiramente incorporada, sem qualquer alteração, à nossa ordem jurídica através do dispositivo transcrito acima. Tratar-se-ia, por conseguinte, de uma tradução quase que perfeita da regra construída pela jurisprudência norte-americana.

Ocorre, entretanto, que, tal posição não se coaduna com a realidade, em vista das diversas diferenças que existem entre a business judgment rule e a norma do $\$ 6^{\circ}$ do art. 159 da LSA.

À título de ilustração, pode-se, de início, destacar em termos meramente formais que diferentemente da business judgment rule, que foi originada via jurisprudência, a norma do $\S 6^{\circ}$ do dispositivo supramencionado está positivada em lei.

\footnotetext{
${ }^{47}$ EIZIRIK, Nelson. A Lei das S/A comentada. Volume III (arts. 138 a 205). São Paulo: Quartier Latin, 2015.

${ }^{48}$ LUCENA, José Waldecy. Das sociedades anônimas - comentários à lei (arts. 121 a 188), v.2. Rio de Janeiro: Renovar.

${ }^{49}$ NASCIMENTO, João Pedro Barroso do. In: Direito societário: estudos sobre a Lei de Sociedades por Ações. São Paulo: Saraiva, 2013.

${ }^{50}$ SILVA, Alexandre Couto. Responsabilidade dos Administradores de S/A: business judgement rule. Rio de Janeiro: Elsevier, 2007
} 
Em seguida, pode-se também inferir que, quando comparadas, visualiza-se uma manifesta inversão do procedimento gerado pelas normas. Em outras palavras, de um lado, temos que a business judgment rule na ual se gera uma presunção de que a decisão tomada pela administrador se deu de boa-fé e no mesmo sentido do interesse social, impondo àqueles que contestem a decisão tomada o ônus de comprovar que tal decisão se deu em violação aos deveres fiduciários que o administrador deve observar.

Por sua vez, a regra contida no art. 159, $\S 6^{\circ}$ da LSA, é diametralmente inversa. Nela não se atribui qualquer tipo de presunção que obste a análise do mérito da decisão tomada. O que se confere por meio dela é uma ampla e exacerbada faculdade ao julgador para dispensar do administrador a obrigação de indenizar. Inverte-se o procedimento, pois enquanto na business judgment rule a proteção vem do início, no dispositivo da LSA ora em comento a imputação de responsabilidade resta afastada ao final.

Ou seja, o que há de comum é que, quando utilizadas em benefício do administrador, a este não será imputado qualquer dever de indenizar. Contudo, as regras são diversas quando de seu afastamento. Enquanto a business judgment rule, quando afastada, apenas permite ao julgador analisar o mérito da decisão tomada, para, então, aferir se no caso concreto a atuação do administrador gerará ou não a este o dever de indenizar a companhia pelos prejuízos causados pela sua decisão, a regra do $\S 6^{\circ}$ do art. 159, LSA, não obsta a análise do mérito da decisão adotada, mas sim permite ao julgador (diferentemente da business judgment rule que obriga o julgador) a dispensar o administrador do dever de indenizar.

Ademais, uma interpretação literal do art. 159, $\S^{\circ}$ da LSA possibilitaria ao julgador um amplo e desmedido campo de aplicação, uma vez que não disciplina se casos de conflito de interesses poderão ou não ser protegidos pela regra, enquanto a business judgment rule reconhecidamente não isenta de responsabilidade os administradores em situação de conflito de interesses. 
Tal indevida amplitude, todavia, não se esgota. A norma inserida no art. $159, \S 6^{\circ}$, LSA se refere de maneira genérica a "administradores", o que abrangerá não só os membros do conselho de administração, como também aqueles que integrem a diretoria e o conselho fiscal, enquanto que, conforme se nota no próprio direito norte-americano, há uma profunda incerteza quanto à possibilidade de utilização da business judgment rule no que se refere aos diretores (officers)".

Assim, discordando da vertente que entendia pela integral importação da business judgment rule, em vista das inconsistências existentes quando da comparação da business judgment rule com o $§ 6^{\circ}$ do art. 159 da LSA, veio a corrente sustentada por juristas como Marina Pargdendler" ${ }^{51}$, para quem o art. $159, \S 6^{\circ}$, LSA seria uma "tropicalização",52 da construção jurisprudencial norte-americana. Assim, nosso legislador teria compreendido o conceito da business judgment rule, concordado com a ideia nela contida, mas decidiu realizar algumas alterações tornando-a mais “à brasileira”. Infelizmente, também não podemos concordar com essa visão, visto que, conforme abordaremos adiante, são muitas as diferenças que separam a business judgment rule da norma inserta no $\S 6^{\circ}$ do art. 159 , LSA.

Sabe-se que para que possa ser aplicada a business judgment rule é necessário que haja uma decisão (i) de caráter negocial, (ii) efetiva, (iii) informada, (iv) refletida, (v) desinteressada, (vi) de boa-fé e (vii) de acordo com o interesse social. Observando a regra contida no art. $159, \S 6^{\circ}$, é fácil constatar que o legislador, a fim de permitir a exclusão da responsabilidade do administrador, somente levou em consideração os dois últimos elementos, ignorando por completo os demais, uma vez que, para autorizar

\footnotetext{
${ }^{51}$ PARGENDLER, Mariana. Responsabilidade Civil dos Administradores e Business Judgment Rule no Direito Brasileiro. Revista dos Tribunais | vol. 953/2015 | Mar / 2015| p. 63

52 Afirma-se no PAS CVM No 03/02 que: "E vai além, ainda, a Lei n 6.404/76, que numa 'tropicalização' da business judgment rule permite inclusive que se exclua a responsabilidade dos administradores, quando se verificar que estes mesmo violando a lei agiram de boa-fé e no interesse da companhia, conforme diz expressamente o parágrafo $6^{\circ}$ do art. $159^{\prime \prime}$
} 
o julgador a dispensar a responsabilidade do administrador, exige-se apenas que o julgador esteja convencido de que tal administrador agiu de boa-fé e visando atingir o interesse da companhia.

Assim, referido dispositivo somente fala em boa-fé e de atuação no interesse da companhia, simplesmente ignorando os demais requisitos obrigatórios para que seja conferida a proteção gerada pela business judgment rule.

O que pode parecer ser irrelevante, no entanto, não o é. A aberrante diferença entre as normas faz com que, em tese, um administrador possa ter sua responsabilidade afastada caso tenha simplesmente agido de boa-fé e de acordo com o interesse social. Em outras palavras, um administrador que tenha violado todos os seus deveres de diligência acima delineados, mas que tenha atuado de boa-fé e no interesse social, poderá ter sua responsabilidade afastada no caso concreto pela mera discricionariedade do juiz.

Observa-se, então, uma clara incoerência com o principal propósito da business judgment rule, qual seja, a proteção exclusiva daqueles administradores que buscam agir consoante os mais elevados padrões de diligência.

Essa interpretação passa a ser bastante prejudicial e preocupante, pois gera um descabido alargamento da business judgment rule, uma vez que, para que seja conferida a faculdade prevista no art. 159, §6 $6^{\circ}$ LSA, sequer se faz necessário o cumprimento do dever de diligência, bastando que o administrador tenha agido de boa-fé e no interesse social da companhia.

Ao desconsiderar a análise do cumprimento ou não dos deveres de diligência, extingue-se a razão de ser da business judgment rule, isto é, de proteger apenas aqueles administradores que agem de acordo com os padrões de comportamento e diligência próprios de seu cargo. A business judgment rule, a fim de cumprir o seu fundamento econômico, não pode ser um cheque em branco para os administradores, mas sim um instrumento de 
proteção e até mesmo de valorização dos profissionais da área, servindo, inclusive, de seletor natural no mercado acionário, já que apenas os mais diligentes não serão punidos e, consequentemente, permanecerão atuando.

Ocorre, contudo, que não só os administradores que tenham violado seus deveres de diligência poderão ter sua responsabilidade afastada. A literalidade da norma do art. $159, \S 6^{\circ}$ da LSA permite que o absurdo vá além. Ao exigir somente os dois requisitos acima elencados (boa-fé e atendimento ao interesse social), o dispositivo em comento permite que o administrador não seja punido mesmo que sua decisão tenha sido manifestamente irracional ou que tenha se dado fora das atribuições a ele conferidas por lei ou pelo estatuto social.

E não é só. O silêncio eloquente deixado por tal dispositivo também possibilita que os administradores tenham sua responsabilidade excluída ainda que tenham atuado culposamente, ou seja, atos negligentes podem ser relevados caso não haja violação à boa-fé ou ao interesse social.

Além disso, a norma do dispositivo em comento pressupõe, para que seja aplicada, que haja responsabilidade por parte do administrador. Em outras palavras, o legislador brasileiro alocou nas mãos do julgador a decisão de, no caso concreto e observados os dois requisitos ali determinados, excluir do administrador o dever de indenizar a companhia pelos prejuízos causados. Tal faculdade tem, portanto, um caráter excepcional, uma vez que dependerá de um juízo discricionário do julgador quando da análise do caso concreto, gerando, por consequência, uma forte insegurança jurídica, algo que a business judgment rule busca combater.

Há, assim, uma clara inversão de fatores em relação ao que preceitua a business judgment rule. Como visto, tal regra gera uma presunção de que o administrador estará sempre agindo no melhor interesse da companhia e de acordo com a devida diligência, fazendo com que o administrador que tenha cumprido com esses deveres e prerrogativas, próprias de sua função, não possa ser responsabilizado pelos danos oriundos de uma decisão negocial por ele tomada. Dessa forma, somente haverá responsabilização 
se, depois de afastada a business judgment rule, em razão do descumprimento de algum dos seus requisitos, verificar-se durante o processo cognitivo a existência de um dano injusto que tenha nexo de causalidade com a decisão tomada pelo administrador ou que tal decisão tenha se dado em violação às normas legais e/ou estatutárias.

À luz do exposto acima, fica evidente que as diferenças existentes entre o art. $159, \S 6^{\circ}$ da LSA e a ratio da business judgment rule. Portanto, entender que a regra está positivada em tal dispositivo da LSA é, de certa forma, um grave empecilho à correta aplicação da business judgment rule no direito brasileiro e à geração dos benefícios econômicos por ela gerados.

Nesse contexto, pode-se enxergar uma possível solução para a angústia daqueles que, incansavelmente buscam encontrar um lugar para a business judgment rule no ordenamento jurídico brasileiro. Assim, surge uma terceira corrente que sustenta que, na realidade, a business judgment rule é compatível com o sistema de deveres e responsabilidades dos administradores previstos na Seção IV do Capítulo XII da LSA "como um todo, socorrendo-se, em alguns casos, de outras normas próprias do direito brasileiro". 53

Não é necessário encontrar uma norma ou um dispositivo específico que traduza a business judgment rule, basta, apenas, que haja uma correta interpretação dos requisitos para a sua aplicação no caso concreto. A busca por uma positivação literal da regra acaba surtindo um efeito quase que contrário ao seu real objetivo, tendo em vista que sua complexidade e mutabilidade não se coadunam com um dispositivo legal engessado, mas sim com uma interpretação do atuar do administrador que acompanhe e evolua em conjunto com o volátil desenvolvimento econômico.

Analisado o dever de diligência, cabe analisar, em sequência, o segundo dever fiduciário que tem fundamental importância quando da

\footnotetext{
${ }^{53}$ BRIGAGÃO, Pedro Henrique Castello. A Administração de Companhias e a Business Judgment Rule. São Paulo: Quartier Latin, 2017. p. 178.
} 
avaliação da atuação do conselho de administração nas tentativas de tomadas hostis. Trata-se do dever de lealdade. Sigamos à sua análise.

\subsection{Dever de Lealdade}

A positivação do dever de lealdade se deu pelo art. 155 da LSA, cujo teor transcrevemos abaixo:

"Art. 155. O administrador deve servir com lealdade à companhia e manter reserva sobre os seus negócios, sendo-lhe vedado:

I - usar, em benefício próprio ou de outrem, com ou sem prejuízo para a companhia, as oportunidades comerciais de que tenha conhecimento em razão do exercício de seu cargo;

II - omitir-se no exercício ou proteção de direitos da companhia ou, visando à obtenção de vantagens, para si ou para outrem, deixar de aproveitar oportunidades de negócio de interesse da companhia;

III - adquirir, para revender com lucro, bem ou direito que sabe necessário à companhia, ou que esta tencione adquirir.

$\S 1^{\circ}$ Cumpre, ademais, ao administrador de companhia aberta, guardar sigilo sobre qualquer informação que ainda não tenha sido divulgada para conhecimento do mercado, obtida em razão do cargo e capaz de influir de modo ponderável na cotação de valores mobiliários, sendo-lhe vedado valer-se da informação para obter, para si ou para outrem, vantagem mediante compra ou venda de valores mobiliários.

$\S 2^{\circ} \mathrm{O}$ administrador deve zelar para que a violação do disposto no $\S 1^{\circ}$ não possa ocorrer através de subordinados ou terceiros de sua confiança.

$\S 3^{\circ}$ A pessoa prejudicada em compra e venda de valores mobiliários, contratada com infração do disposto nos $\S \S 1^{\circ}$ e $2^{\circ}$, tem direito de haver do infrator indenização por perdas e danos, a menos que ao contratar já conhecesse a informação.

$\S 4^{0}$ É vedada a utilização de informação relevante ainda não divulgada, por qualquer pessoa que a ela tenha tido acesso, com a finalidade de auferir vantagem, para si ou para outrem, no mercado de valores mobiliários."

Conforme já exposto, o administrador está numa posição de vantagem. Em razão do cargo que ocupa, o administrador não só gere patrimônio alheio, como também tem exclusivo acesso a sensíveis informações e oportunidades de negócios que poderão afetar a companhia, seus acionistas e até mesmo o mercado como um todo. É justamente por estar em tal posição na relação de fidúcia que dele espera um comportamento ético, e, para tanto, a legislação impõe normas cogentes, sob o pano de fundo da boa-fé, cuja finalidade é obstar que o administrador 
obtenha vantagens indevidas em prejuízo daqueles que nele depositam a confiança de gerir seu patrimônio. A ideia, portanto, é de o administrador deve servir à companhia, e não dela se servir ${ }^{54}$. Em outras palavras, o objetivo do dever de lealdade é fazer com que tais informações e oportunidades sejam aproveitadas pelo administrador de modo a favorecer a companhia, e não meramente a si próprio.

Em virtude desta natural preocupação, surge o dever de lealdade que sugerirá determinadas condutas proibidas aos administradores que estão listadas no rol do art. 155 da LSA cuja natureza é meramente enunciativa.

Entre as diversas hipóteses nas quais os administradores devem se abster de praticar podem ser listadas: (i) não usurpar oportunidades da companhia; (ii) aproveitar em benefício próprio ou de terceiros as oportunidades surgidas durante a atividade social; (iii) não atuar em conflito de interesses; (iv) manter reserva sobre os negócios sociais; (v) não concorrer com a companhia; (vi) combater o uso de informações privilegiadas; (vii) manter sigilo sobre informações sensíveis; (viii) divulgar informações que o mercado já tenha conhecimento e que possam afetar a companhia; e (ix) divulgar amplamente todas as informações necessárias para a análise do desempenho da companhia (full disclosure).

Uma vez que cada dever fiduciário tem conteúdo e requisitos diversos, infere-se que a análise das condutas dos administradores será feita de maneira diferente a depender de qual dever fiduciário teria sido violado. Conforme mostramos acima, quando a conduta versar apenas sobre o dever de diligência, se preenchidos os requisitos necessários, o administradores gozará da proteção conferida pela business judgment rule, obstando, salvo comprovação de violação de qualquer destes requisitos, a análise do mérito de sua decisão e sua consequente responsabilização. Este princípio desenvolvido pela jurisprudência norte-americana não é, entretanto, nem

\footnotetext{
${ }^{54}$ CAMPOS, Luiz Antonio de Sampaio. In: LAMY FILHO, Alfredo; PEDREIRA, José Luiz Bulhões (Coord.). Direito das companhias. 2.ed. atual. refor. Rio de Janeiro: GEN, Forense, 2017. p. 821.
} 
naquele país, como no nosso, aplicável às situações de violações ao dever de lealdade.

Não obstante tal semelhança entre estes dois ordenamentos jurídicos, ocorre que, enquanto no Brasil, a impossibilidade de aplicação da business judgment rule apenas ensejará a análise do mérito do ato do administrador, nos EUA a não aplicação da business judgment rule implicará na análise do caso concreto à luz de outro standard comportamental, qual seja, a entire fairness doctrine.

Neste standard, diversamente do que ocorre na business judgment rule, o ônus da prova incumbirá ao administrador. Dessa forma caberá ao administrador comprovar o atendimento dos dois componentes da entire fairness.

O primeiro deles é o fair dealing que requererá a análise do momento (timing) da operação, ou seja, como ela se iniciou, como foi estruturada, como se deu a negociação, como ela foi exposta aos administradores e como foi obtida a aprovação do conselho de administração e dos acionistas.

O segundo componente é o fair price, que nada mais é do que a análise das questões econômicas e financeiras levantadas pela operação, e de outros elementos que influenciem no valor da companhia.

Dessa forma, em razão da necessidade de comprovação, por parte do administrador, do atendimento de seus requisitos, quais sejam, o fair dealing e o fair price, configura o entire fairness test como o mais rigoroso standard comportamental ${ }^{55}$.

Todavia, por mais rigoroso que seja, este standard, tal qual a business judgment rule, tendo seus requisitos preenchidos, obstará a imputação da responsabilidade ao administrador pelos danos causados por

\footnotetext{
${ }^{55}$ SCALZILLI, João Pedro. Mercado de Capitais, Ofertas Hostis e Técnicas de Defesa. São Paulo: Quartier Latin, 2015. p. 168.
} 
sua conduta. Assim, caberá ao administrador comprovar que o processo de negociação e o preço definido foram justos para os acionistas.

Conforme mostraremos adiante, tal dicotomia aparentemente simples, entre business judgment rule para decisões negociais desinteressadas, e entire fairness test para atos em conflito de interesses, encontra uma maior complexidade nas tomadas hostis. Pois, como veremos, nessa seara, a atuação do administrador ao mesmo tempo em que caracteriza uma decisão de cunho negocial, dá-se num cenário de um potencial conflito de interesses. Entretanto, antes de adentrarmos na seara da atuação dos administradores quando em face de uma oferta hostil, é preciso compreender o instituto das ofertas hostis e os efeitos dele decorrentes. 


\section{CAPÍTULO 4. AS OFERTAS HOSTIS PARA AQUISIÇÃO DO CONTROLE}

Adentrando no tema das ofertas hostis para aquisição do controle, cabe inicialmente esclarecer as formas pelas quais o poder controle de uma companhia pode ser adquirido. Nessa seara, a doutrina, há muito, separa as tais formas em uma dicotomia pela qual a aquisição do poder de controle pode ser classificada em originária ou derivada.

Considera-se originária a aquisição de controle que "resulta da formação, no patrimônio do acionista controlador, de bloco de controle que não existia - como universalidade - no patrimônio de outra pessoa",56.

Por sua vez, a:

"aquisição derivada do poder controle pressupõe sua transferência por pessoa que o detenha, e como o controle é poder de fato fundado no bloco de controle, sua transferência entre pessoas pressupõe a transmissão da propriedade do conjunto de ações, que é a fonte desse poder" ${ }^{\prime 57}$.

Fato é que, seja de maneira originária, seja de maneira derivada, diversas são as maneiras de adquirir o poder de controle de uma companhia, como, por exemplo, a escala em Bolsa de Valores, as convenções de voto, a cessão de controle externo, a alienação privada de controle, a subscrição de ações em aumento de capital, a conversão de outros valores mobiliários, como debêntures ou bônus de subscrição, em ações com direito a voto, a aquisição de direito de voto por ações preferenciais em caso de não pagamento dos dividendos, a concessão de usufruto de ações, dentre muitos outros. No entanto, o cerne do presente estudo são as tomadas de controle hostis e é por tal motivo que não trataremos das demais formas de aquisição do poder de controle.

\footnotetext{
${ }^{56}$ LAMY FILHO, Alfredo; PEDREIRA, José Luiz Bulhões (Coord.). Direito das companhias. 2.ed. atual. refor. Rio de Janeiro: GEN, Forense, 2017, p. 601

${ }^{57}$ LAMY FILHO, Alfredo; PEDREIRA, José Luiz Bulhões (Coord.). Ibid, p. 602
} 


\subsection{Conceito de Oferta Hostil e sua Natureza Jurídica}

Conforme apresentado até aqui, percebemos que o mercado de capitais brasileiro tem apresentado uma onda de dispersão acionária, gerando o surgimento de diversas companhias sob controle minoritário e até mesmo a possibilidade de (e quiçá a) existência de companhias com controle gerencial, ainda que, reconheçamos, no mínimo em fase embrionária.

Dentro deste cenário de pulverização, somada a atual baixa da economia nacional, observamos que muitas companhias de capital disperso têm operado abaixo do que podem, seja em virtude de decisões equivocadas, seja por terem sido afetadas pela crise econômica ou até mesmo pela implantação de projetos de longo prazo. É justamente nessa conjuntura que as ofertas hostis se tornam importantes instrumentos para a transferência do controle acionário.

Como já informamos, o presente estudo não adota ou defende qualquer tipo de ideologia pré-concebida. Desse modo, tal forma de transferência do controle acionário não poderá ser de maneira alguma definida per si como positiva ou negativa. Não cabe sobre este instituto qualquer tipo de juízo valorativo a priori. A análise, portanto, deverá ser casuística, buscando-se, por exemplo, aferir se se está diante um mero especulador que visa obter vantagens de uma companhia próspera que opera em baixa momentânea, ou se de fato está-se diante de um investidor que reconheceu o potencial de uma companhia mal administrada.

Todavia, antes de adentrarmos nos aspectos e participantes desta análise, incluindo dentre eles, o conselho de administração, algumas premissas devem ser previamente fixadas.

Em primeiro lugar, é preciso esclarecer que as tomadas hostis pressupõem dois requisitos de natureza cumulativa: (i) ausência de controle definido por titularidade de direitos de voto (logo, $50 \%$ mais uma ação do 
capital votante da companhia-alvo devem estar necessariamente no free float); e (ii) negociação das ações companhia-alvo em Bolsa de Valores.

Da análise dos requisitos acima, depreende-se, conforme adiantado, que apenas poderão ser objeto de tomadas hostis as companhias abertas ${ }^{58}$ que estejam sob controle minoritário ou gerencial. Consequentemente, a aquisição por meio de oferta hostil se caracteriza por ser uma forma de aquisição de controle originária.

Sendo preenchidos os dois requisitos acima, poderemos falar em tomada hostil de controle quando alguém, sem negociar ou notificar previamente a administração de uma companhia (ou até mesmo seu controlador minoritário), realiza uma oferta pública, direcionada indistintamente aos acionistas da companhia-alvo, a fim de adquirir certo montante de ações que lhe possibilitará exercer o poder de controle sobre aquela sociedade. Nas sempre sábias palavras do já saudoso mestre Alfredo Lamy Filho:

“[...] oferta pública para aquisição de controle é negócio unilateral mediante o qual o ofertante faz oferta pública de ações (e não do bloco de controle) em número suficiente para formar o bloco de controle; não há, nessa hipótese, alienação de controle, e sim aquisição originária do controle." ${ }^{, 59}$

Desse modo, pode-se concluir que a oferta hostil se caracteriza por ser uma forma de aquisição do poder de controle: (i) originária; (ii) voluntária, pois exige a manifestação de vontade do ofertante; e (iii) decorrente de operação isolada, uma vez que tal forma, diferentemente de

\footnotetext{
${ }^{58}$ Consequentemente, nunca estaremos diante de uma tomada hostil cuja companhia-alvo não possua conselho de administração, visto que o $\S 2^{\circ}$ do art. 138 da LSA determina que o conselho de administração deve obrigatoriamente existir nas companhias de capital aberto:

"Art. 138. A administração da companhia competirá, conforme dispuser o estatuto, ao conselho de administração e à diretoria, ou somente à diretoria.

$\S 1^{\circ} \mathrm{O}$ conselho de administração é órgão de deliberação colegiada, sendo a representação da companhia privativa dos diretores.

$\S 2^{\circ}$ As companhias abertas e as de capital autorizado terão, obrigatoriamente, conselho de administração."

${ }^{59}$ LAMY FILHO, Alfredo; BULHÕES PEDREIRA, José Luiz. A Lei das S.A. v. 2, $2^{\mathrm{a}}$ ed. Rio de Janeiro: Renovar, 1996. p.676
} 
outras maneiras de se adquirir o controle, como, por exemplo, a escalada em Bolsa, dá-se em uma única operação ${ }^{60}$.

Outra característica das ofertas hostis é, por óbvio, sua "hostilidade". Entretanto, tal hostilidade não tem qualquer de conotação negativa, seja de ilegalidade, imoralidade ou até no sentido de ser prejudicial à companhia ou aos seus acionistas. Como já informamos, não cabe sobre este instituto qualquer tipo de análise valorativa em abstrato. $\mathrm{Na}$ verdade, a hostilidade dessa forma de aquisição do poder de controle não é relacionada à companhia-alvo. Conforme veremos, a tomada hostil não será necessariamente prejudicial aos acionistas, em sua generalidade, à companhia ou ao mercado. A oferta é "hostil", portanto, em relação à administração daquela companhia, uma vez que (i) a ausência do consentimento dos seus membros per si em nada afetará por si só sucesso ou o insucesso da operação e (ii) que é provável que a primeira medida a ser adotada após a tomada do controle seja a alteração na composição dos membros da administração da companhia-alvo ${ }^{61,62}$.

Analisados o conceito, requisitos e características das ofertas hostis, cabe, antes de discorremos acerca da atuação dos membros do conselho de administração nas ofertas hostis, apresentar (i) o modo pelo qual esta forma de aquisição do poder de controle acionário está inserida no nosso ordenamento jurídico, (ii) suas vantagens e desvantagens, bem como (iii) o potencial conflito de interesses que dela advém.

\footnotetext{
${ }^{60}$ NASCIMENTO, João Pedro Barroso do. Medidas Defensivas à Tomada de Controle de Companhias. São Paulo: Quartier Latin, 2011. p. 75

61 "Nesse movimento, o ofertante não consulta nem avisa previamente aos administradores ou aos controladores da companhia, pois há a real possibilidade do efetivo sucesso da operação, mesmo contra a vontade desses. Daí a denominação "hostil", que, embora dê uma conotação pejorativa ao mecanismo, não passa de um jargão de mercado, visto que a oferta pode muito bem ser positiva para os acionistas, para a companhia assediada e para o mercado de uma maneira geral". SCALZILLI, João Pedro. Mercado de Capitais, Ofertas Hostis e Técnicas de Defesa. São Paulo: Quartier Latin, 2015. p. 122

${ }^{62}$ A oferta tecnicamente também pode ser hostil ao controlador minoritário, pois obtendo êxito, retirará deste comando sobre a administração da companhia.
} 
O instituto da oferta hostil se encontra positivado no ordenamento jurídico brasileiro. Na verdade, esse meio de aquisição do poder de controle nada mais é que uma espécie do gênero Oferta Pública de Ações ${ }^{63}$, mais especificamente a Oferta Pública para Aquisição Controle, cujo fundamento legal reside no art. 257 da LSA:

“Art. 257. A oferta pública para aquisição de controle de companhia aberta somente poderá ser feita com a participação de instituição financeira que garanta o cumprimento das obrigações assumidas pelo ofertante.

$\S 1^{\circ}$ Se a oferta contiver permuta, total ou parcial, dos valores mobiliários, somente poderá ser efetuada após prévio registro na Comissão de Valores Mobiliários.

$\S 2^{\circ}$ A oferta deverá ter por objeto ações com direito a voto em número suficiente para assegurar o controle da companhia e será irrevogável.

$\S 3^{\circ} \mathrm{Se}$ o ofertante já for titular de ações votantes do capital da companhia, a oferta poderá ter por objeto o número de ações necessário para completar o controle, mas o ofertante deverá fazer prova, perante a Comissão de Valores Mobiliários, das ações de sua propriedade.

$\S 4^{\circ}$ A Comissão de Valores Mobiliários poderá expedir normas sobre oferta pública de aquisição de controle."

À luz dos elementos observados nos termos do dispositivo legal transcrito acima, conclui-se que a oferta pública para aquisição controle tem natureza jurídica de "proposta irrevogável, dirigida a todos os acionistas da companhia que forem detentores de ações com direito de voto, por meio da qual se propõe a celebração de um contrato de compra e venda ou de permuta de um bloco de ações" $"$.

Ademais, é importante destacar que toda oferta hostil será uma oferta pública para aquisição controle, no entanto, a recíproca pode ser falaciosa. Assim, é possível que a oferta pública para aquisição controle se dê amigavelmente, tendo seus termos negociados diretamente com a administração da companhia.

Conceituado o próprio instituto da oferta pública para aquisição controle e sua natureza jurídica, faz-se necessário avaliar quais os motivos

\footnotetext{
${ }^{63}$ Além da Oferta Pública para Aquisição de Controle, hostil ou não, existem outras cinco espécies de OPA: (i) OPA para Fechamento de Capital; (ii) OPA por Aumento de Participação; (iii) OPA por Alienação de Controle; (iv) OPA Concorrente; e (v) OPA voluntária.

${ }^{64}$ SCALZILLI, João Pedro. Mercado de Capitais, Ofertas Hostis e Técnicas de Defesa. São Paulo: Quartier Latin, 2015. p. 138.
} 
que levariam alguém a realizá-la e as vantagens e desvantagens que dela podem decorrer.

\subsection{Vantagens e Desvantagens das Tomadas Hostis}

Conforme já mencionamos, as ofertas hostis são voltadas para companhias abertas sob controle minoritário ou gerencial que, em regra, estão enfrentando aparentes problemas, sejam estes de natureza econômica, financeira e/ou operacional, e, em virtude de tais dificuldades, encontram-se desvalorizadas perante o mercado ${ }^{65}$.

Observando essa conjuntura, surge um indivíduo que pode perceber que (i) ou a companhia-alvo está sendo mal administrada e possui um potencial maior do que vem apresentando, e, a partir desta constatação, tomará esforços para adquirir tal companhia por um preço abaixo do seu real valor, porém acima do valor de mercado $^{66}$, (ii) ou a companhia-alvo possui ativos valiosos e é um alvo fácil, visto que seus acionistas estarão interessados em liquidar suas respectivas participações societárias, levandoo a buscar adquirir o controle daquela companhia para posteriormente obter vantagens pessoais às custas da companhia.

Como se sabe, em regra, as aquisições de participações societárias se dão privadamente, ou seja, através de uma negociação direta entre adquirente e acionista alienante. Ocorre, porém, que, conforme apresentado acima, as companhias que podem ser objeto de tomadas hostis devem apresentar necessariamente controle minoritário ou gerencial, o que faz aferir que tais companhias terão um alto free float. Tal fato significa que os custos de transação incorridos numa negociação serão altíssimos, pois o adquirente deverá negociar com cada um dos milhares acionistas, ainda

\footnotetext{
${ }^{65}$ Não serão apenas as companhias que estão operando em baixa que serão alvo de ofertas hostis. É comum a utilização desse meio para que se adquira companhias em alta apenas para ter ganhos de sinergia, formar de um grupo econômico, ou até mesmo para dispor de seus ativos.

${ }^{66}$ Obviamente, nenhum acionista de uma companhia aberta aceitaria alienar suas ações por um valor abaixo do que ele pode obter na Bolsa de Valores.
} 
mais quando houver um controlador minoritário que não esteja disposto a abrir mão de suas ações.

A OPA para aquisição de controle surge, portanto, como mitigadora de parte dos custos de transação, pois o adquirente, ao realizar a oferta pública, não será mais obrigado a negociar individualmente com cada acionista, uma vez que poderá, por meio desta OPA, realizar proposta à generalidade dos acionistas. Tal característica das ofertas públicas será benéfica aos acionistas que poderão avaliar melhor a oferta e receber tratamento equitativo ${ }^{67}$.

Não obstante o disposto acima, fato é que a oferta pública para aquisição do controle, seja ela hostil ou amigável, apresenta algumas desvantagens em relação às outras formas de aquisição de controle.

A primeira destas desvantagens se refere justamente ao custo financeiro da transação. Em relação à alienação privada, que permite uma negociação privada entre ofertante e adquirente, e à escalada em Bolsa de valores, percebe-se que uma das problemáticas das ofertas públicas para aquisição do controle reside na obrigatoriedade de pagamento do preço em parcela única, diversamente daquelas duas outras formas de aquisição do poder de controle nas quais se permite que a aquisição, e, consequentemente, o pagamento do preço, se deem gradativamente, permitindo ao adquirente, portanto, uma maior possibilidade acerca da conveniência e oportunidade da aquisição ${ }^{68,69,70}$.

Novamente em relação à alienação privada, pode-se extrair outra desvantagem das ofertas públicas para aquisição do controle. Trata-se de

\footnotetext{
${ }^{67}$ Entretanto, conforme demonstraremos, o problema da ação coletiva tem uma alta probabilidade de acarretar em uma assimetria informacional e forte pressão sobre os acionistas.

${ }^{68}$ SCALZILLI, João Pedro. Mercado de Capitais, Ofertas Hostis e Técnicas de Defesa. São Paulo: Quartier Latin, 2015. p. 141.

69 "Entretanto, a possibilidade de uma Exchange tender offer pode contornar esse empecilho" SCALZILLI, João Pedro. Mercado de Capitais, Ofertas Hostis e Técnicas de Defesa. São Paulo: Quartier Latin, 2015. p. 141

${ }^{70}$ Uma das maneiras de se solucionar tal problema é através da estruturação de uma Leveraged Buyout (LBO) que nada mais é que uma operação de aquisição de controle na qual "uma parcela significativa dos recursos utilizados para o pagamento das ações é financiado por dívida assumida pelo ofertante". NASCIMENTO, João Pedro Barroso do. Medidas Defensivas à Tomada de Controle de Companhias. São Paulo: Quartier Latin, 2011. p. 101
} 
desvantagem de caráter informacional. Como se sabe uma aquisição privada é geralmente precedida de uma due diligence na qual o adquirente obtém acesso às principais informações da companhia e dos acionistas alienantes, que muito provavelmente não foram divulgadas ao público ${ }^{71}$. Dessa forma, percebe-se que na alienação privada o adquirente terá maiores informações e, portanto, poderá fazer uma análise mais aprofundada da adequação do preço a ser pago.

Por fim, também em relação à alienação privada, na geralmente se iniciam as negociações através da celebração de um non disclosure agreement, a fim de se evitar justamente que a notícia se espalhe e acarrete em um leilão que fará variar a cotação das ações, a oferta pública para aquisição do controle, em razão do seu viés público, acaba por despertar concorrentes.

Considerando as problemáticas supramencionadas, poder-se-ia questionar por que alguém optaria por realizar uma oferta pública para aquisição do controle. Por óbvio, a razão é a mesma pela qual se optaria por qualquer outra forma de aquisição do poder de controle: o instituto da oferta pública para aquisição do controle possui vantagens que, a depender do caso concreto, superam suas desvantagens. Passaremos, com isso, à análise das vantagens deste instituto.

Inicialmente, afere-se que a oferta pública para aquisição do controle, como regra geral, tem um custo de aquisição inferior já que possibilita ao ofertante:

\footnotetext{
"adquirir apenas o número estritamente necessário de ações que lhe garanta o poder de controle, ao passo que, em uma alienação privada, por vezes, o adquirente é obrigado a comprar um bloco muito maior do que o desejado, tendo em vista que o atual controlador dificilmente estaria disposto a ficar 'preso' em uma posição minoritária"72.

Tal fato se dá pois, na OPA para aquisição de controle, o ofertante, não atingindo seu objetivo, não precisará adquirir nenhuma ação da

${ }^{71}$ SCALZILLI, João Pedro. Mercado de Capitais, Ofertas Hostis e Técnicas de Defesa. São Paulo: Quartier Latin, 2015. p. 141

${ }^{72}$ SCALZILLI, João Pedro. Ibid., p. 140
} 
companhia-alvo, diversamente do que ocorre, por exemplo, na escalada em Bolsa de valores e em certas alienações privadas.

Outro aspecto positivo da OPA para aquisição de controle a ser destacado é sua previsibilidade temporal. Conforme a prática demonstra, essa espécie de oferta pública costuma levar de fato o tempo estipulado na proposta.

As vantagens das OPAs para aquisição do controle são voltadas também para os acionistas da companhia-alvo. Como se sabe, uma das caraterísticas das ofertas públicas é a generalidade, ou seja, elas se dirigem indistintamente a todos os acionistas da companhia-alvo (no caso da OPA para aquisição de controle, esta se volta para todos os acionistas titulares de ações com direitos de voto). Desse modo, os acionistas da companhia gozarão da possibilidade de partilhar o prêmio de controle, bem como de receber amplas informações a fim de tomar uma decisão mais consciente sobre alienar ou não suas participações societárias.

As OPAs para aquisição de controle podem beneficiar ainda o próprio mercado e companhia-alvo por meio de ganhos de sinergia, formação de monopólios, aprimoramento dos track record dos administradores da ofertante, venda de ativos da companhia-alvo (pilhagem), dentre outros.

Como mencionamos acima, as ofertas hostis costumam estar voltadas para companhias em baixa no mercado. Assim, quando o mercado considerar que uma companhia esteja atuando adequadamente, dificilmente ocorrerá uma oferta hostil. A razão para tal conclusão é simples: o ofertante não terá expectativa de receber altos retornos financeiros em decorrência daquela aquisição. Consequentemente, costumam ser objeto de ofertas hostis as companhias cuja cotação das ações de sua emissão esteja em baixa no mercado, isto é, companhias reputadas como subvalorizadas, seja em virtude de opções de negócios equivocadas, seja por dificuldades 
financeiras, econômicas, e/ou operacionais, de caráter transitório ou não, dentre outras ${ }^{73}$.

Conforme trataremos adiante, uma das inevitáveis consequências do sucesso de uma tomada hostil de controle é a substituição dos membros do conselho de administração. Assim, as ofertas hostis servem como forte estímulo à administração das companhias. A fim de manter seus respectivos cargos, os administradores deverão exercer adequadamente suas funções no intuito de maximizar a riqueza da companhia e, consequentemente, daqueles que nele confiaram a gerência de seu patrimônio, os acionistas, visto que, do contrário, haverá sempre a possibilidade de uma oferta hostil. Com efeito, explica-se o que aludimos acima, isto é, de que as ofertas hostis constituem um importante mecanismo de alinhamento de interesses, implicando na redução dos custos de agência, uma vez que estimulará os agentes (administradores) a atuar com vistas no interesse do principal (acionista). Contudo, apesar de abordarmos tal tema de maneira mais aprofundada adiante, cumpre adiantar que o interesse dos acionistas não deve guiar única e exclusivamente a atuação dos administradores, uma vez que estes têm deveres para com a companhia ${ }^{74}$.

\footnotetext{
73 "As ofertas hostis são comuns quando as ações de emissão da companhia objeto estão subavaliadas e não atingem seu potencial de cotação devido à administração inefíciente." EIZIRIK, Nelson. A Lei das S/A Comentada. v. III. São Paulo: Quartier Latin, 2011. p. 459.

${ }^{74}$ Como se lê dos termos do art. 154 da LSA, o "administrador deve exercer as atribuições que a lei e o estatuto the conferem para lograr os fins e no interesse da companhia, satisfeitas as exigências do bem público e da função social da empresa".

"Art. 154. O administrador deve exercer as atribuições que a lei e o estatuto lhe conferem para lograr os fins e no interesse da companhia, satisfeitas as exigências do bem público e da função social da empresa.

$\S 1^{\circ} \mathrm{O}$ administrador eleito por grupo ou classe de acionistas tem, para com a companhia, os mesmos deveres que os demais, não podendo, ainda que para defesa do interesse dos que o elegeram, faltar a esses deveres.

$\S 2{ }^{\circ}$ É vedado ao administrador:

a) praticar ato de liberalidade à custa da companhia;

b) sem prévia autorização da assembléia-geral ou do conselho de administração, tomar por empréstimo recursos ou bens da companhia, ou usar, em proveito próprio, de sociedade em que tenha interesse, ou de terceiros, os seus bens, serviços ou crédito;

c) receber de terceiros, sem autorização estatutária ou da assembléia-geral, qualquer modalidade de vantagem pessoal, direta ou indireta, em razão do exercício de seu cargo.

$\S 3^{\circ}$ As importâncias recebidas com infração ao disposto na alínea $\mathrm{c}$ do $\S 2^{\circ}$ pertencerão à companhia.
} 
Cumpre ainda mencionar que as tomadas hostis podem ser benéficas ao próprio mercado como um todo por serem excelentes mecanismos de "seleção natural" no meio empresarial. Em outras palavras, somente os administradores eficientes manterão seus cargos. Aqueles que, por outro lado, não obtiverem bons resultados serão dispensados de suas funções e dificilmente voltarão ao mercado. Assim, ao fim, o mercado se encontrará com companhias bem administradas, estimulando, por conseguinte, os investimentos e movimentando a economia.

Não obstante o exposto acima, fato é que, por mais que o mercado de capitais preze pelo full and fair disclosure, este não é, em si, $100 \%$ eficiente. Tal fato decorre da permanente existência de assimetrias informacionais que impossibilitarão uma perfeita avaliação do valor de mercado de todas as companhias. Por consequência, ainda que a possibilidade de ocorrência de uma oferta hostil, ao reduzir os custos de agência, e que sua concretização, por permitir ganhos em razão das mudanças dos membros do conselho de administração, possa ser benéfica à companhia-alvo e aos seus acionistas, como um todo, tal forma de aquisição de poder de controle também pode se revelar extremamente prejudicial a todos os participantes do mercado.

Já expusemos aqui que as companhias que não estejam bem reputadas no mercado serão as que, em regra, figurarão como objeto de ofertas hostis. Contudo, também já vimos que o mercado não é integralmente eficiente. Consequentemente, muitas vezes uma determinada companhia está passando por dificuldades meramente momentâneas, seja em virtude de projetos de longo prazo, por questões de mercado, ou até por ter estar investindo em uma tecnologia ainda não divulgada. Tais companhias acabarão sendo subavaliadas pelo mercado, independentemente dos benefícios que, pelas razões acima (dentre outras), serão gerados no

$\S 4^{\circ} \mathrm{O}$ conselho de administração ou a diretoria podem autorizar a prática de atos gratuitos razoáveis em benefício dos empregados ou da comunidade de que participe a empresa, tendo em vista suas responsabilidades sociais. 
longo prazo às próprias companhias, aos seus acionistas e aos seus demais stakeholders.

Assim, tais companhias, em razão da existência das ofertas hostis, poderão ser alvo de especuladores que em nada estarão preocupados com a sua continuidade e preservação, buscando apenas obter lucros no curto prazo, prejudicando a companhia em si, seus stakeholders e até o mercado como um todo pela extinção de companhias prósperas.

Dessa forma, considerando que as ofertas hostis apresentam significativos aspectos positivos e negativos, impõe-se às elas a necessidade de uma análise casuística. Tal fato decorre de dois grandes motivos.

Em primeiro lugar, visto não ser o mercado totalmente eficiente, haverá sempre a possibilidade de se tratar tanto de uma companhia mal administrada quanto de uma companhia com dificuldades de caráter transitório, em razão de projetos de longo prazo ou que simplesmente não foram divulgados ainda pela administração. Assim, não se saberá a priori jamais qual das duas hipóteses ocorre no caso concreto.

Além disso, é inegável o fato de que, na conjuntura de uma oferta hostil, haverá sempre um potencial conflito de interesses por parte dos administradores que, por mais que atuem no intuito de preservar a companhia, por meio de uma decisão meramente negocial, estarão potencialmente interessados naquela operação, uma vez que seus empregos estão em jogo, dificultando-se, assim, uma análise imparcial. Por outro lado, são justamente os membros da administração aqueles que mais conhecem a companhia, fazendo com que sua opinião tenha caráter extremamente relevante. ${ }^{75}$

\footnotetext{
75 "Nesse novo cenário, muito se discute como se deve portar o Conselho quando surge uma oportunidade de vender o negócio. Não é uma situação fácil, já que a concretização de uma transferência de controle ou fusão com uma companhia de maior porte provavelmente implicará na perda do emprego para os membros do Conselho. Existe, portanto, uma clara situação de conflito de interesses e, dessa forma, muitos sustentam que a opinião do Conselho sobre o negócio fica prejudicada pela falta de imparcialidade. Por outro lado, poucos conhecem a companhia tão bem quanto o Conselho de Administração. É o Conselho o responsável pela definição do planejamento estratégico da companhia, pela visão de longo prazo e estabelecimento das metas de crescimento para a diretoria. Difícil imaginar, portanto, quem estaria melhor posicionado para avaliar se o
} 
Dessa forma, em razão (i) da impossibilidade de verificação abstrata de benefício ou prejuízo que possa advir da oferta hostil, (ii) do mencionado potencial conflito de interesses, e (iii) informações que os administradores detém acerca da companhia decorrentes da posição que ocupam, percebe-se que a possibilidade e a extensão da atuação dos administradores no cenário de uma tomada hostil requer uma análise aprofundada.

Entretanto, antes de adentrarmos diretamente nesta seara, faz-se necessário analisar como se dá o procedimento das ofertas públicas para aquisição de controle, de forma a facilitar a visualização da conjuntura na qual incidirá a possibilidade de atuação dos administradores.

\subsection{Aspectos Procedimentais da OPA para Aquisição de Controle}

Como já explicitado, a oferta hostil nada mais é que uma modalidade de OPA, e, por isso, tem natureza jurídica de proposta $^{76}$. Consequentemente, tal oferta se realizará por meio de um instrumento pelo qual o ofertante, a fim de obter o poder de controle daquela sociedade, irá expor ao mercado e aos acionistas da companhia-alvo a sua vontade de adquirir as ações desses.

A elaboração e a publicação desse instrumento se darão apenas após um período entre o momento no qual o ofertante estruturará a operação (em geral, cercado de diversos tipos de profissionais, como, por exemplo, consultores especializados, bancos de investimentos e advogados), e realizará negociações com a instituição financeira responsável por assegurar a liquidez da operação, até a realização de um registro prévio perante a

preço oferecido em uma oferta para a aquisição de controle é atrativo ou se uma proposta de fusão deverá efetivamente levar a uma valorização da participação detida pelos acionistas. Da mesma forma, em uma operação de fusão, ninguém melhor que o Conselho para avaliar uma relação de troca proposta pela outra parte." SILVA, Carlos Alexandre Lobo e. A evolução da aquisição de controle de companhias abertas no Brasil. In: SILVA, Alexandre Couto [coordenador]. Direito societário. São Paulo: Saraiva, 2013. p. 249.

76 "Constitui a oferta, portanto, um ato jurídico autônomo, não se confundindo com o contrato cuja formação contribui. É um ato negocial, pois representa uma vontade definitivamente separada de seu autor e que se torna objetiva". CARVALHOSA, Modesto. Comentários à Lei de Sociedades Anônimas. v. 4, t. II, $2^{\mathrm{a}}$ ed. rev. São Paulo: Saraiva, 2003. p. 210. 
CVM, caso haja tal necessidade. Durante esta fase até a publicação da oferta, exige o art. 260 da $\operatorname{LSA}^{77}$, que o ofertante, a instituição financeira e a CVM mantenham sigilo acerca dessa operação ${ }^{78}$.

Este instrumento da oferta pública de aquisição de ações tem seus elementos obrigatórios elencados no art. 258 da LSA que assim dispõe:

"Art. 258. O instrumento de oferta de compra, firmado pelo ofertante e pela instituição financeira que garante o pagamento, será publicado na imprensa e deverá indicar:

I - o número mínimo de ações que o ofertante se propõe a adquirir e, se for o caso, o número máximo;

II - o preço e as condições de pagamento;

III - a subordinação da oferta ao número mínimo de aceitantes e a forma de rateio entre os aceitantes, se o número deles ultrapassar o máximo fixado;

IV - o procedimento que deverá ser adotado pelos acionistas aceitantes para manifestar a sua aceitação e efetivar a transferência das ações;

V - o prazo de validade da oferta, que não poderá ser inferior a 20 (vinte) dias;

VI - informações sobre o ofertante.

Parágrafo único. A oferta será comunicada à Comissão de Valores Mobiliários dentro de 24 (vinte e quatro) horas da primeira publicação."

Com efeito, deverão constar no instrumento: (i) o objeto da oferta (as

ações ordinárias e preferenciais com direito a voto da companhia-alvo) ${ }^{79}$;

77 Art. 260. Até a publicação da oferta, o ofertante, a instituição financeira intermediária e a Comissão de Valores Mobiliários devem manter sigilo sobre a oferta projetada, respondendo o infrator pelos danos que causar.

${ }^{78}$ Durante essa chamada "fase secreta", não poderá ser divulgada qualquer informação acerca da OPA. A ratio do dispositivo é evitar que ocorram oscilações atípicas (quando não artificiais) da cotação das ações da companhia-alvo. Como se sabe, uma oferta pública tende a elevar a cotação das ações que serão objeto da proposta a ser formulada. Dessa forma, o mero anúncio de uma oferta pública poderia servir de instrumento para formação de preços artificiais. Para tanto, o art. 260 exige o dever de sigilo, de forma a possibilitar que o mercado mantenha a sua eficácia. Em que pese nossa concordância com tal preocupação, questionamo-nos se, de fato, é necessário que a oferta esteja integralmente definida para que possa ser divulgada. Ou seja, é de fato preciso que um eventual financiamento necessário já tenha sido obtido, que já se tenha ciência de qual será o preço ofertado, de quais condições serão impostas? Nesse aspecto, acreditamos que a oferta não precise estar inteiramente definida para que possa ser divulgada ao mercado. Entendemos que essa questão deva ser tratada com base no principio do fair and full disclosure, isto é, quando da divulgação, caberá ao ofertante informar acerca da completude da oferta que será formulada e da relevância que os aspectos ainda não definidos podem ter em relação à decisão dos acionistas de forma a evitar oscilações atípicas nas cotações dos valores mobiliários que serão objeto da oferta, e possibilitando a manutenção da eficácia do mercado e, consequentemente, do estímulo ao investimento.

${ }^{79}$ Como se sabe, o poder de controle pressupõe, por parte daquele que o detém, a possibilidade do exercício do direito de voto de forma a fazer prevalecer, de forma preponderante e permanente, a sua vontade. Por isso, o objeto da oferta hostil serão as ações que tenham direito a voto. Entretanto, as ofertas públicas para aquisição de ações podem ser amigáveis, e, nesses casos, podem ser formuladas para adquirir ações com e/ou sem direito de voto. 
(ii) o $\operatorname{preço}^{80}$ a ser pago pelas ações, que poderá se dar em dinheiro ${ }^{81}$, valores mobiliários, ou até mesmo uma combinação dos dois; (iii) as condições do pagamento (a subordinação da oferta ao número mínimo de aceitantes e a forma de rateio entre os aceitantes, se o número deles ultrapassar o máximo fixado) ${ }^{82}$; (iv) a forma pela qual os acionistas da companhia-alvo deverão demonstrar a aceitação da proposta ${ }^{83} ;(\mathrm{v})$ o prazo de validade da proposta, sendo o mínimo de 20 (vinte) dias; e (vi) informações sobre o ofertante ${ }^{84}$.

${ }^{80}$ É de suma importância compreender que o preço a ser pago será sempre acima do valor de cotação das ações, uma vez que, do contrário, os acionistas não aceitariam a oferta, pois bastaria que vendesse suas ações em bolsa.

${ }^{81} \mathrm{Em}$ geral, essa forma de pagamento é mais atrativa aos acionistas, pois os facilita quando da apreciação do ganho em questão já que basta observar a diferença entre o valor da proposta e da cotação, sendo muito menos complexo que a análise do laudo de avaliação que analisa a relação de troca no caso de permuta.

${ }^{82}$ Conforme abordado, a oferta hostil tem como uma das suas vantagens, quando em relação a outras formas de aquisição, a possibilidade de o ofertante, em caso de insucesso, não adquirir nenhuma das ações da companhia-alvo. Logo, é natural que o autor da proposta imponha a condição de que o contrato só terá eficácia caso o mínimo de ações necessárias à obtenção do poder de controle seja adquirido. Trata-se de condição suspensiva. É dizer, o contrato está formado, porém seus efeitos se sujeitam à verificação da condição estabelecida.

${ }^{83} \mathrm{~A}$ aceitação se dá através de ordens de venda junto às instituições financeiras ou no Mercado de Valores Mobiliários conforme dispuser o instrumento. Trata-se de aceitação incondicional (não se admitindo qualquer tipo de reserva) e irretratável:

Art. 261. A aceitação da oferta deverá ser feita nas instituições financeiras ou do mercado de valores mobiliários indicadas no instrumento de oferta e os aceitantes deverão firmar ordens irrevogáveis de venda ou permuta, nas condições ofertadas, ressalvado o disposto no $\S 1^{\circ}$ do artigo 262.

$\S 1^{\circ}$ É facultado ao ofertante melhorar, uma vez, as condições de preço ou forma de pagamento, desde que em porcentagem igual ou superior a 5\% (cinco por cento) e até 10 (dez) dias antes do término do prazo da oferta; as novas condições se estenderão aos acionistas que já tiverem aceito a oferta.

$\S 2^{\circ}$ Findo o prazo da oferta, a instituição financeira intermediária comunicará o resultado à Comissão de Valores Mobiliários e, mediante publicação pela imprensa, aos aceitantes.

$\S 3^{\circ}$ Se o número de aceitantes ultrapassar o máximo, será obrigatório o rateio, na forma prevista no instrumento da oferta.

A aceitação conclui a formação do contrato, gerando a obrigação do acionista da companhia-alvo de entregar suas ações ao ofertante e deste de pagar o preço estabelecido na proposta. Em caso de descumprimento de tal obrigação, sujeitar-se-á o ofertante às disposições do Código Civil relativas à responsabilidade contratual. Em caso de inadimplemento do oblato, poderá o ofertante requisitar ao juiz o suprimento da vontade do acionista da companhia-alvo, por força do art. 464 do Código Civil.

84 "O instrumento deverá declinar de forma pormenorizada as informações sobre o ofertante, a fim de propiciar aos destinatários os dados completos acerca daquele que lhes propõe a celebração do contrato. Mas não é só isso: os acionistas devem possuir plenas condições de avaliar a qualidade da proposta que lhes é feita. O Securities and Exchange Act (dos EUA) inclui nas informações a serem reveladas pelo ofertante as suas reais intenções com relação à companhia-alvo. Assim, se a motivação para a tomada de controle é uma futura fusão ou incorporação, a venda de um ativo importante, a liquidação, ou mesmo outra mudança drástica nos negócios ou na estrutura societária da companhia-alvo, essas devem ser comunicadas. No Brasil, como salienta Carvalhosa, também devem ser revelados os propósitos do ofertante no que concerne ao futuro da empresa-alvo da 
Faz-se necessário ainda esclarecer que, como regra geral, não se permite ao ofertante a retratação durante o prazo no qual os acionistas decidirão se aceitam ou não a oferta, bem como não se reputa válida qualquer cláusula que disponha em contrário, no sentido de garantir ao ofertante a possibilidade de se retratar.

A regra acima, contudo, pode ser excepcionada. É o que prevê a alínea "a" do art. $5^{\circ}, \S 2^{\circ}$, III da Instrução CVM n. ${ }^{\circ} 361 / 02^{85}$, que adotou a

oferta. Nesse sentido, deve haver a comunicação sobre se haverá ou não modificações na estrutura jurídica daquela (transformação, incorporação, fusão ou cisão) ou se ela está fadada a fazer parte de um grupo de sociedades, além de informações de cunho eminentemente negocial, como a manutenção das plantas industriais, as alterações referentes à linha de produção de bens ou de serviços daquela (modificação, expansão, diversificação) e outros fatores. Essas informações são bastante importantes, sobretudo para os acionistas, que podem, inclusive, decidir continuar como sócios se acreditarem que o novo controlador tomará o controle da companhia de qualquer forma e incrementará o seu desempenho, valorizando, consequentemente, os seus papéis. Segundo o disposto no art. $4^{\circ}$, II, da Instrução 361 da CVM, a OPA será realizada de modo a assegurar aos destinatários elementos necessários à tomada de uma decisão refletida e independente. Dessa forma, a omissão ou a falsa informação induz o oblato em erro e ocasiona responsabilidade do policitante. Deve-se destacar que não é somente aos acionistas para os quais se dirige essa regra de full and fair disclosure, pois o mercado e a companhia-alvo também devem possuir plena capacidade para julgar a qualidade da proposta. Por isso, são informações essenciais: (i) o nome da ofertante, (ii) o seu objeto social, (iii) o capital social, (iv) quem são os seus acionistas, e (v) as informações econômico-financeiras dos últimos 3 (três) anos, entre outras. Por todo o exposto, as informações sobre o policitante afiguram-se como um elemento importantíssimo, porque é de interesse de todos os agentes do mercado a identificação do ofertante, sobretudo em vista da possibilidade de ofertas anônimas, bastante comuns na Europa até meados do século XX, como foi o caso da proposta da Fiat pela Simca, em cujo instrumento de oferta pública identificou-se apenas como um "acionista minoritário". Essa regra de "full and fair disclosure" tem por objetivo diminuir ao máximo a assimetria de informação no mercado e suas implicações danosas já bastante conhecidas. A falta de qualquer desses elementos dá à CVM a prerrogativa de suspender a oferta, o que equivale à sua extinção, já que a sua nova veiculação consistirá em nova proposta. A falta de entrega de documentação à CVM também pode importar à suspensão da oferta, como dispõe o art. $9^{\circ}, \S 1^{\circ}$, I, da Lei n $^{\circ} 6.385 / 76$ " SCALZILLI, João Pedro. Mercado de Capitais, Ofertas Hostis e Técnicas de Defesa. São Paulo: Quartier Latin, 2015. p. 147 e 148.

"Se a oferta envolver permuta, o instrumento deverá conter, além dos elementos referidos no item 2 supra, informações sobre os valores mobiliários oferecidos em permuta e as companhias emissoras desses valores. No uso da faculdade que lhe foi atribuída pelo parágrafo único do artigo 259 da LSA, a CVM determinou que o instrumento da oferta de permuta, sem prejuízo de outras informações por ela consideradas necessárias, contenha: (i) as informações sobre a relação de troca, a quantidade, espécie e classe dos valores mobiliários ofertados, os direitos legais e estatutários conferidos por tais valores, seu histórico de negociação nos últimos doze meses e o tratamento a ser dado às eventuais frações decorrentes da relação de troca; e (ii) informações sobre a companhia emissora dos valores mobiliários ofertados, na mesma forma exigida para a distribuição de valores mobiliários (Instrução CVM no 361, art. 33, § 2º'”. LAMY FILHO, Alfredo; PEDREIRA, José Luiz Bulhões (Coord.). Direito das companhias. 2.ed. atual. refor. Rio de Janeiro: GEN, Forense, 2017,. p. 1488.

${ }^{85}$ Art. $5^{\circ}$ Após a publicação do instrumento de OPA, nos termos do art. 11, sua modificação ou revogação será admitida: I - em qualquer modalidade de OPA, independentemente de autorização da CVM, quando se tratar de modificação por melhoria da oferta em favor dos destinatários, ou por renúncia, pelo ofertante, a condição por ele estabelecida para a efetivação da OPA; II - quando se tratar de OPA sujeita a registro, mediante prévia e expressa autorização da CVM, observados os requisitos do $\$ 2^{\circ}$ deste artigo; ou III - quando se tratar de OPA não sujeita a registro, 
teoria da imprevisão, ao estabelecer a possibilidade, por meio de decisão da referida autarquia, de revogação ou modificação da proposta caso tenha ocorrido "alteração substancial, posterior e imprevisível, nas circunstâncias de fato existentes quando do lançamento da OPA, acarretando aumento relevante dos riscos assumidos pelo ofertante, inerentes à própria $O P A^{,, 86}$.

Outra exigência legal, estabelecida no caput do art. 257 da LSA, é a necessidade de participação de instituição financeira, responsável por garantir as obrigações assumidas pelo ofertante, mesmo em casos de permuta.

Caracterizada pela sua natureza de proposta indistinta, isto é, direcionada a todo e qualquer titular de ações da classe e espécie desejadas pelo ofertante, e pela sua publicidade, a oferta pública para aquisição de controle tem também como um dos seus requisitos essenciais a publicação, que servirá não só para dar ciência aos oblatos, como também para

independentemente de autorização da CVM, em estrita conformidade com os termos e condições previstos no respectivo instrumento. $\S 1^{\circ}$ Será ainda lícito ao ofertante desistir da OPA para cancelamento de registro e da OPA por aumento de participação, na hipótese de revisão do preço da oferta por força do procedimento previsto no art. 4o -A da Lei 6.404, de 1976, aplicando-se, em tais hipóteses, respectivamente, as regras dos arts. 24, inciso IV, e 28 desta Instrução. $\S 2^{\circ} \mathrm{Na}$ hipótese prevista no caput, inciso II, o pedido de modificação ou revogação de OPA: I - deverá ser informado ao público, pela mesma via utilizada para divulgação da OPA; II - acarretará a suspensão do prazo do edital, se estiver em curso; III - só será acolhido caso: a) a juízo da CVM, tenha havido alteração substancial, posterior e imprevisível, nas circunstâncias de fato existentes quando do lançamento da OPA, acarretando aumento relevante dos riscos assumidos pelo ofertante, inerentes à própria OPA; e b) o ofertante comprove que os atos e negócios jurídicos que tenham determinado a realização da OPA ficarão sem efeito se deferida a revogação; IV presumir-se-á deferido se não houver manifestação da CVM no prazo de 10 (dez) dias, contados do protocolo. $\$ 3^{\circ} \mathrm{A}$ modificação da OPA exigirá publicação de aditamento ao edital, com destaque para as modificações efetuadas e com a indicação da nova data para realização do leilão, a qual deverá observar os seguintes prazos: I - prazo mínimo de 10 (dez) dias, nos casos de aumento do preço da oferta ou renúncia a condição para efetivação da OPA, ou 20 (vinte) dias, nos demais casos, contados da publicação do aditamento; II - prazo máximo de 30 (trinta) dias contados da publicação do aditamento ou 45 (quarenta e cinco) dias contados da publicação do edital, o que for maior. $\$ 4^{\circ}$ A revogação da OPA deverá ser divulgada pela mesma via utilizada para divulgação da OPA. $\$ 5^{\circ}$ Em qualquer das hipóteses previstas no caput, cópia do aditamento ao edital deverá ser enviada à CVM na data de sua publicação.

${ }^{86}$ SCALZILLI, João Pedro. Mercado de Capitais, Ofertas Hostis e Técnicas de Defesa. São Paulo: Quartier Latin, 2015. p. 152. 
estabelecer o marco temporal inicial dos efeitos da proposta ${ }^{87}$. Assim estabelece o art. 11 da Instrução CVM n. ${ }^{\circ}$ 361/02:

"Art. 11. O instrumento de OPA deverá ser publicado, sob a forma de edital nos jornais de grande circulação habitualmente utilizados pela companhia objeto, observando-se o prazo máximo de 10 (dez) dias, após a obtenção do registro na CVM, quando este for exigível.

§1o Da publicação do instrumento da OPA constará, ainda, se for o caso, a data do deferimento do pedido de registro da OPA na CVM, com a informação, em destaque, de que o deferimento do pedido de registro da OPA não implica, por parte da CVM, garantia da veracidade das informações prestadas, julgamento sobre a qualidade da companhia objeto ou o preço ofertado pelas ações objeto da OPA.

$\S 2^{\circ} \mathrm{O}$ edital deverá ser também encaminhado ao diretor de relações com investidores da companhia objeto, para que este o divulgue imediatamente ao mercado, por meio de sistema eletrônico disponível na página da CVM na rede mundial de computadores, ficando ainda disponível a eventuais interessados, no mínimo, na CVM, na bolsa de valores ou na entidade do mercado de balcão organizado em que deva ser realizado o leilão, no endereço do ofertante, na sede da instituição intermediária e da companhia objeto, bem como acessível na rede mundial de computadores, no endereço eletrônico da companhia objeto, se esta o possuir."

A proposta, ainda que tenha por características a irrevocabilidade e irretratabilidade, poderá ser alterada na hipótese do art. $261, \S 1^{\circ}$ da LSA que disciplina ser "facultado ao ofertante melhorar, uma vez, as condições de preço ou forma de pagamento, desde que em porcentagem igual ou superior a 5\% (cinco por cento) e até 10 (dez) dias antes do término do prazo da oferta; as novas condições se estenderão aos acionistas que já tiverem aceito a oferta." Trata-se, portanto, de mera melhoria à proposta anteriormente estabelecida, a fim de atrair mais acionista à sua adesão.

Ademais, os oblatos podem alterar a sua aceitação em outra situação, qual seja, quando da ocorrência de uma oferta concorrente. Em tal conjuntura, as aceitações outrora manifestadas perdem seus efeitos, e geram ao ofertante inicial, a possibilidade de prorrogar o prazo da sua oferta para adequá-la ao da oferta concorrente. É o que estabelece o $\S 2^{\circ}$ do art. 262 da LSA:

"Nos termos do $\S 1^{\circ}$ do artigo 261 da LSA, acima comentado, poderá o primeiro ofertante melhorar sua oferta original para competir com a oferta concorrente.

\footnotetext{
${ }^{87}$ Ressalta-se ainda, que, por força do parágrafo único do art. 258 , LSA, o ofertante terá vinte e quatro horas, contadas da primeira publicação do edital, para comunicar o lançamento da oferta à CVM.
} 
Tais faculdades deverão ser exercidas mediante publicação de um aditamento ao instrumento da oferta, exigido o prévio registro da melhoria na CVM, se a oferta melhorada envolver a permuta de valores mobiliários" $" 88$.

Mais ainda, embora "não esteja previsto na legislação, o ofertante originário pode apresentar contraproposta, assim como também o pode o ofertante concorrente, medidas essas que podem ocorrer, sucessivamente, inúmeras vezes, para se garantir a igualdade de oportunidade entre os ofertantes" $"$.

Ao final do prazo das aceitações, a instituição financeira será responsável por comunicar o resultado da oferta à CVM e, mediante publicação na imprensa, àqueles que aceitaram a proposta.

Por fim, cabe esclarecer que a CVM tem poderes para disciplinar a negociação dos valores mobiliários da companhia-alvo, podendo, inclusive, suspender a oferta em razão de irregularidade (art. 263 da LSA e art. $9^{\circ}$, $\S 1^{\circ}$, I, Lei n. ${ }^{\circ} 6.385 / 76$ ) ou até cancelá-la em caso de vício insanável (art. $4^{\circ}, \S 2^{\circ}$, Instrução CVM n. $\left.{ }^{\circ} 361 / 02\right)$.

Vistos os aspectos procedimentais da OPA para aquisição do poder de controle no ordenamento jurídico brasileiro, podemos adentrar na atuação do conselho de administração nesta conjuntura.

\footnotetext{
${ }^{88}$ LAMY FILHO, Alfredo; BULHÕES PEDREIRA, José Luiz. Direito das Companhias. p. 1489.

${ }^{89}$ SCALZILLI, João Pedro. Mercado de Capitais, Ofertas Hostis e Técnicas de Defesa. São Paulo: Quartier Latin, 2015. p. 155.
} 


\section{CAPÍTULO 5. A ATUAÇÃO DO CONSELHO DE ADMINISTRAÇÃO NAS TOMADAS HOSTIS}

Conforme já elucidamos, as ofertas hostis podem ser benéficas ou prejudiciais à companhia, sendo impossível uma análise abstrata da sua conveniência. Neste cenário, o conselho de administração ocupa uma posição bastante ingrata.

Por um lado, não se pode negar que haverá um potencial conflito de interesses por parte dos administradores, uma vez que, concretizada a tomada de controle, o novo controlador muito provavelmente irá alterar a composição do conselho de administração no máximo que puder. Nessa perspectiva, poder-se-ia afirmar que este órgão social não pudesse atuar de forma alguma nessa situação, visto haver interesse conflitante ${ }^{90}$.

Por outro lado, também não se pode refutar de plano que ninguém, ainda mais em companhias de capital disperso, possui maiores informações sobre a companhia do que o seu conselho de administração. Além disso, o conflito de interesses mencionado acima tem caráter potencial, isto é, não necessariamente a atuação do conselho de administração será fundamentada na mera busca pela manutenção de seus cargos. Não se podendo presumir a má-fé sem expressa previsão em lei. É muito possível que o conselho de administração entenda que a figura do adquirente representa uma ameaça ao

\footnotetext{
90 "O ponto mais controvertido da regulação das OPAs para aquisição de controle refere-se ao poder dos administradores da companhia objeto de se valerem de mecanismos de defesa com o objetivo de frustrarem tais ofertas. Em outras palavras, a discussão relaciona-se à alocação do poder de decisão no que concerne à oferta entre a administração e os acionistas destinatários. (...) Apesar de a Lei das S.A. conter dispositivos disciplinando a OPA para aquisição de controle, não existem no ordenamento jurídico brasileiro regras claras estabelecendo deveres, responsabilidades e limites de atuação dos administradores diante dessas ofertas, notadamente no que se refere às táticas de defesa que eles podem utilizar contra elas. Seria importante, para se prevenir as situações anteriormente aludidas de conflito de interesses entre os acionistas e os administradores que comumente emergem diante das ofertas públicas hostis para aquisição de controle, que nosso ordenamento adotasse normas específicas garantindo aos acionistas o poder de decisão final a respeito da aceitação da OPA, não deixando margem para que a administração da companhia objeto tome medidas que visem a frustrar a soberania de decisão dos acionistas". EIZIRIK, Nelson; HENRIQUES, Marcus de Freitas; VIEIRA, Juliana Botini Hargreaves. O Cômite de Aquisições e Fusões: Versão Brasileira do Takeover Panel. In: KUYVEN, Luiz Fernando Martins (Coord.). Temas essenciais de direito empresarial. São Paulo: Saraiva, 2012. p. 891 e 892.
} 
interesse social. Assim, sob este ponto de vista, pode-se arguir que o conselho de administração, se dessa forma compreender a oferta formulada, deverá, nos limites estabelecidos pela lei e pelo estatuto social da companhia, atuar de forma a frustrar a oferta hostil.

Conforme veremos, independentemente da posição adotada, a única conclusão inafastável que se pode extrair do nosso ordenamento jurídico é de que, ao cabo, a decisão pela aceitação ou não da oferta caberá exclusivamente aos acionistas, tendo o conselho de administração, no ordenamento pátrio, ferramentas muito mais restritas do que as que se encontram em outros ordenamentos jurídicos, como, por exemplo, nos EUA. Todavia, conforme abordaremos, isso não significa necessariamente que o conselho de administração deva ficar inerte.

Feitas essas breves considerações, percebe-se que, para que adentremos na análise da atuação dos administradores nas tomadas hostis, é preciso entender o instituto do conflito de interesses. Todavia, para que se compreenda tal instituto é preciso analisar o interesse que deverá guiar os atos dos administradores, qual seja, o interesse social. Razão pela qual passaremos a tecer alguns breves comentários acerca deste relevantíssimo conceito societário, para, então, adentrar na mencionada problemática do conflito de interesses que pautará toda a discussão do objeto do presente trabalho.

\subsection{O Interesse Social}

Como vimos, aos administradores são delegados poderes por parte dos acionistas, colocando-os, por conseguinte, em uma posição privilegiada que os permitirá acesso a informações sensíveis e a possibilidade de tomar decisões significativas que afetarão patrimônio de tais investidores. Tal fato gerará os já delineados deveres fiduciários que balizarão a conduta dos 
administradores, uma vez que " $a$ todo poder correspondem deveres $e$ responsabilidades próprias" 91 .

Não é por diverso motivo que o art. 116 da $\mathrm{LSA}^{92}$ estabelece que o acionista controlador deve usar o poder de controle que detém para fazer com que a companhia realize seu objeto e cumpra sua função social, tendo obrigações inclusive perante os minoritários, empregados da companhia e a comunidade em que atua. $\mathrm{O}$ mesmo se dá para os administradores em virtude do art. 154, LSA. Assim, surge o instituto do interesse social cuja função será aferir qual o interesse deve ser perseguido e protegido pelos controladores e administradores.

Em outras palavras, deve o administrador atuar visando única e exclusivamente a maximização do valor das ações da companhia, a manutenção dos empregos daqueles nela trabalham ou a preservação do meio-ambiente e da comunidade em que a companhia atua? Tal norte será dado justamente pelo interesse social que será, por sua vez, exercido por meio do direito do voto, seja nas assembleias gerais, seja nas decisões deliberadas nas reuniões do conselho de administração, ou até mesmo no âmbito do cotidiano da administração dos negócios da companhia pela diretoria. Assim, aquele que exercer o direito de voto terá o poder de guiar a companhia na direção da concretização de seu interesse social, como também de distanciá-la deste.

Afere-se, portanto, desde já, que o poder de controle e, consequentemente, sua delegação, se qualificará como um poder-dever, e

\footnotetext{
${ }^{91}$ COMPARATO, Fábio Konder; SALOMÃO FILHO, Calixto. O poder de controle na sociedade anônima. $4^{\mathrm{a}}$ ed. Rio de Janeiro: Forense, 2005. p. 363.

${ }^{92}$ Art. 116. Entende-se por acionista controlador a pessoa, natural ou jurídica, ou o grupo de pessoas vinculadas por acordo de voto, ou sob controle comum, que:

a) é titular de direitos de sócio que lhe assegurem, de modo permanente, a maioria dos votos nas deliberações da assembléia-geral e o poder de eleger a maioria dos administradores da companhia; $\mathrm{e}$

b) usa efetivamente seu poder para dirigir as atividades sociais e orientar o funcionamento dos órgãos da companhia.

Parágrafo único. O acionista controlador deve usar o poder com o fim de fazer a companhia realizar o seu objeto e cumprir sua função social, e tem deveres e responsabilidades para com os demais acionistas da empresa, os que nela trabalham e para com a comunidade em que atua, cujos direitos e interesses deve lealmente respeitar e atender.
} 
que será exercido pelo direito de voto que, por sua vez, será adequadamente utilizado quando se nortear pelo interesse social. Para tanto, diversas teorias foram elaboradas que buscaram delinear qual seria o interesse social. Dentre elas, destacam-se a teorias contratualista e institucionalista que passaremos a analisar.

\subsubsection{As Teorias do Interesse Social}

A teoria contratualista defende que o interesse social, isto é, o interesse da companhia, nada mais é do que o interesse daqueles que nela depositaram seu patrimônio, ou seja, o de seus acionistas. Assim, o interesse social corresponderia apenas à busca pela maximização da riqueza dos acionistas por meio da valorização do valor de suas ações e da geração e posterior distribuição de lucros. É o que se dá, por exemplo, em países como a Itália que adota a concepção contratualista ${ }^{93}$.

Em polo antagônico, encontra-se a concepção institucionalista. Segundo esta vertente, não se poderia cogitar que o interesse social se reduzisse apenas ao interesse dos acionistas, devendo este abranger também o interesse de outros stakeholders, como, por exemplo, os interesses dos empregados da companhia, da comunidade em que atua, do Estado em que está se localiza, dentre outros ${ }^{94}$ e 95 . Haveria, portanto, um interesse público subjacente que deve ser respeitado por aqueles que controlam e comandam as companhias ${ }^{96}$.

\footnotetext{
${ }^{93}$ SALOMÃO FILHO, Calixto. O novo direito societário. $3^{\mathrm{a}}$ ed. São Paulo: Malheiros. p. 59-60.

${ }^{94}$ SADDI, Jairo. Conflito de Interesses no Mercado de Capitais. In CASTRO, Rodrigo R. Monteiro de; ARAGÃO, Leandro Santos de (Coord.). Sociedade Anônima. São Paulo: Quartier Latin, 2007, p. 344.

${ }^{95}$ As novas roupagens do institucionalismo e do contratualismo favorecem o aparecimento de teses conciliadoras. O elo é a noção de responsabilidade social. Tal ideia demonstra o reconhecimento de interesses externos à companhia. Por outro lado, há uma tendência a observarse a responsabilidade social, ainda que não pelos seus fins, mas para garantir maior rentabilidade à empresa, pois a prática de ações de responsabilidade social é benéfica à imagem e aos negócios da empresa" (RIBEIRO, Renato Ventura. Direito de Voto nas Sociedades Anônimas. São Paulo: Quartier Latin, 2009. p. 120).

96 "Concepção da 'empresa em si', em que os controladores detêm o poder não para si mesmos, mas sim para servir ao interesse público, representando a empresa uma organização que transcende
} 
Conforme leciona Walther Rathenau, "a empresa não é mais hoje uma estrutura exclusiva dos interesses do Direito Privado, mas muito mais, tanto individualmente como em seu conjunto, um fator da economia nacional, pertencente à totalidade, que ainda carrega consigo em razão de sua origem, por direito ou não, traços de Direito Privado de uma pura empresa lucrativa e, assim, criou uma nova situação jurídica"97.

Desse modo, não só o interesse dos acionistas da companhia, como também os dos seus administradores, credores, fornecedores e até mesmo os da comunidade em que está inserida, deverão ser ponderados de tal maneira que todos estes interesses possam ser, ao fim, equilibradamente considerados $^{98,99}$.

Sob a ótica desta vertente, percebe-se que a administração restaria fortalecida em detrimento da assembleia geral. Pois, enquanto esta buscaria apenas o interesse dos acionistas, aquela protegeria a concretização da função institucional da companhia.

Por óbvio, ambas as concepções não se mantiveram inalteradas, tendo sido modificadas de forma a se adaptar às mudanças que ocorreram ao longo dos tempos.

Assim, a partir da concepção original da teoria contratualista, desenvolveu-se o denominado "contratualismo moderno" que defende que os interesses dos futuros sócios também devem ser observados ${ }^{100}$. Esta é a concepção atualmente adotada pelo sistema jurídico norte-americano.

os meros interesses dos sócios que a compõe. COMPARATO, Fábio Konder; SALOMÃO FILHO, Calixto. O poder de controle na sociedade anônima. $4^{\mathrm{a}}$ ed. Rio de Janeiro: Forense, 2005. p. 366.

${ }^{97}$ RATHENAU, Walther. Do Sistema Acionário - uma análise negocial. Tradução e introdução de Nilson Lautenschleger Jr. Revista de Direito Mercantil, n 128, a. XLI, p. 214, out./dez. 2002

${ }^{98}$ BARRETO, Júlio. O Conflito de Interesses entre a Companhia e seus Administradores. Rio de Janeiro: Renovar, 2009, p. 105.

99 Prova de tal preocupação pode ser encontrada em diversas passagens da LSA, como, por exemplo, a necessidade de aprovação dos debenturistas para aprovação de incorporação, fusão ou cisão da companhia emissora (art. 231, LSA) e a possibilidade de previsão estatutária de participação de representantes dos empregados no conselho de administração (§ único, art. 140, LSA).

${ }^{100}$ RIBEIRO, Renato Ventura. Direito de Voto nas Sociedades Anônimas. São Paulo: Quartier Latin, 2009, p. 113-119. 
O institucionalismo também foi alterado dando origem ao chamado "institucionalismo organizativo". Dessa forma, a então concepção institucionalista buscou ter maior efetividade a partir da aferição de qual tipo de empresa seria mais adequada aos interesses dos stakeholders.

Como se sabe, no mundo jurídico há algo que sempre acontece. Alguém, observando um determinado problema, cria uma teoria. Em seguida, outra pessoa vem e discorda totalmente da primeira teoria criando uma segunda teoria completamente antagônica à primeira. Por fim, surge um terceiro que, percebendo que ambas as teorias têm seus pontos positivos e negativos, resolve criar uma terceira teoria que adota parte de cada uma das outras duas teorias.

Em relação ao interesse social não foi diferente. A partir destas duas concepções, quais sejam, institucionalista e contratualista, adveio a denominada "teoria mista" na qual o interesse social estaria concretizado se o lucro fosse maximizado através de decisões que atendam aos diferentes interesses de cada um dos stakeholders envolvidos. Assim, o interesse social da companhia seria nada mais que o resultado da ponderação dos interesses dos stakeholders em conjunto com os dos acionistas.

Tal teoria decorreria do fato de, havendo pulverização acionária, o acionista seria um investidor, e não um empresário, levando-o a buscar a valorização de suas ações e dos rendimentos delas decorrentes e não os demais aspectos de caráter empresarial ligados à companhia. Assim sendo, o que haveria de comum entre os interesses dos stakeholders e dos acionistas seria a maximização dos lucros, objetivando a manutenção das atividades da companhia de forma competitiva e eficiente ${ }^{101}$.

\footnotetext{
101 “Assim, podem ser identificados certos atores sociais - aqui no sentido de stakeholders - que participam da esfera de atuação da empresa aberta. Esses atores, conforme visto, são agentes econômicos, racionais, com interesses explícitos de ver crescer os seus investimentos mobiliários. Ou seja, o único interesse real do acionista não controlador é aumentar seus benefícios econômicos ao longo do tempo, seja através do aumento do valor da sua ação, seja através da distribuição de dividendos e bonificações. Um segundo argumento define de forma igualmente definitiva os stakeholders, não quanto ao fim do aumento do valor das ações, mas quanto à forma de se atingir tal objetivo". SADDI, Jairo. Conflito de Interesses no Mercado de Capitais. In CASTRO, Rodrigo
} 
Por óbvio, é impossível que, em todas e quaisquer situações, atendamse a todos os interesses envolvidos, o que fará com que, a depender do caso concreto, alguns interesses sejam priorizados em detrimento de outros. Por tal motivo, há a necessidade de se avaliar e ponderar casuisticamente os diversos interesses envolvidos, de forma a aferir qual deve ser priorizado.

Em relação ao objeto do presente estudo, percebe-se que, a depender de qual vertente se adota, o papel do conselho de administração nas tomadas hostis será fortemente afetado, uma vez que será justamente o interesse social que legitimará ou não a propositura ou adoção de uma medida defensiva.

Em outras palavras, se adotada a corrente contratualista é provável que a atuação do administrador seja mais voltada para a negociação de termos que gerem a maximização do preço ofertado. Por sua vez, aderindo-se à corrente institucionalista, é possível que a atuação do administrador busque frustrar a oferta hostil que represente, na sua visão, uma ameaça ao interesse de outros stakeholders. Assim, cumpre analisar a inserção de tais concepções no ordenamento jurídico brasileiro.

\subsubsection{O Interesse Social no Ordenamento Jurídico Brasileiro}

A definição de interesse social foi e continua sendo alvo de grandes debates. Afora discussões de caráter meramente ideológico, o que se pode extrair como consenso é que o Código Civil apresenta um viés mais contratualista, enquanto a LSA denota um caráter mais institucionalista.

$\mathrm{O}$ art. 981 do $\mathrm{CC}$ exige, por exemplo, a pluralidade de pessoas ${ }^{102}$, a organização em torno de uma atividade econômica ${ }^{103}$ e a reciprocidade de

R. Monteiro de; ARAGÃO, Leandro Santos de (Coord.). Sociedade Anônima. São Paulo: Quartier Latin, 2007, p. 347.

${ }^{102}$ Algo não necessariamente exigido pela corrente institucionalista, uma vez que aceita sociedades unipessoais, mesmo que em caráter superveniente ou transitório, além das subsidiárias integrais.

${ }^{103}$ Diversamente da exigência de criação de uma forma organizativa. 
obrigações entre os sócios ${ }^{104}$. Todos esses aspectos dão uma forte conotação contratualista a tal diploma normativo.

Por outro lado, inúmeras são as disposições da LSA que denotam um viés institucionalista. É o caso, por exemplo, dos arts. 116, § único ${ }^{105}, 115$, $\S 4^{\text {o106 }}$, e $154^{107}$ da LSA. De acordo com tais dispositivos, os deveres neles previstos não se resumem à maximização da riqueza, devendo ser observados ainda os interesses dos demais acionistas, dos empregados da companhia e da comunidade em que esta atua, bem como as exigências do bem público e da função social da empresa ${ }^{108}$.

Ocorre que, na prática, são diversas as decisões que podem fazer com que o interesse daquele que exerce o direito de voto na matéria a ser deliberada esteja em conflito ou potencialmente em conflito com o interesse social, cuja caracterização, como vimos, não é uníssona ${ }^{109}$. É o que ocorre,

\footnotetext{
${ }^{104}$ Nesse caso, a obrigação é para com os demais sócios, e não relativa à sociedade.

105 "O acionista controlador deve usar o poder com o fim de fazer a companhia realizar o seu objeto e cumprir sua função social, e tem deveres e responsabilidades para com os demais acionistas da empresa, os que nela trabalham e para com a comunidade em que atua, cujos direitos e interesses deve lealmente respeitar e atender".

106 “A deliberação tomada em decorrência do voto de acionista que tem interesse conflitante com o da companhia é anulável; o acionista responderá pelos danos causados e será obrigado a transferir para a companhia as vantagens que tiver auferido".

${ }_{107}$ Art. 154. O administrador deve exercer as atribuições que a lei e o estatuto lhe conferem para lograr os fins e no interesse da companhia, satisfeitas as exigências do bem público e da função social da empresa.

$\S 1^{\circ} \mathrm{O}$ administrador eleito por grupo ou classe de acionistas tem, para com a companhia, os mesmos deveres que os demais, não podendo, ainda que para defesa do interesse dos que o elegeram, faltar a esses deveres.

$\S 2^{\circ}$ É vedado ao administrador:

a) praticar ato de liberalidade à custa da companhia;

b) sem prévia autorização da assembléia-geral ou do conselho de administração, tomar por empréstimo recursos ou bens da companhia, ou usar, em proveito próprio, de sociedade em que tenha interesse, ou de terceiros, os seus bens, serviços ou crédito;

c) receber de terceiros, sem autorização estatutária ou da assembléia-geral, qualquer modalidade de vantagem pessoal, direta ou indireta, em razão do exercício de seu cargo.

$\S 3^{\circ}$ As importâncias recebidas com infração ao disposto na alínea $\mathrm{c}$ do $\S 2^{\circ}$ pertencerão à companhia.

$\S 4^{\circ} \mathrm{O}$ conselho de administração ou a diretoria podem autorizar a prática de atos gratuitos razoáveis em benefício dos empregados ou da comunidade de que participe a empresa, tendo em vista suas responsabilidades sociais.

${ }^{108}$ Concordamos, entretanto, com Calixto Salomão Filho, para quem atualmente há, na teoria um institucionalismo de princípios, enquanto o que se verifica na prática é um contratualismo de fato. (SALOMÃO FILHO, Calixto. O novo direito societário. $3^{\mathrm{a}}$ ed. São Paulo: Malheiros. p. 36-38).

${ }^{109}$ Eduardo Munhoz aponta que é dificuldade de se estabelecer a priori quais interesses devem ser protegidos em caso de conflito que torna difícil o preenchimento desse hiato legislativo. MUNHOZ, Eduardo Secchi. Empresa Contemporânea e direito societário. São Paulo: Juarez de Oliveira, 2002. p. 42.
} 
por exemplo, nas ofertas hostis, nas quais os membros do conselho de administração provavelmente perderão seus cargos caso esta obtenha sucesso. Nessas situações surge o chamado "conflito de interesses", tema este diretamente relacionado ao objeto do presente estudo e que passaremos a analisar.

\subsection{O Conflito de Interesses}

A caracterização de um conflito de interesses depende da contraposição de um interesse pessoal em relação ao interesse social, instituto acima delineado. Em tais situações, um desses interesses não pode ser concretizado sem que o outro seja prejudicado. Exige-se, por conseguinte, que um dos dois seja sacrificado em benefício do outro.

A ocorrência do conflito de interesses pode se dar em dois âmbitos. O primeiro seria no plano dos acionistas, conforme prevê o art. $115, \mathrm{LSA}^{110}$. O segundo plano se daria no plano da administração da companhia, como estabelecido no art. 154 da LSA.

A ratio por trás da vedação ao conflito de interesses se dá pela possibilidade de supressão do interesse social em favor de um interesse meramente pessoal. Em outras palavras, o conflito de interesses só ganha relevância quando passível de gerar dano à companhia, ou seja, por afetar o interesse social negativamente.

\footnotetext{
110 "Art. 115. O acionista deve exercer o direito a voto no interesse da companhia; considerar-se-á abusivo o voto exercido com o fim de causar dano à companhia ou a outros acionistas, ou de obter, para si ou para outrem, vantagem a que não faz jus e de que resulte, ou possa resultar, prejuízo para a companhia ou para outros acionistas.

$\S 1^{\circ}$ o acionista não poderá votar nas deliberações da assembléia-geral relativas ao laudo de avaliação de bens com que concorrer para a formação do capital social e à aprovação de suas contas como administrador, nem em quaisquer outras que puderem beneficiá-lo de modo particular, ou em que tiver interesse conflitante com o da companhia.

$\S 2^{\circ}$ Se todos os subscritores forem condôminos de bem com que concorreram para a formação do capital social, poderão aprovar o laudo, sem prejuízo da responsabilidade de que trata o $\S 6^{\circ}$ do artigo $8^{\circ}$.

$\S 3^{\circ} \mathrm{o}$ acionista responde pelos danos causados pelo exercício abusivo do direito de voto, ainda que seu voto não haja prevalecido.

$\S 4^{\circ}$ A deliberação tomada em decorrência do voto de acionista que tem interesse conflitante com o da companhia é anulável; o acionista responderá pelos danos causados e será obrigado a transferir para a companhia as vantagens que tiver auferido“.
} 
O grande debate, contudo, surge da natureza deste conflito. Por um lado, há a doutrina majoritária que defende que o conflito de interesses que ensejará proteção deve ser substancial, isto é, "se o dano, ainda que potencial, não se verifica, não há razão para se dizer que a atuação foi resultado de um conflito de interesses" $" 111$. Assim, entende tal corrente que a "a existência de duplicidade de interesses não é caracterizadora de conflito de interesses. A relação bilateral não induz o conflito de interesses" ${ }^{\prime 12}$.

Dessa forma, a análise da adequação da decisão tomada deve ser ex post, ou seja, não se pune o conflito de interesses formal impossibilitando o exercício do direito de voto daquele que esteja abstratamente conflitado. Exige-se, portanto, que seja analisado se, em virtude daquela decisão, houve de fato a sobreposição do interesse pessoal em prejuízo do interesse social. É dizer, só haverá responsabilidade se, em decorrência de tal sobreposição egoística, a companhia tiver sofrido danos.

Por outro lado, há a corrente minoritária, atualmente defendida e adotada pela $\mathrm{CVM}^{113}$, que entende que tratando do conflito de interesses no plano da assembleia geral determinou que "o art. $115, \S 1^{\circ}$, ao determinar que o acionista fica impedido de votar nas deliberações em que tiver interesse conflitante com o da companhia, estabeleceu verdadeira hipótese de impedimento de voto, que pode ser controlada antes da deliberação, se houver evidência de que está em jogo algum interesse particular do acionista, que não é comum aos demais. O conflito se configura a partir da identificação desse interesse particular, independentemente da comprovação de prejuízo à companhia"114.

\footnotetext{
${ }^{111}$ LAMY FILHO, Alfredo; PEDREIRA, José Luiz Bulhões (Coord.). Direito das companhias. 2.ed. atual. refor. Rio de Janeiro: GEN, Forense, 2017,. p. 841

${ }^{112}$ LAMY FILHO, Alfredo; PEDREIRA, José Luiz Bulhões (Coord.). Ibid.. p. 840

${ }^{113}$ Casos Duratex-Satipel (processo RJ 2009-5811, rel. SEP, j. 28.07.2009), Tractebel (processo RJ 2009-13179, rel. Dir. Alexsandro Broedel Lopes, j. 09.09.2010), Eletrobras (processo sancionador RJ 2013-6635, rel. Dir. Luciana Dias, j. 26.05.2015) e Eneva (processo RJ 20155021, rel. Dir. Pablo Waldemar Renteria, j. 25.08.2015).

${ }^{114}$ Trecho do voto da ex-presidente da CVM Maria Helena Santana, no âmbito do caso Tractebel (processo RJ 2009-13179, rel. Dir. Alexsandro Broedel Lopes, j. 09.09.2010).
} 
O mesmo se aplicaria às deliberações proferidas no âmbito do conselho de administração. Dessa maneira, entendendo-se por formal a natureza do conflito de interesses, a análise da regularidade do exercício do direito de voto proferido seria ex ante, diferentemente do que ocorreria caso o conflito fosse substancial o que faria com que tal análise se desse ex post. Sendo formal a natureza do conflito de interesses, aqueles que tiver interesse na matéria deliberada deverá se abster de votar sob pena de receber uma sanção.

Por maior que seja o respeito que temos pelos defensores da teoria formal, acreditamos que esta não foi prevista na LSA. De fato, o $\S 1^{\circ}$ do art. 115 da LSA, em sua interpretação literal, veda ao acionista votar em deliberações em que tiver interesse conflitante com o da companhia. Entretanto, o $\S 4^{\circ}$ do mesmo dispositivo determina que a "deliberação tomada em decorrência do voto de acionista que tem interesse conflitante com o da companhia é anulável".

Como se sabe, não existem palavras vazias na lei. Ademais, é notório o risco da geração de distorções por meio de interpretações meramente literais. Com isso, acreditamos que deva ser feita uma análise sistemática desses dispositivos. Assim, entendemos que a LSA não determina que o acionista estará a priori impedido de votar em tal conjuntura, mas sim que, caso vote, e seu voto seja determinante para a deliberação formada, tal deliberação poderá ser anulada posteriormente. Em outras palavras, o conflito seria substancial, pois a análise se daria ex post, não havendo razões, fora as hipóteses previstas expressamente em lei, para obstar o exercício do direito de voto afora às hipóteses expressas em lei ${ }^{115}$.

Com isso, entendemos que, em relação às ofertas hostis, as decisões do controlador minoritário e dos administradores que busquem frear a oferta não podem ser obstadas a priori, devendo ser comprovado que tais

\footnotetext{
115 As exceções estariam, entretanto, nas hipóteses de aprovação pelo acionista do "laudo de avaliação de bens com que concorrer para a formação do capital social e à aprovação de suas contas como administrador" (art. 115, $1^{\circ}$ da LSA).
} 
condutas geraram dano à companhia e que foram baseadas em interesses de caráter meramente pessoal. Somente assim, poder-se-ia analisar tais deliberações e eventualmente anulá-las.

Exposto o debate acerca do conflito de interesses, cabe, por ora, esclarecer os dois dispositivos legais referentes a tal instituto que são relevantes para o objeto do presente estudo.

Em primeiro lugar, o art. 156 da LSA veda ao administrador intervir em operação social quando estiver conflitado. Entende-se por "operação social" qualquer ato ou fato que envolva a companhia. Em outras palavras, deve a companhia ser parte da operação. ${ }^{116}$

Como já introduzido e conforme aprofundaremos mais adiante, os membros do conselho de administração, quando em face de uma oferta hostil, encontram-se em uma situação de potencial conflito de interesses, pois, caso o ofertante obtenha êxito e adquira o controle daquela companhia, sua primeira medida será alterar a composição de tal órgão social. O mesmo se dá em relação ao controlador minoritário, pois, tendo a oferta êxito, este não se verá mais titular do poder de controle, perdendo, consequentemente, o comando sobre a administração da companhia.

Assim, em qualquer conduta por parte dos conselheiros e/ou do controlador minoritário, no sentido de tentar induzir os acionistas a rejeitarem ou dificultarem o sucesso da oferta hostil, haverá sempre a possibilidade de tais conselheiros e/ou acionista estarem atuando em prol do seu próprio interesse, buscando permanecer nos seus cargos ou manter o seu poder de controle.

Por outro lado, não se pode refutar que ninguém possui maiores conhecimentos acerca daquela companhia do que os membros do conselho de administração, razão pela qual também é possível que, por meio de uma decisão de caráter negocial, eles entendam que a aquisição pelo ofertante representa uma ameaça ao interesse social.

\footnotetext{
${ }^{116}$ OIOLI, Erik Frederico. Oferta pública de aquisição do controle de companhias abertas. São
} Paulo: Quartier Latin, 2010. p. 210. 
À título de ilustração damos o seguinte exemplo: uma companhia aberta denominada XPTO S.A. tem um capital social composto apenas por ações ordinárias e um free float de $90 \%$, não possuindo nenhum acionista que detenha mais que 7\% do capital votante. Tal companhia investiu em projetos de longo prazo para o desenvolvimento de tecnologias ainda não divulgadas que, segundo estudos elaborados a pedido do conselho de administração, gerarão um altíssimo rendimento. Entretanto, em virtude destes significativos investimentos, a companhia passou a operar em baixa, algo que, na opinião dos conselheiros, baseada nos estudos solicitados, tem caráter meramente transitório.

Um indivíduo, que denominaremos meramente de Ofertante, observa que a XPTO S.A. possui um grande potencial e valiosos ativos, e, entendendo que a Companhia está sendo mal administrada resolve adquirir o controle da XPTO S.A., por meio de uma oferta pública, visto que sua alta dispersão acionária impossibilitaria uma negociação particular com cada acionista sem que o Ofertante incorresse em elevados custos.

Realizada a oferta pública, os membros do conselho de administração da XPTO S.A. buscam informações sobre os impactos que podem ser gerados pela oferta e o histórico do Ofertante. Assim, contratam uma empresa especializada que profere um parecer independente (fairness opinion). O resultado não só aponta que os planos do Ofertante impactaram negativamente os projetos de longo prazo em andamento, como também que o Ofertante é conhecido por adquirir empresas em dificuldades apenas para alienar seus ativos, o que, em diversos casos, levou à extinção de tais companhias.

Assim, reconhecendo na oferta uma ameaça, os membros do conselho de administração divulgam um relatório por meio de "aviso aos acionistas", expondo as razões pelas quais entendem que a oferta feita pelo Ofertante é prejudicial ao interesse social e deliberam convocar uma assembleia geral extraordinária para incluir no estatuto social da XPTO S.A. uma cláusula que determina que qualquer pessoa que, mediante operação isolada ou 
através de uma série de operações, adquira ou se torne titular, direta ou indiretamente, por qualquer meio, de $20 \%$ (vinte por cento) ou mais do capital votante, deverá realizar uma oferta pública para adquirir as ações dos demais acionistas. Cientes da relevante dispersão acionária, resolvem ainda os administradores realizar um pedido público de procuração para votar em nome dos acionistas em tal matéria. Por fim, preocupados com a dificuldade de atingir o quórum de instalação e com a proximidade do prazo da oferta, resolvem procurar a companhia YPTA S.A. para fazer uma oferta concorrente, que, por sua vez, aceita tal proposta, mas exige a celebração de um acordo que obrigará a Companhia a ceder parte dos direitos patrimoniais oriundos dos investimentos de longo prazo atualmente em andamento e que, segundo as informações obtidas através do parecer independente, encontram-se ameaçados pelo Ofertante.

Como se percebe, é possível que se trate ou não de uma companhia mal administrada, bem como é possível que os membros do conselho de administração estejam atuando tanto no exclusivo intuito de manter seus cargos quanto em prol do interesse social por meio da busca pela preservação da Companhia. Assim, ilustra-se o potencial conflito de interesses supramencionado.

A questão que remanesce, entretanto, é a possibilidade e a extensão da atuação do conselho de administração quando presente tal circunstância. Como vimos a atuação dos administradores em tomadas hostis carece de regulamentação expressa em lei:

"Mais especificamente, a referida legislação não prevê quaisquer dispositivos a respeito dos deveres e obrigações do conselho de administração da companhia ofertada nos casos de takeovers hostis, isto é, nos casos de uma OPA para aquisição de controle.

Com efeito, não há na referida legislação qualquer norma a respeito da postura que o conselho de administração deverá adotar nos casos em que a companhia para a qual trabalhem seja alvo de ofertas hostis. A título de exemplo, a legislação brasileira não prevê se os conselheiros de administração teriam a obrigação de disponibilizar aos acionistas relatório contendo sua opinião a respeito da oferta ou se estariam aptos a buscarem um terceiro que esteja interessado em lançar uma oferta concorrente.

A respeito dos deveres do conselho de administração, o aspecto da regulação de takeovers hostis que consideramos mais importante consiste na imposição de 
medidas anti-takeover com vistas a tentar bloquear a oferta hostil. Em relação a tal aspecto, nossa legislação é absolutamente omissa." 117

Dessa forma, com base no exemplo ilustrado acima, podemos fazer alguns questionamentos: (i) é lícita e/ou obrigatória a manifestação feita por meio de aviso de acionistas?; (ii) a convocação da AGE e o pedido público de procuração são devidos e/ou regulares?; (iii) poderia o conselho de administração ter procurado, sem a prévia anuência dos acionistas, um ofertante concorrente?; e (iv) podendo, poderiam tais administradores ter autorizado a diretoria da XPTO S.A. a celebrar o contrato com a YPTA S.A.?

As respostas para cada uma das perguntas acima não se encontra positivada expressamente em lei. Em razão desse vácuo legislativo, outras disposições da LSA e as demais fontes do Direito deverão ser utilizadas neste processo hermenêutico a fim de aferir a possibilidade e a extensão da atuação dos administradores quando confrontados com situações de ofertas hostis.

Assim, o que se pode extrair à luz das disposições atualmente positivadas na LSA é que, em tais situações, há uma aparente colisão entre alguns institutos já delineados no presente trabalho.

Em primeiro lugar, determina o art. 154 da LSA que o "administrador deve exercer as atribuições que a lei e o estatuto lhe conferem para lograr os fins e no interesse da companhia, satisfeitas as exigências do bem público e da função social da empresa". Nessa mesma linha, prevê o art. 155, II, LSA, que ao administrador é vedado "omitir-se no exercício ou proteção de direitos da companhia".

Em vista dos dispositivos transcritos acima, o primeiro questionamento que se faz é se, por força destes dispositivos a LSA delega

\footnotetext{
${ }^{117}$ FREITAS, Clarissa Figueiredo de Souza. Os poderes do conselho de administração para impor medidas defensivas contra ofertas hostis no direito comparado e na legislação brasileira. Revista de Direito Mercantil, Industrial, Econômico e Financeiro, São Paulo: Malheiros, v. 159/160, p. 127-141, jul./dez. 2011. p. 136.
} 
ou não aos administradores a atribuição de tentar proteger a companhia de ofertas hostis contrárias ao interesse social ou não.

Por outro lado, como já vimos, por força do art. 156, LSA, veda-se "ao administrador intervir em qualquer operação social em que tiver interesse conflitante com o da companhia".

Dessa forma, cumpre questionar se a oferta hostil é uma operação social e se pode ou o administrador nela intervir, nos limites legalmente permitidos, em face do potencial conflito de interesses apresentado em tais circunstâncias.

Por fim, resta uma última questão, qual seja, podendo o administrador atuar, dentro dos limites estabelecidos em lei ou pelo estatuto, a análise da legalidade de tal conduta deve se dar meramente pela ótica da business judgment rule?

Antes de analisar tais problemáticas, entretanto, em virtude da escassez legislativa que nosso sistema jurídico apresenta, tem-se por oportuno averiguar como se dá nos demais ordenamentos jurídicos a atuação dos administradores quando confrontados com uma tentativa de tomada hostil de controle.

\subsection{O Papel do Conselho de Administração nas Ofertas Hostis no Direito Comparado}

A possibilidade e a extensão da atuação do conselho de administração diferem de acordo com cada ordenamento jurídico.

Como se sabe, uma oferta pública se relaciona com diversos interesses que devem ser devidamente acomodados, de forma a reduzir eventuais distorções e desequilíbrios, a fim de assegurar aos acionistas informações 
adequadas para que possam aferir a inidoneidade da oferta, e aos ofertantes um tratamento equitativo ${ }^{118}$.

Entretanto, isto não é suficiente. É preciso também que se lide com a "tensão existente entre a opção pela preservação de um livre mercado de controle societário e o reconhecimento de que determinadas operações de transferência ou aquisição do controle podem trazer consequências para a companhia visada, que justificam a intervenção de administradores ou acionistas na operação" ${ }^{\text {119 }}$. Para tanto, duas são as formas de tratar a questão.

Em primeiro lugar, é possível determinar que os administradores somente atuem subordinados aos acionistas, cabendo a estes decidir sobre o êxito da oferta ${ }^{120}$. Dessa forma, um eventual conflito de interesses restaria afastado, pois a atuação da administração teria sido corroborada por uma decisão assemblear.

Entretanto, nessa perspectiva, a proteção conferida aos acionistas contra ofertantes oportunistas se verá reduzida. Sob tal modelo se vedaria em termos absolutos a atuação do conselho de administração, sem a prévia e expressa anuência dos acionistas reunidos em assembleia geral, de maneira a obstar que tal órgão atue sob o conflito de interesses. Adotam este modelo os países que entendem que, por mais que o conselho de administração seja quem mais conheça a companhia, o conflito de interesses seria prejudicial aos acionistas gerando aos administradores um dever de abstenção. O mesmo se daria em relação ao controlador minoritário.

Em outro modelo possível, alocar-se-ia nas mãos da administração ou até em um eventual controlador minoritário o poder de intervir na oferta,

\footnotetext{
${ }^{118}$ PRADO, Roberta Nioac. Oferta pública de ações obrigatória nas S.A. - tag along. São Paulo: Quartier Latin, 2005. p. 66.

${ }^{119}$ OIOLI, Erik Frederico. Oferta pública de aquisição do controle de companhias abertas. São Paulo: Quartier Latin, 2010. p. 108.

${ }^{120}$ Em relação ao controlador minoritário, sob essa vertente, por ter interesse na manutenção do seu poder de controle, caberia a ele se abster da deliberação a ser realizada pelos demais acionistas da companhia.
} 
desde que o façam no interesse social, e não por motivações de cunho meramente pessoal. Tal forma não significaria a exclusão do poder dos acionistas, visto serem estes os destinatários finais da oferta, mas sim que o poder de intervenção da administração se daria em conjunto ao dos $\operatorname{acionistas}^{121}$.

O intuito, portanto, não seria apenas proteger a companhia e seus acionistas de eventuais ofertas meramente oportunistas. Ao garantir este poder de intervenção aos administradores, estar-se-á a garantir maior estabilidade aos quadros da administração, permitindo e estimulando a adoção de projetos de longo prazo. Contudo, tal opção tornaria mais propensa a existência de atuações pela administração com vistas aos seus próprios interesses, que não necessariamente coincidiriam com o interesse social.

Adotam esta segunda forma, os sistemas jurídicos dos países que entendem que o conselho de administração, em razão da posição que ocupa, teria o dever de proteger a companhia e seus acionistas de ofertas prejudiciais ao interesse social, devendo sua atuação ser permitida e analisada ex post.

Dessa maneira, não se estaria a obstar por completo o conflito de interesses, mas sim a sujeitar eventual imputação de responsabilidade ao administrador que comprovadamente não atuou no interesse social.

Diante dessas duas possibilidades genericamente delineadas acima, optaram diversos países por uma ou outra, sendo os dois paradigmas mais relevantes os oriundos da Europa, em especial do Reino Unido, e dos Estados Unidos. Dessa forma, passaremos a analisar como a atuação do administrador e análise dessas condutas se dá em cada um desses sistemas jurídicos.

${ }^{121}$ OIOLI, Erik Frederico. Oferta pública de aquisição do controle de companhias abertas. São Paulo: Quartier Latin, 2010. p. 108. 


\subsubsection{União Europeia:}

\subsubsection{A Diretiva 2004/25/CE ("Diretiva")}

\section{A Diretiva foi promulgada pelo Parlamento Europeu e pelo Conselho} da UE, e estabelece medidas de coordenação entre as normas dos sistemas jurídicos dos países-membros da UE que se refiram às ofertas públicas para aquisição de valores mobiliários.

No que toca o objeto do presente estudo, destaca-se que um dos princípios da Diretiva é o de que o "órgão de administração da sociedade visada deve agir tendo em conta os interesses da sociedade no seu conjunto e não pode impedir os titulares de valores mobiliários de decidirem sobre o mérito da oferta" ${ }^{, 122}$.

Assim, a Diretiva, visando à neutralidade da administração em relação à oferta, estabeleceu que a decisão final acerca do êxito desta pertence exclusivamente aos acionistas. Trata-se da Board Neutrality Rule, positivada no art. $9^{\circ}(2)$ da Diretiva que dispõe que:

122 “Artigo $3^{\circ}$. Princípios gerais. 1. Para efeitos de aplicação da presente directiva, os EstadosMembros asseguram que sejam respeitados os seguintes princípios: a) Todos os titulares de valores mobiliários de uma sociedade visada de uma mesma categoria devem beneficiar de um tratamento equivalente; além disso, nos casos em que uma pessoa adquira o controlo de uma sociedade, os restantes titulares de valores mobiliários terão de ser protegidos; b) Os titulares de valores mobiliários da sociedade visada devem dispor de tempo e informações suficientes para poderem tomar uma decisão sobre a oferta com pleno conhecimento de causa; sempre que aconselha os titulares de valores mobiliários, o órgão de administração da sociedade visada deve apresentar o seu parecer no que diz respeito às repercussões da concretização da oferta sobre o emprego, as condições de emprego e os locais em que a sociedade exerce a sua actividade; c) $\mathrm{O}$ órgão de administração da sociedade visada deve agir tendo em conta os interesses da sociedade no seu conjunto e não pode impedir os titulares de valores mobiliários de decidirem sobre o mérito da oferta; d) Não devem ser criados mercados artificiais para os valores mobiliários da sociedade visada, da sociedade oferente ou de qualquer outra sociedade interessada na oferta de que resulte uma subida ou descida artificial dos preços dos valores mobiliários e que falseiem o funcionamento normal dos mercados; e) Um oferente só deve anunciar uma oferta depois de se assegurar de que está em plenas condições de satisfazer integralmente qualquer contrapartida em numerário, caso a oferta tenha sido feita nesses termos, e depois de tomar todas as medidas razoáveis para garantir a entrega de qualquer outro tipo de contrapartida; f) A sociedade visada não deve, em virtude de uma oferta respeitante aos seus valores mobiliários, ser perturbada no exercício da sua actividade para além de um período razoável. 2. Para efeitos da observância dos princípios previstos no n.o 1, os Estados-Membros: a) Asseguram que sejam satisfeitos os requisitos mínimos previstos na presente directiva; b) Podem estabelecer condições adicionais e disposições mais restritivas do que as exigidas pela presente directiva para regulamentar as ofertas." 
"o órgão de administração da sociedade visada é obrigado a obter a autorização prévia da assembleia-geral de accionistas para o efeito antes de empreender qualquer acção susceptível de conduzir à frustração da oferta, exceptuando a procura de outras ofertas e, nomeadamente, antes de proceder a qualquer emissão de valores mobiliários susceptível de impedir de forma duradoura que o oferente assuma o controlo da sociedade visada".

Conforme veremos, no que toca a matéria do presente estudo, esta é a principal distinção em relação ao que se dá no ordenamento jurídico dos EUA, no qual a verificação do conflito ocorre ex post, através de uma análise à luz de standards comportamentais. Diferentemente, o dispositivo acima não dá margem à ocorrência do potencial conflito de interesses subjacente às ofertas hostis, pois retira do conselho de administração, em caráter absoluto, a possibilidade de tomar qualquer decisão acerca de uma oferta pública, seja ela amigável ou hostil, sem que haja a prévia e expressa anuência dos acionistas ${ }^{123}$.

Ocorreu, entretanto, que o art. 12(1) da Diretiva permitiu que os Estados-membros não adotassem a norma contida no art. $9^{\circ}$ (2), autorizando, por conseguinte, que as legislações internas permitissem que os administradores adotem medidas defensivas, mesmo que não ad referendum da assembleia geral.

Assim, alguns países, como, por exemplo, Inglaterra, Espanha, França, Portugal e Itália, adotaram a vedação do Artigo $9^{\circ}$ (2) da Diretiva, enquanto outros, como é o caso da Alemanha, Bélgica, Grécia, Holanda, Hungria, Luxemburgo e Polônia, não o fizeram ${ }^{124}$.

Sem prejuízo da autorização supramencionada, a Diretiva obriga irrestritamente que a administração da companhia-alvo (de qualquer paísmembro) elabore e publique um parecer fundamentado acerca da conveniência da oferta, elucidando quais seriam, no seu ponto de vista, as

\footnotetext{
${ }^{123}$ A única exceção a tal regra está na possibilidade de se buscar um white knight, tema que trataremos adiante.

${ }^{124}$ NASCIMENTO, João Pedro Barroso do. Medidas Defensivas à Tomada de Controle de Companhias. São Paulo: Quartier Latin, 2011. p. 245.
} 
repercussões que o sucesso da oferta geraria ao interesse social e opinando sobre os planos estratégicos do ofertante para a companhia ${ }^{125}$.

Dentre os diversos países que são submetidos à Diretiva, a Inglaterra é aquele cujos delineamentos do sistema jurídico que mais contribuem à análise do objeto estudo. Assim, passaremos à análise do sistema jurídico britânico.

\subsubsection{Reino Unido}

Em matéria de regulação de ofertas hostis, caracteriza-se o sistema britânico pela sua forte autorregulação. Dentre as diversas normas autorreguladoras, destaca-se o City Code on Take-overs and Mergers ("City Code"), um conjunto de normas que foi elaborado pelos principais players de Londres, cuja autoridade competente para exigir o cumprimento de suas regras é o Takeover Panel.

Em relação à atuação dos administradores em ofertas hostis, o City Code proíbe os administradores de adotarem medidas defensivas que possam gerar o insucesso de ofertas de boa-fé sem que haja aprovação assemblear $^{126}$ e 127 . Assim, um dos princípios basilares do City Code é de que a decisão a respeito da oferta deve ser da competência exclusiva dos acionistas, não podendo os administradores nela intervir ${ }^{128}$. Trata-se do que se chama de "Non-Frustration Rule", positivada na Regra 21 do City Code $^{129}$.

\footnotetext{
${ }^{125}$ Nessa seara, demonstraremos à frente por que entendemos que tal regra se coaduna ao espírito da LSA, devendo, consequentemente, ser observada pelo conselho de administração das companhias brasileiras.

${ }^{126}$ FERREL, Allen. Why Continental European Takeover Law Matters. Harvard John M. Ollin Center for Law, Economics and Business Discussion Paper, n. ${ }^{\circ}$ 454, p. 11, 2003.

${ }^{127}$ A exceção também se refere ao white knight.

${ }^{128}$ DAVIES, Paul L. Shareholder Value: Company Law and Securities Markets Law - A British View. Out. 2000.

129 '21.1 WHEN SHAREHOLDERS' CONSENT IS REQUIRED (a) During the course of an offer, or even before the date of the offer if the board of the offeree company has reason to believe that a bona fide offer might be imminent, the board must not, without the approval of the shareholders in general meeting, take any action which may result in any offer or bona fide possible offer being frustrated or in shareholders being denied the opportunity to decide on its
} 
Assim, na ocorrência ou iminência de uma oferta hostil, não havendo prévia autorização assemblear, veda-se à administração: (a) tomar qualquer medida que possa frustrar a oferta ou negar aos acionistas a decisão acerca do seu mérito; ou (b) (i) emitir ações ou transferi-las ou resgatar ou recomprar as ações da companhia em nome da própria; (ii) emitir opções relativas a ações que até então não tenham sido emitidas; (iii) criar ou emitir quaisquer valores mobiliários conversíveis em ações ${ }^{130}$; (iv) dispor ou adquirir quaisquer ativos de valor relevante; ou (v) celebrar contratos fora do curso normal dos negócios.

merits, or: (i) issue any shares or transfer or sell, or agree to transfer or sell, any shares out of treasury or effect any redemption or purchase by the company of its own shares; (ii) issue or grant options in respect of any unissued shares; (iii) create or issue, or permit the creation or issue of, any securities carrying rights of conversion into or subscription for shares; (iv) sell, dispose of or acquire, or agree to sell, dispose of or acquire, assets of a material amount; or (v) enter into contracts otherwise than in the ordinary course of business. (b) The Panel must be consulted in advance if there is any doubt as to whether any proposed action may fall within Rule 21.1(a). (c) The Panel will normally agree to disapply Rule 21.1(a) if: (i) the taking of the proposed action is conditional on the offer being withdrawn or lapsing (see also Rule 21.1(e)); (ii) the offeror consents to the action proposed to be taken by the board of the offeree company; (iii) holders of shares carrying more than $50 \%$ of the voting rights of the offeree company state in writing that they approve the proposed action and would vote in favour of any resolution to that effect proposed at a general meeting; (iv) the proposed action is in pursuance of a contract entered into before the beginning of the period referred to in Rule 21.1(a) or another pre-existing obligation; or (v) a decision to take the proposed action had been taken before the beginning of the period referred to in Rule 21.1(a) which: (A) has been partly or fully implemented before the beginning of that period; or (B) has not been partly or fully implemented before the beginning of that period but is in the ordinary course of business. (d) Where shareholder approval is to be sought in general meeting for a proposed action in accordance with Rule 21.1(a): (i) the board of the offeree company must obtain competent independent advice as to whether the financial terms of the proposed action are fair and reasonable; (ii) the Panel must be consulted regarding the date of the general meeting; and (iii) the board of the offeree company must send a circular to shareholders containing the details set out in Note 1 as soon as practicable after the announcement of the proposed action. (e) Where the Panel has agreed to disapply Rule 21.1(a) because the proposed action is conditional on the offer being withdrawn or lapsing, the board of the offeree company must publish an announcement containing the details set out in Note 1. (See also Rule 30.1(c), pursuant to which the Panel may require a copy of the announcement (or a document which includes the contents of the announcement) to be sent to the persons referred to in that Rule.)".

${ }^{130}$ Em relação a tais hipóteses, percebe-se a preocupação do sistema britânico de evitar que o conselho de administração faça uso do capital autorizado para emitir valores mobiliários de forma a obstar ou dificultar a oferta hostil. No caso brasileiro, o conselho de administração está autorizado a emitir ações, opções, bônus de subscrição e debêntures, dentro do capital autorizado (arts. 59, 75 e 168 da LSA). Apesar disso, a emissão de tais valores mobiliários deverá se dar sem acarretar em diluição injustificada (art. 170, caput, LSA), devendo ser adotado como critérios para fixação do preço de emissão a perspectiva de rentabilidade da companhia, o valor do patrimônio líquido da ação ou a cotação de suas ações em Bolsa de Valores ou no mercado de balcão organizado, admitido ágio ou deságio em função das condições do mercado. Assim, diversamente do que ocorre nas poison pills dos EUA, a emissão de tais valores mobiliários não gera um desequilíbrio econômico, o que faz com que seus efeitos sejam muito mais brandos. 
Considerando que tal redução na atuação da administração pode resultar em estímulo a ofertas oportunistas, o City Code traz uma série de regras que visam proteger os acionistas da companhia-alvo, como, por exemplo, um extenso fornecimento de informações a respeito do ofertante e a vedação à imposição de condições potestativas à oferta ${ }^{131},{ }^{132}$.

\subsubsection{Estados Unidos}

Conforme mostramos no item acima, o direito britânico aloca a decisão acerca da conveniência da oferta inteiramente nas mãos dos acionistas, de forma a exaurir a possibilidade de um eventual conflito de interesses. O mesmo não ocorre nos Estados Unidos. Neste sistema jurídico, entende-se que o conselho de administração deve proteger sua companhia contra tomadas hostis que representem ameaças, tendo, portanto, uma função de proteção (gatekeeping function), não podendo se manter inerte e passivo em tal conjuntura. Há, portanto, uma maior preocupação em permitir que o conselho de administração proteja os acionistas do que com o potencial conflito de interesses que tais operações ocasionam.

O direito societário norte-americano, como veremos, é rico em matéria de tomadas hostis graças à alta ocorrência destas na prática jurídica. Assim, por permitir a atuação dos administradores, fazendo com que esta fosse analisada ex post, diversos casos foram levados aos tribunais dos mais diversos estados norte-americanos, sendo, entretanto, em Delaware que se desenvolveram os mais significativos conceitos.

A fim de delinear tais conceitos, passaremos a analisar dois dos casos mais paradigmáticos para aferir o que deles se pode extrair e que contribuirão para a análise do objeto do presente trabalho à luz do ordenamento jurídico brasileiro.

\footnotetext{
${ }^{131}$ Regras 31.1

132 Nosso ordenamento jurídico também veda a imposição de condições puramente potestativas por força da parte final do caput do art. 122 do CC.
} 


\subsection{Unocal Corp. v. Mesa Petroleum Co.}

No caso Unocal ${ }^{133}$, a conduta dos membros do conselho de administração da Unocal Corp. ("Unocal") na defesa de uma tender offer realizada pela Mesa Petroleum Co. ("Mesa") foi objeto de análise pela Suprema Corte de Delaware. Passaremos a um breve relato dos fatos que originaram a disputa.

Na década de 1980, a Unocal estava passando por dificuldades, pois não vinha obtendo êxito na sua principal atividade, qual seja, perfuração de poços de petróleo no Estado do Alasca. Observando que a Unocal tinha um forte potencial e que estava operando em baixa, Thomas Boone Pickens Jr., por meio da Mesa, decidiu tomar o controle da Unocal.

À época dos acontecimentos, a Mesa detinha cerca de $13 \%$ do capital da Unocal e, a fim de obter o controle desta, realizou uma oferta pública para adquirir aproximadamente $37 \%$ do capital social pagando US\$54,00 por ação. A oferta previa ainda que, posteriormente as ações remanescentes seriam objeto de permuta pela Mesa. O pagamento de tais ações se daria com títulos de dívida que foram inicialmente avaliados em US\$54,00 pela Mesa.

Preocupados, os administradores da Unocal realizaram diversos estudos que não só concluíram que o valor das ações da companhia seria significativamente superior aos US\$54,00 oferecidos pela Mesa, como também que os títulos de dívida a serem permutados eram "junk bonds", tendo valor individual muito inferior aos US\$54,00 inicialmente apresentados. Desse modo, os administradores compreenderam o forte caráter coercitivo da oferta da Mesa e a rejeitaram.

${ }^{133}$ Unocal v. Mesa Petroleum (493 A.2d 946, Delaware, 1985, Rel. Andrew G. T. Moore). 
Em sequência, os administradores da Unocal, em nome desta, realizaram uma oferta pública para recomprar $29 \%$ do capital da Unocal, excetuando-se, entretanto, quaisquer ações detidas pela Mesa. Em tal oferta, o conselho de administração estabeleceu que pagaria US\$72,00 por ação por meio de títulos de dívidas, aumentando, consequentemente, o endividamento da Unocal.

Inconformada com a atuação do conselho de administração da Unocal que não deu tratamento equânime aos acionistas e obstou a sua oferta formulada, a Mesa ajuizou uma ação em face destes perante a Suprema Corte de Delaware.

Os julgadores, por sua vez, determinaram que os membros do conselho de administração da Unocal não teriam violado seus deveres fiduciários, pois à época dos fatos, permitia-se que uma companhia negociasse suas próprias ações ${ }^{134}$, podendo seus administradores, inclusive, em certos casos, fazê-lo de forma seletiva, desde que tal não decorra do interesse, próprio ou exclusivo, de entrincheirarem-se em seus cargos na administração, conforme já havia sido determinado no caso Cheff v. Mathes ${ }^{135}$. Assim afirmou o juiz Andrew G. T. Moore:

"the powers here being exercised derive from 8 Del. C. $\S 160$ (a), conferring broad authority upon a corporation to deal in its own stock. From this it is now well established that in the acquisition of its shares a Delaware corporation may deal selectively with its stockholders, provided the directors have not acted out of a sole or primary purpose to entrench themselves in office" ${ }^{\text {136. }}$.

Assim, na análise da conduta dos administradores, o tribunal entendeu que, tendo em vista que a administração da companhia tem o poder de geri-la, o que inclui a possibilidade de tomar medidas defensivas, e que a business judgment rule se aplica aos atos negociais dos administradores, tal standard comportamental também deveria ser aplicado à adoção de defesas a ofertas hostis.

\footnotetext{
1348 Del. C. $\$ 160$ (a).

${ }^{135}$ Cheff v. Mathes (199 A.2d 548, Delaware, 1964, Rel. James B. Carey).

${ }^{136}$ Unocal v. Mesa Petroleum (493 A.2d 946, Delaware, 1985, Rel. Andrew G. T. Moore).
} 
Contudo, em razão do potencial conflito de interesses, para que a business judgment rule fosse aplicada nesse cenário, caberia ao conselho de administração o ônus de provar, conforme mencionado acima, que agiu no melhor interesse da companhia ${ }^{137}$. Para tanto, a conduta dos administradores deveria passar no que se denominou "Unocal Test".

Em primeiro lugar, haveria a threat analysis, na qual a administração teria que apontar os indícios que a fizeram acreditar que a alteração do poder de controle representaria, naquela conjuntura, uma ameaça ao interesse social. Para tanto poderiam ser apontados alguns fatores como: (i) valores ofertados inadequados; (ii) pagamento das ações por meio de permuta cujos títulos a serem permutados teriam qualidade duvidosa; (iii) prazo de oferta inadequado; (iv) prováveis impactos negativos ao stakeholders que poderiam ser gerados pelo êxito da oferta; e (vii) risco de os acionistas equivocadamente aceitarem a oferta por estarem mal informados ${ }^{138}$.

Evidenciando com sucesso os motivos que levaram o conselho de administração a entender que havia uma ameaça, dar-se-ia, em sequência, a reasonability analysis, por meio da qual a administração deveria comprovar que a medida adotada foi proporcional à ameaça sofrida. A análise da proporcionalidade da medida adotada se daria sob dois aspectos, quais sejam, o da coercitividade e o da preclusividade ${ }^{139}$. O primeiro se refere a uma medida defensiva adotada pela administração que impõe aos acionistas uma transação alternativa à oferta hostil, independentemente da sua vontade $^{140}$. Por outro lado, a medida preclusiva seria aquela que blinda a

\footnotetext{
137 SCALZILLI, João Pedro. Mercado de Capitais, Ofertas Hostis e Técnicas de Defesa. São Paulo: Quartier Latin, 2015. p. 171

138 CLARK, Robert. Corporation law. Boston: Little Brown and Company, 1986. p. 587; EISENBERG, Melvin A. Corporations and other business organizations. New York: Foundation Press, 2000. p. 856; O'KELLEY, Charles R. T.; THOMPSON, Robert B. Corporations and other business associations. $5^{\mathrm{a}}$ ed. New York: Aspen Publishers, 2006. p. 801.

139 Tal análise não foi feita no caso Unocal, mas foi aderida ao Unocal Test por meio do caso Unitrin (Unitrin, Inc. v. American General Corp. (1995).

${ }^{140}$ SCALZILLI, João Pedro. Mercado de Capitais, Ofertas Hostis e Técnicas de Defesa. São Paulo: Quartier Latin, 2015. p. 181.
} 
companhia por completo, obstando que aos seus acionistas possa ser formulada qualquer oferta, positiva ou não ${ }^{141}$.

Sendo a medida adotada pelo conselho de administração coercitiva e/ou preclusiva, esta não passará pelo escrutínio do Unocal Test levando, consequentemente, à análise do mérito da decisão tomada. Entretanto, não sendo o caso, aplicar-se-á a business judgment rule, gerando a já mencionada inversão do ônus da prova.

Dessa forma, do julgamento deste caso, nasceram os "Deveres Unocal" que determinam que, quando diante de uma tentativa de tomada hostil de controle, devem os administradores averiguar, por meio de investigação razoável, se se trata ou não de uma ameaça e, em caso positivo, adotar medidas defensivas razoáveis e proporcionais à ameaça sofrida, desde que estas não sejam preclusivas ou coercitivas.

Agindo consoante os Deveres Unocal, por se entender que a intervenção do conselho de administração em uma tentativa de tomada de controle é uma decisão de caráter negocial, aplica-se a business judgment rule, gerando a inversão do ônus da prova, fazendo com que aquele que se contrapõe aos atos do conselho de administração tenha a obrigação de provar que tais atos se deram de má-fé.

Conforme trataremos adiante, entendemos que os Deveres Unocal, com as devidas adaptações, podem ser uma interessante fonte para a análise da conduta dos administradores no nosso ordenamento, visto a escassez de normas que regulam seu papel nas tomadas hostis.

\subsection{Revlon v. MacAndrews and Forbes Holdings, Inc.}

No caso Revlon ${ }^{142}$, a companhia Revlon possuía medidas defensivas preventivas ${ }^{143}$ que incluíam a participação de seu conselho de administração

\footnotetext{
${ }^{141}$ SCALZILLI, João Pedro. Ibid., p. 181.

${ }_{142}$ Revlon v. MacAndrews and Forbes Holdings, Inc. (506. A.2d 173, Delaware, 1986, Rel. Andrew G.T. Moore).
} 
nas negociações que envolvessem a tomada do controle acionário da companhia.

Em 1986, os membros do conselho de administração da Revlon rejeitaram uma oferta formulada pelo grupo Pantry Pride que ofereceu US $\$ 45,00$ por ação, pois a considerou baixa. Insatisfeito, Pantry Pride demonstrou estar disposto a realizar novas investidas, o que fez com que Revlon acionasse um plano de poison pill e um programa de recompra de suas ações. Ao mesmo tempo, os administradores procuraram um white knight e contataram Forstmann Little para realizar uma oferta pública concorrente à formulada por Pantry Pride. Dessa forma, os dois concorrentes passaram a realizar diversas ofertas gerando um consequente aumento no valor de cotação das ações da Revlon.

Ao cabo, os administradores aceitaram uma oferta de Forstmann Little de US\$57,25 por ação, em detrimento de outra da Pantry Pride que ofereceu US\$56,25 por ação.

Ocorre, entretanto, que o conselho de administração ofereceu à Forstmann Little diversas vantagens, dentre elas uma opção de compra de duas estratégicas subsidiárias da Revlon por um preço abaixo do mercado que poderia ser exercida a hipótese de alguém adquirir $40 \%$ (quarenta por cento) ou mais do capital da companhia, além de exclusividade nas negociações para alteração do controle da Revlon, conjugada com uma break-up fee de cerca de US\$25.000.000,00 caso a Revlon desistisse do negócio.

Assim, quando o caso foi levado à Suprema Corte de Delaware, os julgadores concluíram que a conduta dos administradores não havia sido adequada. Entendeu-se que os administradores aceitaram a oferta mencionada para evitar prejuízos à Revlon oriundo das vantagens dadas ao Forstmann Little que desequilibraram a disputa pelo controle acionário da Revlon. Desse modo, a aceitação não só não decorreu do preço ofertado,

\footnotetext{
${ }^{143}$ São preventivas as medidas que são adotadas previamente à oferta hostil. Tais visam tornar a companhia menos penetrável às novas maiorias de acionistas, mediante formulações internas.
} 
como também obstou a continuidade da disputa que poderia ter ensejado uma elevação ainda maior do valor de cotação das ações da Revlon.

Dessa forma, o caso em comento resultou na geração dos chamados "Deveres Revlon" que impõe aos administradores, quando no cenário de uma tentativa de tomada hostil de controle, cumprir seus deveres fiduciários de forma a maximizar o valor de venda da companhia ${ }^{144}$.

Por força dos Deveres Revlon, exige-se que: (i) os administradores da companhia busquem dar tratamento isonômico aos ofertantes, sejam estes hostis ou aliados da administração; (ii) a administração utilize medidas defensivas apenas excepcionalmente caso reconheça que a tomada do controle será benéfica ou inevitável; (iii) a administração busque sempre o melhor preço de venda, caso a aquisição do controle esteja em iminência; e (iv) a decisão final entre as ofertas pertença aos acionistas, sem prejuízo da administração atuar nas negociações a fim de buscar melhorar ao máximo possível os termos e condições para os acionistas.

Apenas a título de antecipação, assim como os Deveres Unocal, entendemos que os Deveres Revlon também podem ser adotados, em certa medida - enfatiza-se - no Brasil.

Analisados os dois modelos mais díspares de atuação dos administradores quando confrontados com uma tomada hostil, podemos concluir que, enquanto o sistema britânico obsta qualquer tipo de atitude por parte da administração a fim de evitar o sucesso de uma oferta hostil, o sistema norte-americano permite tal atuação, desde que dentro dos limites delineados acima.

Assim, cumpre agora analisar como isso se dá no nosso ordenamento jurídico.

\footnotetext{
144 "Board must perform its fiduciary duties in the service of a specific objective: maximizing the sale price of the enterprise" Revlon v. MacAndrews and Forbes Holdings, Inc. (506. A.2d 173, Delaware, 1986, Rel. Andrew G.T. Moore).
} 


\subsection{Brasil}

Como já adiantamos, o ordenamento jurídico brasileiro possui um verdadeiro vácuo legislativo quando se trata de regular a atuação dos administradores quando em face de uma tentativa de tomada hostil. Conforme afirma Nelson Eizirik, apesar:

"de a Lei das S.A. conter dispositivos disciplinando a OPA para aquisição de controle, não existem no ordenamento jurídico brasileiro regras claras estabelecendo deveres, responsabilidades e limites de atuação dos administradores diante dessas ofertas, notadamente no que se refere às táticas de defesa que eles podem utilizar contra elas" $"$.

Destacamos, desde logo, que é esse hiato legislativo que faz nosso sistema se diferenciar dos demais ordenamentos explicitados acima. Em outras palavras, diversamente do sistema britânico (nos quais há uma forte autorregulação) e do sistema norte-americano (onde a jurisprudência é encarregada de criar o direito - como o fez nessa seara), nosso sistema legislativo não positivou qualquer norma específica acerca do objeto do presente estudo.

Dessa forma, não há qualquer disposição expressa em lei que autorize, permita ou vede a priori a administração de intervir nas ofertas hostis para aquisição do poder de controle. Assim, para aferir a existência de tal dever, poder ou proibição importa analisar as disposições dos já delineados deveres fiduciários.

Como vimos, o administrador, por força do art. 154 da LSA, deve exercer suas atribuições, as quais são delegadas pela lei e pelo estatuto, na direção do interesse social, não podendo, em virtude do inciso II do art. 155 da LSA, "omitir-se no exercício ou proteção de direitos da companhia".

\footnotetext{
${ }^{145}$ EIZIRIK, Nelson; HENRIQUES, Marcus de Freitas; VIEIRA, Juliana Botini Hargreaves. $O$ cômite de aquisições e fusões: versão brasileira do takeover panel. In: KUYVEN, Luiz Fernando Martins (Coord.). Temas essenciais de direito empresarial. São Paulo: Saraiva, 2012. p. 892.
} 
Logo, o primeiro ponto a ser resolvido é se há direito da companhia a ser protegido em casos de ofertas hostis de forma a ensejar a atuação dos administradores por se tratar de dever imposto por lei. Nessa seara, acreditamos que é cabível a atuação, dentro dos limites que explicitaremos adiante, caso a oferta hostil "coloque em risco a preservação da organização produtiva" ${ }^{\text {"146 }}$. Concordamos nesse ponto com Erik Frederico Oioli:

"Nesse sentido, para proteção do interesse da companhia e do interesse público de preservação da empresa, o uso de técnicas de defesa deve ser legítimo." ${ }^{147}$

Entretanto, adianta-se, tal poder não pode ser exercido em termos irrestritos, nem mesmo na extensão que se permite no sistema norteamericano. Como veremos, se a legislação não é expressa ou clara nessa seara, fato o é que há algo cristalino nessa zona cinzenta: a decisão final sobre o sucesso ou insucesso de uma oferta (hostil ou amigável) pertence única e exclusivamente aos acionistas. Contudo, devemos analisar alguns aspectos que envolvem essa soberania quando se trata de uma oferta pública.

Em primeiro lugar, toda e qualquer OPA influi em uma pressão que pode obstar uma tomada de decisão consciente por parte dos acionistas, sem prejuízo de uma (provável) assimetria informacional.

Conforme vimos, os acionistas de companhias com capital disperso possuem um problema de ação coletiva. Assim:

“a chamada 'distorção da decisão' dos acionistas destinatários de uma OPA se dá por que eles são incapazes de se coordenar para recusar uma oferta que não consideram boa, e não necessariamente por um suposto mal infligido pelo ofertante. $\mathrm{O}$ acionista pode ter sua opinião intimamente formada sobre a oferta, mas ainda sim pode manifestá-la de forma diversa e consciente porque não consegue antever qual será a decisão dos demais acionistas. Tal comportamento tenderá a existir independentemente de qual seja o receio do acionista em recusar a oferta, bastando que haja um motivo para não aceitá-la"148.

146 COMPARATO, Fábio Konder; SALOMÃO FILHO, Calixto. O Poder de Controle na Sociedade Anônima (1976), 4ª ed. Rio de Janeiro: Forense, 2005. p. 263.

${ }^{147}$ OIOLI, Erik Frederico. Oferta pública de aquisição do controle de companhias abertas. São Paulo: Quartier Latin, 2010. p. 202.

${ }^{148}$ OIOLI, Erik Frederico, Ibid., p. 156. 
Levando em consideração o problema da ação coletiva e que, por força do art. 123, § único, alínea 'c' da $\operatorname{LSA}^{149}$, apenas os acionistas que detenham 5\% (cinco por cento) do capital social podem convocar assembleia gerais (e ainda assim, apenas 8 (oito) dias depois do não atendimento de tal solicitação por parte dos administradores), entendemos que o papel do conselho de administração passa a ganhar relevância. Assim, em vista da ausência de disposição expressa em lei, quando da ocorrência de uma oferta hostil, entendemos que os administradores devem convocar uma assembleia geral para que os acionistas reunidos possam deliberar acerca da conveniência da oferta formulada, de forma a reduzir a natural pressão que sobre eles recai em tais circunstâncias. Acreditamos que a interpretação sistemática e teleológica da LSA acarreta na caracterização de tal dever por força do art. 154 da LSA, tendo o conselho de administração, por conseguinte, não só o dever de munir seus acionistas com as informações necessárias para a análise da deliberação a ser tomada, como também o dever de propiciar um ambiente no qual os acionistas possam discutir e debater os melhores caminhos a serem tomados. A oferta hostil não nos parece merecer qualquer exceção a isso.

\begin{abstract}
Além disso, é curioso destacar que tal:
"eventual decisão dos acionistas de permitir a adoção de técnicas de defesas pelos administradores importa, na prática, pelo menos em um primeiro momento, em recusa da oferta. Como é sabida, a decisão dessa natureza somente pode ser tomada em assembleia, cuja deliberação vincula os demais acionistas, ainda que discordantes em relação à matéria deliberada ou ausentes da assembleia. Haveria então uma subversão do sistema de aceitação da OPA. Embora tenham natureza de ato coletivo, as deliberações em assembleia e as aceitações dos acionistas no processamento da OPA não se confundem, uma vez que a primeira é ato colegial e a segunda não o é. A maioria dos acionistas estaria, portanto, interferindo
\end{abstract}

149 “Art. 123. Compete ao conselho de administração, se houver, ou aos diretores, observado o disposto no estatuto, convocar a assembléia-geral.

Parágrafo único. A assembléia-geral pode também ser convocada:

a) pelo conselho fiscal, nos casos previstos no número $\mathrm{V}$, do artigo 163 ;

b) por qualquer acionista, quando os administradores retardarem, por mais de 60 (sessenta) dias, a convocação nos casos previstos em lei ou no estatuto;

c) por acionistas que representem cinco por cento, no mínimo, do capital social, quando os administradores não atenderem, no prazo de oito dias, a pedido de convocação que apresentarem, devidamente fundamentado, com indicação das matérias a serem tratadas;

d) por acionistas que representem cinco por cento, no mínimo, do capital votante, ou cinco por cento, no mínimo, dos acionistas sem direito a voto, quando os administradores não atenderem, no prazo de oito dias, a pedido de convocação de assembléia para instalação do conselho fiscal." 
indevidamente na decisão particular do acionista destinatário da oferta. Interferência dessa natureza somente caberia a quem a lei atribui o dever de defender os interesses da companhia" ${ }^{150}$.

Dentre aqueles que a lei atribui tais deveres, encontram-se o acionista controlador (art. 116 da LSA) e os administradores (arts. 154 e 155, II da LSA), e é justamente por serem incumbidos de tais deveres que a legislação impõe limites através de normas que coíbem o abuso do poder de controle e a atuação sob conflito de interesses e que estipulam os deveres fiduciários $^{151}$.

Feitas essas breves ponderações, analisaremos como a atuação dos administradores em uma oferta hostil se enquadra em relação aos outros dois sistemas jurídicos já delineados, tendo em vista o vácuo que nosso ordenamento jurídico apresenta nessa seara.

Como vimos, o direito societário britânico, prezando pela neutralidade da administração, impõe a este órgão social um dever de se abster de praticar qualquer ato que vise frustrar a oferta. Por sua vez, o direito norteamericano atribui ao conselho de administração a função de proteger a companhia, não se exigindo uma neutralidade, mas sim que sua atuação se dê de acordo com os deveres e padrões comportamentais oriundos dos leading cases.

A abstenção da administração gerada pela regra de neutralidade, imposta pelo direito britânico, tem seus pontos positivos e negativos. Em relação aos primeiros, podemos destacar que tal regra evita casos nos quais os administradores atuem visando frustrar a oferta com base nos seus

\footnotetext{
${ }^{150}$ OIOLI, Erik Frederico. Oferta pública de aquisição do controle de companhias abertas. São Paulo: Quartier Latin, 2010. p. 203

${ }^{151}$ Em relação ao exercício do direito de voto pelos acionistas, controladores minoritários ou não, não podemos negar que na prática tal direito seja exercido unicamente por interesses pessoais (geralmente pelo preço ofertado), sem que o acionista considere o futuro daquela companhia após o sucesso da oferta. Por mais questionável que seja a questão à luz das disposições da LSA que, como vimos, apresenta, ao menos em tese, um caráter institucionalista, acreditamos ser difícil, salvo em caso de benefício particular em razão da operação em si, que a aceitação de uma oferta hostil por parte de acionistas possa ensejar qualquer tipo de responsabilidade. Como se sabe, uma das características das ações é sua circulabilidade. Assim, torna-se difícil pensar em qualquer tipo de responsabilização daquele que aceite alienar suas ações, mesmo que tal transação não se dê no sentido do capital social. Nessa seara, cumpre ainda relembrar a cláusula pétrea contida no art. $5^{\circ}$, $\mathrm{XX}$ da Constituição Federal, que determina que "ninguém poderá ser compelido a associar-se ou a permanecer associado".
} 
interesses meramente pessoais. É também possível afirmar que "a adoção de medidas defensivas pode limitar a criação de riquezas em eventuais disputas pelo controle societário, uma vez que, na existência de proteções, a tendência é que apenas as ofertas públicas amigáveis sejam levadas adiante, 152 .

Em polo oposto, podemos enumerar algumas vantagens no envolvimento da administração em tais ofertas. Inicialmente, visto a dispersão acionária característica das companhias objeto de tomadas hostis, percebe-se que os acionistas, de modo geral, não possuem informações suficientes para avaliar a adequação do preço ofertado, algo que a administração está em melhores condições para julgar em razão da posição que ocupa. Há, ainda, o já mencionado problema da ação coletiva dos acionistas, que torna complicada a possibilidade de negociação de melhores termos para a aquisição. Sob tais aspectos, a intervenção da administração seria benéfica.

Em razão dos deveres fiduciários estabelecidos nos arts. 154 e 155 da LSA, acreditamos, com as fortíssimas ressalvas que serão abordadas adiante, que o "papel dos administradores das companhias brasileiras se aproxima, portanto, do papel dos administradores no direito norteamericano, em contraste à regra de neutralidade emcampada por vários países da Europa" ${ }^{\prime 153}$, dentre eles a Inglaterra.

Conforme leciona João Pedro Barroso do Nascimento:

"as regras de neutralidade da administração, que surgem a fim de reduzir os problemas de agência entre acionistas e administradores, não devem ser entendidas como solução dos problemas no exercício da função dos administradores em operações de tomadas de controle. Conforme exposto, há importantes elementos positivos em tal envolvimento, que não podem ser descartados. Além disso, a regra de neutralidade da administração assume a premissa de que a atuação dos administradores de companhias em tentativas de controle será tendente a auferir benefícios. Há, aqui, nítida presunção de má-fé na atuação dos administradores, quando na verdade deveria haver presunção de boa-fé, na certeza de que as

\footnotetext{
152 NASCIMENTO, João Pedro Barroso do. Medidas Defensivas à Tomada de Controle de Companhias. São Paulo: Quartier Latin, 2011. p. 218.

${ }^{153}$ OIOLI, Erik Frederico. Oferta pública de aquisição do controle de companhias abertas. São Paulo: Quartier Latin, 2010. p. 204.
} 
disfunções no exercício de cargos na administração devem ser tratadas com o rigor da lei, aplicando-se-lhes todas as sanções possíveis" ${ }^{\text {"154 }}$.

Todavia, não podemos de forma alguma afirmar que devemos importar os conceitos e institutos oriundos do sistema norte-americano em sua integralidade. Tratam-se de sistemas muito distintos, especialmente quando se trata do papel do conselho de administração na estrutura societária da companhia. Nos EUA, a legislação de Delaware, por exemplo, determina que os membros do conselho de administração só poderão ser destituídos com justa causa, salvo se disposto em contrário nos atos constitutivos da companhia ${ }^{155}$. Quando contraposto com o arts. 122, II $^{156} \mathrm{e}$ $140^{157}$ da LSA, podemos ilustrar bem tal diferença. Diversamente da norma de Delaware, no Brasil, a assembleia geral é o órgão soberano, capaz de eleger e destituir os membros do conselho de administração a qualquer tempo, sem a necessidade de fundamentação. Assim, no Brasil, as competências do conselho de administração, quando comparadas com o que se dá nos Estados Unidos, são muito mais restritas, ainda mais quando se trata de imposição de medidas defensivas, pois geralmente exigirão aprovação assemblear.

Entretanto, por mais que grande parte das espécies de medidas defensivas não sejam aplicáveis, não significa dizer que o administrador não possa agir. Não entendemos que nossa legislação exclua a função dos administradores de proteger a companhia, mas sim que estes atuem em conjunto com os acionistas, a quem caberá a decisão final. Assim, entendemos que conselho poderá agir, mas não ilimitadamente. Como

\footnotetext{
${ }^{154}$ NASCIMENTO, João Pedro Barroso do. Op. cit., p. 219.

${ }^{155}$ Delaware General Corporation Law $\S 141$. (k)

${ }^{156}$ Art. 122. Compete privativamente à assembleia geral:

(...)

eleger ou destituir, a qualquer tempo, os administradores e fiscais da companhia, ressalvado o disposto no inciso II do art. 142;

157 "O conselho de administração será composto por, no mínimo, 3 (três) membros, eleitos pela assembléia-geral e por ela destituíveis a qualquer tempo..."
} 
veremos, "a utilização de mecanismos de defesa pelos administradores não deve ser indiscriminada, sujeitando-se a limites" $"$.

O primeiro limite a tal atuação dos administradores decorre da necessidade de observância dos ditames estabelecidos pelos deveres fiduciários, em especial os já explicitados deveres de diligência e lealdade.

Em relação ao dever de diligência, o ordenamento jurídico dos EUA preceitua que o administrador deve sempre agir de maneira informada e somente após ter ponderado todos os aspectos relevantes da oferta e da deliberação a ser tomada ${ }^{159}$. Caso o ato realizado não tenha sido precedido por tais requisitos, não poderá o administrador gozar da business judgment rule. Acreditamos que tal limite também se enquadre ao nosso ordenamento jurídico. Dessa forma, quando em face de uma tentativa de tomada hostil de controle, os administradores das companhias brasileiras deverão manter uma atuação proba e diligente, de boa-fé e de acordo o interesse social. Ademais, tal atuação também só poderá se dar após terem reunido todas as informações pertinentes e realizado uma análise razoável dos aspectos positivos e negativos que podem advir da oferta formulada.

Nessa seara, em vista do vácuo legislativo apresentado pelo nosso ordenamento jurídico, os Deveres Unocal nos parecem uma adequada fonte jurídica a ser utilizada. Assim, caberá aos administradores, ao menos em um primeiro momento, reunir as informações necessárias para aferir se de fato a OPA formulada representa ou não uma ameaça ao interesse social. Para tanto, a título meramente exemplificativo, dentre as diversas formas de obtenção de informações para formação da opinião da administração acerca da oferta hostil, poderão ser constituídos comitês independentes que analisarão os possíveis impactos da oferta aos diversos stakeholders e à própria companhia nos mais variados aspectos, bem como poderão ser

\footnotetext{
${ }^{158}$ OIOLI, Erik Frederico. Oferta pública de aquisição do controle de companhias abertas. São Paulo: Quartier Latin, 2010. p. 204.

${ }^{159}$ V. Smith v. Van Gorkom, 488 A.2d 858, 874 (Del. 1985).
} 
contratadas empresas especializadas para elaboração de pareceres independentes (fairness opinions).

Cumpre ressaltar, contudo, que tal análise da conveniência da oferta não pode se voltar única e exclusivamente para o seu fundamento econômico, isto é, para a adequação ou não do preço ofertado às ações da companhia. A análise deve ser feita à luz do art. 154 da LSA, levando em consideração, portanto, conforme mencionado, os possíveis impactos que poderão ser gerados não só aos acionistas, mas também ao interesse social, incluindo neste o interesse dos diversos stakeholders e a função social da empresa, sem prejuízo, por óbvio, da adequação do preço ofertado.

Dessa forma, com base na análise feita, poderão os administradores, caso visualizem uma ameaça na oferta, atuar de maneira proporcional, dentro dos limites legais, de forma a frustrá-la. Entretanto, como já adiantado, tal atuação será muito mais restrita do que a que ocorre nos EUA, em virtude da subordinação da validade de diversas medidas defensivas ao escrutínio da assembleia geral.

Por sua vez, o dever de lealdade também representa uma restrição à atuação dos administradores. Na verdade, é o próprio dever de lealdade que, ao nosso ver, simultaneamente exige e restringe a atuação dos administradores. Tal dever fiduciário aloca na figura do administrador o dever de proteção dos direitos da companhia (art. 155, II, LSA). Assim, ao mesmo tempo em que exige a atuação dos administradores quando da ocorrência de uma oferta hostil que na sua opinião baseada na análise feita de acordo com o dever de diligência nos moldes acima delineados, representa uma ameaça ao interesse social, o dever de lealdade também impõe que tal atuação só deva se dar caso a oferta de fato represente uma ameaça. Do contrário, não haverá direito a ser protegido, não podendo o 
conselho de administração, por conseguinte, atuar de forma a frustrar a oferta formulada ${ }^{160}$.

Em relação ao sistema norte-americano, concordamos com as palavras de João Barroso do Nascimento:

"O dever de lealdade corresponderia, entre nós, ao standard of loyalty compreendido no amplo dever fiduciário norte-americano. Sendo assim, mesmo que a experiência nacional ainda seja acanhada em operações de tomada de controle e, consequentemente, na utilização concreta de defesas, as reflexões sobre a observância ao standard of loyalty em situações de tomada de controle nos países da common law pode auxiliar na reflexão no Brasil sobre o amoldamento do dever de lealdade às situações desta natureza que ocorrerem em nosso país. Portanto, alguns casos concretos submetidos aos tribunais dos EUA, mas sob a roupagem do standard of loyalty, podem sugerir referências interpretativas no Brasil." 161

Quando se fala em ofertas hostis, os casos Unocal e Revlon surgem para tratar da questão.

Por força do julgmanento do caso Unocal, determinou-se que a business judgment rule será aplicada caso a administração da companhiaalvo, após realizar uma devida investigação, demonstrar que a oferta de fato representava uma ameaça à companhia e que a medida defensiva adotada foi razoável e proporcional a tal ameaça, não sendo preclusiva ou coercitiva, tendo sido realizada em prol do interesse dos acionistas ${ }^{162}$.

Por sua vez, em razão da decisão proferida no caso Revlon, existe no ordenamento norte-americano os Deveres Revlon que demandam da administração uma atuação no interesse dos acionistas, de forma a maximizar seus investimentos ao máximo possível.

Ocorre, entretanto, que tanto os Deveres Unocal quanto os Deveres Revlon não podem ser importados integralmente no ordenamento jurídico

\footnotetext{
${ }^{160}$ Entendemos, entretanto, que tal restrição não necessariamente obsta a convocação de uma assembleia geral. Como vimos, nas companhias em que não há controlador, é possível que nenhum acionista com mais de 5\% do capital social solicite a realização de uma assembleia para deliberar sobre a oferta formulada. Assim, não vemos prejuízo ao interesse social na convocação de uma assembleia para que se possa fornecer um canal de comunicação entre os diversos acionistas, de forma a propiciá-los um ambiente de debate que tenderá a elucidar diversos aspectos da oferta formulada e que poderá auxiliar na formação de vontade individual e coletiva acerca da aceitação ou não de tal oferta.

${ }^{161}$ NASCIMENTO, João Pedro Barroso do. Medidas Defensivas à Tomada de Controle de Companhias. São Paulo: Quartier Latin, 2011. p. 234.

${ }_{162}$ VELASCO, Julian. The Enduring Illegitimacy of the Poison Pill. In: The Journal of Corporation Law, vol. 27, $\mathrm{n}^{\circ} 3,2002$, p. 390.
} 
brasileiro. Tais deveres previstos no sistema dos EUA são voltados para os acionistas da companhia-alvo. Por outro lado, como se sabe, os deveres fiduciários impostos pela LSA deixam claro que os administradores têm deveres para com a companhia, e não para com os acionistas desta ${ }^{163}$. Em outras palavras, a atuação dos administradores não deve se dar necessariamente no interesse dos acionistas, mas sim na busca pela concretização do interesse social, que não coincidirá obrigatoriamente com o interesse dos acionistas.

É possível, como já afirmado, que o principal interesse do acionista seja a maximização do valor ofertado pelas suas ações, pouco lhe importando o futuro da companhia após a concretização da aquisição. “Assim, o futuro da companhia e sua capacidade de continuar expandindose e gerando lucros a serem distribuídos aos acionistas remanescentes da companhia, bem como futuros acionistas, pode ser relegado ao segundo plano pelos acionistas destinatários da oferta"164. Diversamente do que ocorre no plano dos acionistas, em especial nos casos em que não haja um controlador minoritário, a administração, por gerir patrimônio alheio, possui deveres fiduciários, o que lhe obrigará a atuar visando à concretização do interesse social, do bem público, e da função social da empresa, de forma a conservar tal unidade produtiva. Assim, em relação aos administradores, não se pode conceber que a maximização do valor de venda deva exclusivamente guiar sua atuação na defesa de tomadas hostis ${ }^{165}$. Dessa forma, a adoção dos conceitos oriundos do sistema norte-americano

\footnotetext{
${ }^{163} \mathrm{O}$ art. 154 da LSA deixa claro que o administrador deve buscar "lograr os fins e no interesse da companhia" e que o "administrador eleito por grupo ou classe de acionistas tem, para com a companhia, os mesmos deveres que os demais, não podendo, ainda que para defesa do interesse dos que o elegeram, faltar a esses deveres". A seu turno, o art. 155 da LSA determina que o administrador deve servir com lealdade à companhia.

${ }_{164}$ OIOLI, Erik Frederico. Oferta pública de aquisição do controle de companhias abertas. São Paulo: Quartier Latin, 2010. p. 208.

${ }^{165}$ Cumpre ressaltar que a busca pela maximização do valor ofertado não deve ser negligenciada pelos administradores. De fato, o valor a ser pago não entrará nos "cofres" da companhia, e sim no bolso dos acionistas que aceitarem a oferta. Entretanto, aos olhos do mercado, quanto maior o valor de venda, mais valorizada a companhia estará, o que, futuramente poderá vir a facilitar a sua continuidade. Isso será ainda mais relevante nas companhias que, tal qual aquelas listadas no segmento do Novo Mercado, possuírem apenas ações ordinárias, visto que a oferta se dará para a totalidade dos acionistas, não havendo qualquer diferenciação entre titulares de ações preferenciais e de ações ordinárias.
} 
depende da sua adequação aos preceitos da LSA, de modo que os deveres dos administradores sejam para a companhia, e não para seus acionistas. Logo, apesar de o preço ofertado estar adequado, pode ser que a concretização da oferta, por motivo diverso, represente uma ameaça ao interesse social, justificando sua defesa. $\mathrm{O}$ mesmo vale para a busca por um white knight, ou seja, apesar de entendermos que a administração deva procurar um concorrente para maximizar o valor de venda, não poderão os administradores buscarem um concorrente qualquer, com base exclusivamente em quanto tal concorrente está disposto a pagar, devendo, para tanto, fazer uma análise para averiguar a adequação da proposta deste, tal qual a que deveria ter sido feita para aferir a existência ou não de ameaça na oferta formulada pelo ofertante hostil. Em outras palavras, a proposta do ofertante concorrente também deve se moldar ao interesse social.

Por outro lado, não são apenas os acionistas que podem ter interesse diverso do interesse social. Os administradores, como já abordamos, podem adotar medidas defensivas apenas para se entrincheirar nos seus cargos, mesmo que em detrimento do interesse social. Logo, conforme adiantamos, a problemática está diretamente conecta ao conflito de interesses.

De acordo com o art. 156 da LSA, é vedado ao administrador intervir em operação social na qual tenha interesse conflitante com o da companhia. Para os defensores da teoria do conflito formal, já mencionada no presente trabalho, não poderiam os administradores realizar quaisquer atos que visassem frustrar a oferta ${ }^{166}$.

Por outro lado, aqueles que defendem a teoria do conflito substancial entendem que não se poderia interpretar o art. 156 da LSA de maneira conflitante com os seus arts. 154 e 155, II, que, respectivamente, exige a atuação de acordo com o interesse social e veda a omissão do administrador

\footnotetext{
${ }^{166}$ OLIVEIRA, Flávia Jardim de, e CARVALHO, Gabriela Cerqueira de. O Controle Gerencial e a Responsabilização do Administrador em Caso de Conflito de Interesses. São Paulo. Red GV. v. 01, n. 03, jul/2013, artigo 03, p. 53; FREITAS, Clarissa Figueiredo de Souza. Os poderes do conselho de administração para impor medidas defensivas contra ofertas hostis no direito comparado e na legislação brasileira. Revista de Direito Mercantil, Industrial, Econômico e Financeiro, São Paulo: Malheiros, v. 159/160, p. 127-141, jul./dez. 2011. p. 135.
} 
na defesa dos interesses da companhia ${ }^{167}$, autorizando, por conseguinte, a prática de tais atos cuja regularidade seria analisada ex post.

Acreditamos, entretanto, que a intervenção por parte dos administradores nas ofertas hostis não está abrangida pela norma contida no art. 156 da LSA:

"Isto porque a OPA não é uma operação social, haja vista que a companhia visada, embora tenha interesse na oferta, não é parte do negócio dela resultante. O negócio é celebrado entre acionistas e ofertante, e é nessa relação que o administrador irá interferir. Assim, ao agir ou se omitir na defesa de interesses pessoais em detrimento do interesse da companhia, haverá quebra dos deveres de lealdade e de agir de acordo com os fins da companhia e do seu interesse. Tratar-se-á, portanto, de violação aos artigos 154 e 155 da LSA, e não do artigo $156^{\prime \prime 168 . ~}$

Dessa forma, quando da adoção de medidas defensivas, os administradores e acionista controlador não podem fazê-las apenas para perpetuarem seus cargos ou seu poder de controle em detrimento da companhia. Conforme leciona Modesto Carvalhosa:

“o princípio fundamental é que os administradores e os controladores não podem utilizar-se da companhia visada, de seu patrimônio, de sua administração, de sua assembleia geral, e de seu estatuto para 'defender-se' da oferta. A utilização desses recursos inerentes à empresa constitui abuso de poder, como referido, de conotação gravíssima, devendo ser punido, outrossim, no plano da sua competência administrativa, pela Comissão de Valores Mobiliários"169.

Em face à ausência de normas expressas, a conduta dos administradores deve, portanto, ser analisada pelas disposições previstas na LSA relativas aos deveres fiduciários. Assim, a:

"atuação dos administradores destinada a 'entrincheirar-se' no cargo diante de uma tentativa de tomada de controle não sobreviveria ao exame pelas disposições do artigo 154 da Lei $\mathrm{n}^{\circ}$ 6.404/76. Da mesma forma, a atuação dos administradores como 'mandatários' identificados com os interesses dos acionistas que os elegeram, tanto na adoção da defesa quanto na omissão diante do ataque, seria veementemente rejeitada com base neste dispositivo"170.

Ademais, não se pode utilizar de medidas defensivas como uma "carta branca" para obstar uma oferta hostil. Tais medidas devem, portanto, estar

\footnotetext{
${ }^{167}$ SALOMÃO FILHO, Calixto; RICHTER JÚNIOR, Mário Stella. Interesse Social e Poderes dos Administradores na Alienação do Controle. In: RDM, n. ${ }^{\circ}$ 89, p. 73.

${ }_{168}$ OIOLI, Erik Frederico. Oferta pública de aquisição do controle de companhias abertas. São Paulo: Quartier Latin, 2010. p. 210.

${ }^{169}$ CARVALHOSA, Modesto. Comentários à Lei de Sociedades Anônimas, tomo II, vol. 4, $3^{\mathrm{a}}$ ed. São Paulo: Saraiva, 2002, p. 228.

${ }_{170}$ NASCIMENTO, João Pedro Barroso do. Medidas Defensivas à Tomada de Controle de Companhias. São Paulo: Quartier Latin, 2011. p. 232.
} 
em consonância com o interesse social. Cita-se, a título exemplificativo, a crown's jewel defense, medida defensiva por vezes utilizada no direito norte-americano, na qual a administração aliena ativos estratégicos da companhia a fim torná-la desinteressante aos olhos do ofertante. Em tais casos, a companhia restará prejudicada, e, por conseguinte, tal medida defensiva será ilegal. Não se pode, portanto, justificar um eventual prejuízo a ser gerado pelo ofertante em caso de sucesso da OPA, como argumento suficiente para danificar o patrimônio da companhia-alvo, de forma a tornála desinteressante ${ }^{171}$.

Outra limitação se encontra no princípio do tratamento isonômico dos acionistas de mesma classe, previsto no $\S 1^{\circ}$ do art. 109 da $\operatorname{LSA}^{172}$, e do direito de preferência (art. 171 da $\operatorname{LSA}^{173}$ ). Dessa forma, não pode a

\footnotetext{
${ }^{171}$ Em relação à atuação do ofertante, um exemplo semelhante seriam as Leveraged Buyouts, popularmente conhecidas como "LBO". Por meio de uma LBO, o ofertante financia o alto custo que decorre de qualquer tomada hostil para, após efetuada a aquisição, transferir as despesas que incorreu para a companhia adquirida. Assim, é como se a própria companhia financiasse a sua aquisição. Geralmente, o ofertante utiliza uma sociedade veículo para contrair o referido financiamento e fazer a oferta, para posteriormente incorporá-la à companhia que fora adquirida. Dessa maneira, por força da sucessão universal do patrimônio da incorporada, conforme prevista no art. 227 da LSA, a companhia assumirá, ao cabo, os custos da sua própria aquisição. Há ainda muitas vezes, a previsão no próprio contrato de financiamento que determinados bens ou ativos da companhia serão dados em garantia após a concretização da aquisição. Trata-se de clara violação ao art. $117, \S 1^{\circ}$, alínea 'b' da LSA e do art. 15, II da Instrução CVM n. ${ }^{\circ}$ 319/99, pois ao realizar uma incorporação para obter vantagens para si, em detrimento dos demais acionistas e da companhia, restará configurado o abuso do poder de controle.

172 "As ações de cada classe conferirão iguais direitos aos seus titulares".

${ }^{173}$ Art. 171. Na proporção do número de ações que possuírem, os acionistas terão preferência para a subscrição do aumento de capital.

$\S 1^{\circ}$ Se o capital for dividido em ações de diversas espécies ou classes e o aumento for feito por emissão de mais de uma espécie ou classe, observar-se-ão as seguintes normas:

a) no caso de aumento, na mesma proporção, do número de ações de todas as espécies e classes existentes, cada acionista exercerá o direito de preferência sobre ações idênticas às de que for possuidor;

b) se as ações emitidas forem de espécies e classes existentes, mas importarem alteração das respectivas proporções no capital social, a preferência será exercida sobre ações de espécies e classes idênticas às de que forem possuidores os acionistas, somente se estendendo às demais se aquelas forem insuficientes para lhes assegurar, no capital aumentado, a mesma proporção que tinham no capital antes do aumento;

c) se houver emissão de ações de espécie ou classe diversa das existentes, cada acionista exercerá a preferência, na proporção do número de ações que possuir, sobre ações de todas as espécies e classes do aumento.

$\S 2^{\circ}$ No aumento mediante capitalização de créditos ou subscrição em bens, será sempre assegurado aos acionistas o direito de preferência e, se for o caso, as importâncias por eles pagas serão entregues ao titular do crédito a ser capitalizado ou do bem a ser incorporado.

$\S 3^{\circ}$ Os acionistas terão direito de preferência para subscrição das emissões de debêntures conversíveis em ações, bônus de subscrição e partes beneficiárias conversíveis em ações emitidas
} 
administração, mesmo dentro do capital autorizado, emitir valores mobiliários e excluir o ofertante, caso acionista, da possibilidade de subscrevê-los.

Por fim, e mais importante, por força do inciso I do art. 122 da LSA, diversamente do ocorre no sistema norte-americano, não pode o conselho de administração, sem a prévia anuência dos acionistas, reunidos em assembleia geral, alterar o estatuto a fim de nele introduzir uma medida defensiva, como, por exemplo, uma cláusula de proteção à dispersão acionária $^{174}$ ou uma limitação ao número de $\operatorname{votos}^{175}$.

Assim, percebe-se que os poderes do conselho de administração para impor medidas defensivas são muito mais restritos no nosso sistema do que o que ocorre nos EUA. Entretanto, acreditamos que os administradores possam ter algumas possibilidades em mãos, ainda que não tão eficazes.

Em primeiro lugar, uma forma de atuação dos administradores seria a elaboração de um parecer fundamentado acerca da conveniência ou não da oferta. Em virtude da Instrução n. ${ }^{\circ}$ 487/10 da CVM, a autarquia:
"optou por deixar a critério do Conselho a decisão sobre se manifestar ou não sobre a oferta. Determinou, contudo, que, quando o Conselho decidir se manifestar, 'a manifestação deverá abordar todos os aspectos relevantes para a decisão do investidor, sobretudo o preço oferecido na OPA; a manifestação deve

\footnotetext{
para alienação onerosa; mas na conversão desses títulos em ações, ou na outorga e no exercício de opção de compra de ações, não haverá direito de preferência.

$\S 4^{\circ} \mathrm{O}$ estatuto ou a assembléia-geral fixará prazo de decadência, não inferior a 30 (trinta) dias, para o exercício do direito de preferência.

$\S 5^{\circ}$ No usufruto e no fideicomisso, o direito de preferência, quando não exercido pelo acionista até 10 (dez) dias antes do vencimento do prazo, poderá sê-lo pelo usufrutuário ou fideicomissário. $\S 6^{\circ} \mathrm{O}$ acionista poderá ceder seu direito de preferência.

$\S 7^{\circ} \mathrm{Na}$ companhia aberta, o órgão que deliberar sobre a emissão mediante subscrição particular deverá dispor sobre as sobras de valores mobiliários não subscritos, podendo:

a) mandar vendê-las em bolsa, em benefício da companhia; ou

b) rateá-las, na proporção dos valores subscritos, entre os acionistas que tiverem pedido, no boletim ou lista de subscrição, reserva de sobras; nesse caso, a condição constará dos boletins e listas de subscrição e o saldo não rateado será vendido em bolsa, nos termos da alínea anterior.

$\S 8^{\circ} \mathrm{Na}$ companhia fechada, será obrigatório o rateio previsto na alínea b do $\S 7^{\circ}$, podendo o saldo, se houver, ser subscrito por terceiros, de acordo com os critérios estabelecidos pela assembléiageral ou pelos órgãos da administração.

${ }^{174}$ A forma mais usual dessas cláusulas prevê, a grosso modo, que qualquer pessoa, que se torne titular de direitos de voto em quantidade igual ou superior a determinado percentual do capital votante, deverá realizar uma oferta pública para a aquisição de ações a fim de adquirir as demais ações de emissão de tal companhia.

${ }^{175}$ De acordo com o $\S 1^{\circ}$ do art. 110 da LSA, o "estatuto pode estabelecer limitação ao número de votos de cada acionista".
} 
descrever as alterações relevantes na situação financeira da companhia objeto ocorridas desde a data das últimas demonstrações financeiras ou informações trimestrais divulgadas ao mercado; e cópia da manifestação deverá ser divulgada ao mercado por meio de sistema eletrônico disponível na página da CVM na rede mundial de computadores" ${ }^{176}$.

Se, por um lado, a CVM optou por não exigir do conselho de administração a elaboração de um parecer fundamentado que pudesse suprir os acionistas de informações, de modo a possibilitá-los o exercício de uma decisão mais embasada, informada e consciente, a BM\&FBovespa, por sua vez, quando da alteração do regulamento do Novo Mercado, determinou que o:

"Conselho de Administração da Companhia deverá elaborar e tornar público parecer prévio fundamentado sobre toda e qualquer oferta pública de aquisição que tenha por objeto as ações de emissão da Companhia, no qual se manifestará: (1) sobre a conveniência e oportunidade da oferta quanto ao interesse do conjunto dos acionistas e em relação à liquidez dos valores mobiliários de sua titularidade; (2) sobre as repercussões da oferta sobre os interesses da Companhia; (3) quantos aos planos estratégicos divulgados pelo ofertante em relação à Companhia; e (4) outros pontos que considerar pertinente. No parecer, o Conselho de Administração deverá manifestar opinião fundamentada favorável ou contrária à aceitação da oferta pública de aquisição de ações, alertando que é de responsabilidade de cada acionista a decisão final acerca da aceitação ou não da referida oferta" ${ }^{177}$.

Consideramos que a inserção deste dispositivo no regulamento do Novo Mercado, segmento no qual a quase totalidade das companhias com alta dispersão acionária estarão, foi de grande valia, uma vez que tornou expressamente obrigatória ao conselho de administração de qualquer companhia listada nesse segmento que seja alvo de uma oferta pública, a elaboração de um parecer fundamentado, elencando ainda diversos aspectos que não poderão ser ignorados.

Em que pese tal avanço, a nosso ver, o relatório acima referido não só pode, como deve sempre ser elaborado pelo conselho de administração, esteja a companhia listada no Novo Mercado ou não. Em razão da posição que ocupa, não há ninguém que conheça melhor a companhia do que o

\footnotetext{
${ }^{176}$ SILVA, Carlos Alexandre Lobo e. A evolução da aquisição de controle de companhias abertas no Brasil. In: SILVA, Alexandre Couto [coordenador]. Direito societário. São Paulo: Saraiva, 2013. p. 248.

${ }^{177}$ SILVA, Carlos Alexandre Lobo e. A evolução da aquisição de controle de companhias abertas no Brasil. In: SILVA, Alexandre Couto [coordenador]. Direito societário. São Paulo: Saraiva, 2013. p. 248.
} 
conselho de administração, devendo, portanto, "necessariamente se manifestar em caso de uma oferta pública para aquisição de ações, como parte do seu dever fiduciário perante os acionistas" $" 178$. Cabe ao conselho de administração, portanto, reduzir a pressão gerada pela OPA, tendo tal órgão a capacidade de mitigar o problema da ação coletiva, através da convocação de assembleias gerais.

Além do parecer fundamentado, quando a ocorrência de uma tentativa de tomada hostil de controle, poderão os membros do conselho de administração realizar pedidos públicos de procuração ${ }^{179}$ a fim de alterar o estatuto social, de forma a incluir uma cláusula de proteção à dispersão acionária ou uma limitação ao número de votos de cada acionista. Dessa forma, acreditamos que, em relação às medidas defensivas que importem em alteração estatutária, não estão os administradores impedidos de convocar assembleias gerais, mesmo após o anúncio da oferta, para que os acionistas deliberem, pessoalmente ou por meio de procurador devidamente constituído, acerca da inclusão ou não de tal medida defensiva ${ }^{180}$.

Por fim, entendemos que a defesa do white knight (cavaleiro branco), na qual a administração procura um ofertante concorrente ao ofertante hostil, é plenamente cabível no ordenamento jurídico brasileiro, sendo inclusive regulada em parte pela figura da OPA concorrente, delineada acima. Tal medida é, inclusive, permitida pela Diretiva que, conforme vimos, privilegia neutralidade da administração. Acreditamos, entretanto, que na ausência de regulação acerca da possibilidade e/ou dever colocados expressamente em lei, no que tange ao cavaleiro branco, servem

\footnotetext{
${ }^{178}$ SILVA, Carlos Alexandre Lobo e. Ibid., p. 249

179 Art. $126, \S 2^{\circ}$ da LSA.

${ }^{180}$ Ressalta-se que não são possíveis as chamadas procurações em branco aceitas nos Estados Unidos, nas quais simplesmente se outorga apenas o exercício do direito de voto, sem indicação do sentido do voto a ser proferido. Entretanto, é possível solicitar uma procuração para que os acionistas outorguem o exercício do direito de voto para que este seja exercido no sentido indicado pela administração. Para tanto, é preciso que haja disposição expressa nesse sentido no instrumento de procuração outorgado. ROBERT, Bruno. Exercício do direito de voto nas assembleias das companhias brasileiras, pedidos públicos de procuração, voto e participação à distância. Tese de doutorado. Orientador: Eduardo Secchi Munhoz. Faculdade de Direito da Universidade de São Paulo: São Paulo, 2012. p. 332.
} 
os Deveres Revlon como adequada fonte interpretativa. Assim, entendemos que a administração deve buscar concorrentes ao ofertante hostil, estando obrigada a ainda a dar tratamento isonômico aos ofertantes e, quando permitida, atuar nas negociações a fim de buscar melhorar ao máximo possível os termos e condições da oferta, cuja aceitação ou recusa caberá, ao cabo, exclusivamente aos acionistas.

Assim, ao nosso ver, o conselho de administração deve "tentar promover um processo competitivo para tentar maximizar o valor a ser pago pelas ações" "181. Concordamos com João Pedro Barroso do Nascimento que defende que:

"A atuação do administrador em buscar outras opções de ofertas públicas paralelamente à tentativa de tomada de controle da companhia é, em nossa opinião, inclusive uma tarefa decorrente dos deveres legais impostos pelos artigos 153 a 158 da Lei $n^{\circ} 6.404 / 76$ aos administradores das companhias." ${ }^{182}$

Entretanto, diversamente do que se dá nos EUA, o eventual acordo entre o cavaleiro branco e a administração não deve ser pautado única e exclusivamente pela maximização do valor dos acionistas, devendo, por óbvio, ser respeitado o interesse social.

Analisadas as possibilidades de atuação do conselho de administração nas tomadas hostis, faremos um breve relato de alguns casos que podem levantar pertinentes discussões referentes ao objeto do presente estudo.

De fato, conforme já mencionado, a experiência brasileira é quase inexistente em relação a tomadas hostis de controle quando comparada com aquela desenvolvida nos Estados Unidos. Contudo, alguns casos relativamente recentes tangenciam, quando não atingem, alguns pontos do objeto do presente estudo. Assim, passaremos a um breve relato de três casos que poderão levantar questões interessantes para a análise da atuação

\footnotetext{
${ }^{181}$ SILVA, Carlos Alexandre Lobo e. A evolução da aquisição de controle de companhias abertas no Brasil. In: SILVA, Alexandre Couto [coordenador]. Direito societário. São Paulo: Saraiva, 2013. p. 249.

182 NASCIMENTO, João Pedro Barroso do. Medidas Defensivas à Tomada de Controle de Companhias. São Paulo: Quartier Latin, 2011. p. 169.
} 
do conselho de administração quando da ocorrência de ofertas públicas (não necessariamente de caráter hostil).

O primeiro dos casos que analisaremos será o conhecido Caso Vivendi. Em julho de 2008, a GVT tinha suas ações ordinárias listadas no segmento do Novo Mercado da BM\&FBovespa (atual B3 S.A. - Brasil, Bolsa, Balcão), e possuía um capital social pulverizado, de forma que restava configurado um controle minoritário detido por três acionistas que em conjunto detinham $30,03 \%$ do seu capital social.

Tal companhia tinha em seu estatuto social uma cláusula de proteção à dispersão acionária cujo gatilho era de $15 \%$, ou seja, aquele que atingisse uma participação acionária de $15 \%$ do capital social com direito a voto da GVT deveria formular uma oferta pública para adquirir as demais ações de emissão da companhia. Segundo o dispositivo estatutário, o preço a ser ofertado deveria ser pelo menos equivalente ao maior dentre: (i) $125 \%$ da cotação mais alta atingida nos últimos 12 meses anteriores à OPA; (ii) $125 \%$ do valor mais alto já pago pelo ofertante por ações de emissão da GVT; ou (iii) o valor econômico apurado por laudo de avaliação.

Em setembro de 2009, foi divulgado pela GVT um Fato Relevante que informava que o grupo Vivendi havia celebrado um acordo com os controladores minoritários da GVT, que o permitiria lançar uma OPA para adquirir $100 \%$ do capital votante da GVT ao preço de $\mathrm{R} \$ 42,00$ por ação. Ademais, teriam sido estabelecidas ainda diversas condições, dentre as quais, a dispensa da aplicação da mencionada cláusula de proteção à dispersão acionária, uma vez que o preço então ofertado não atendia aos parâmetros estabelecidos por tal dispositivo estatutário.

Em sequência, quase um mês depois da publicação do referido Fato Relevante, foi anunciado pela Telesp o lançamento de uma OPA para aquisição do controle da GVT ao preço de $\mathrm{R} \$ 48,00$ por ação. Para tanto, também fora exigida a dispensa da aplicação da cláusula de proteção à dispersão acionária por meio de decisão assemblear. 
Passado pouco tempo, o conselho de administração da GVT publicou um novo Fato Relevante no qual informava que seus membros haviam se manifestado unanimemente favoráveis à OPA da Telesp e que deliberaram convocar uma assembleia geral extraordinária para que os acionistas da GVT decidissem acerca da dispensa da cláusula de proteção à dispersão acionária a qualquer oferta pública realizada por um "ofertante qualificado" 183 , que estivesse disposto a pagar pelo menos $\mathrm{R} \$ 48,00$ por ação de emissão da GVT em dinheiro.

Reunidos em assembleia geral extraordinária, os acionistas, munidos das informações contidas na proposta da administração da GVT, aprovaram a dispensa da aplicação da cláusula de proteção à dispersão acionária, permitindo, por conseguinte, a realização da OPA da Telesp ou de uma outra OPA concorrente que se desse nos termos acima delineados.

Todavia, em novembro daquele mesmo ano, publicou-se um novo Fato Relevante que informava que os controladores da GVT haviam anunciado que a Vivendi teria adquirido ações e opções sobre ações de emissão da GVT, ao preço de $\mathrm{R} \$ 56,00$ por ação, que, em conjunto, atingiam $57,5 \%$ do capital votante da companhia.

Em resumo: inobstante a formulação da OPA da Telesp, a Vivendi adquiriu de maneira privada uma participação acionária que os conferia status de acionistas controladores. Desse modo, uma vez que mais de 50\% mais uma ação integrante do capital votante da GVT passava a se encontrar nas mãos de um único acionista, a OPA da Telesp se exauriu por perda de objeto, vista a impossibilidade de aquisição de controle por tal meio.

A partir de tal atuação da Vivendi, deu-se origem ao Processo Administrativo Sancionador CVM n. ${ }^{\circ}$ RJ2010/2419 que foi encerrado

\footnotetext{
183 Definiu-se como "ofertante qualificado" aquele que tivesse obtido a anuência da Agência Nacional de Telefonia - ANATEL para adquirir o controle da GVT.
} 
através da celebração de um Termo de Compromisso no qual a Vivendi foi obrigada a pagar $\mathrm{R} \$ 150.000 .000,00 .{ }^{184}$

No que toca o objeto do presente estudo, observa-se que o conselho de administração não atuou de maneira passiva perante o desenvolvimento das negociações. Pelo contrário, manifestou-se de maneira fundamentada a favor de uma oferta pública e, por entender a adequação desta, deliberou a convocação de uma assembleia geral, possibilitando aos acionistas um ambiente de debate acerca da conveniência ou não da oferta formulada, além de reduzir a pressão sobre eles exercida através do fornecimento de diversas informações que pelo conselho de administração foram colhidas e utilizadas para aferir e posteriormente comunicar aos acionistas se, na visão de tal órgão social, a oferta pública era ou não adequada. ${ }^{185}$

É dizer, o conselho de administração da GVT cumpriu parte de seu dever de diligência ao munir-se de informações acerca da oferta formulada. Tendo concluído que a OPA não representava uma ameaça ao interesse social e que o valor ofertado estava adequado, convocou uma assembleia geral para que os acionistas pudessem dispensar a aplicação de um dispositivo que apenas obstaria o sucesso de uma oferta adequada, em prejuízo aos próprios acionistas da GVT.

O segundo caso brasileiro que analisaremos será o Caso DASA. No final do ano de 2013, a Diagnósticos da América S.A. ("DASA”), era uma companhia cujo capital social estava disperso no mercado, de modo que seu free float estava em um patamar acima de $50 \%$ e não se podia identificar um controlador definido.

Nessa época, o art. 45 do estatuto social da DASA continha uma cláusula de proteção à dispersão acionária cujo gatilho era de $15 \%$, tal qual no caso Vivendi. A OPA estatutária a ser formulada em razão do disparo do

\footnotetext{
184 Decisão do Colegiado de 09.12.2010. Disponível em: <http://www.cvm.gov.br/decisoes/2010/20101209_R1/20101209_D01.html>. Acesso em: 09.07.2018.

185 Adiantamos, desde logo, que um dos importantes aspectos do Caso Vivendi, para fins do presente estudo, trata-se da possiblidade de dispensa de aplicação de uma cláusula de proteção à dispersão acionária.
} 
referido gatilho deveria ser: (i) dirigida indistintamente aos acionistas da DASA; (ii) realizada em leilão na BM\&FBovespa; (iii) pelo preço determinado na forma do parágrafo segundo deste dispositivo estatutário ${ }^{186}$; e (iv) paga à vista em moeda corrente nacional.

Nessa conjuntura, a Cromossomo, cujos controladores já detinham 23,59\% do capital votante da DASA, lançou uma OPA para adquirir pelo menos $26,41 \%$ mais 1 ação das ações com direito a voto de emissão da DASA, de modo que, em caso de sucesso, os controladores da Cromossomo passariam a deter $50 \%$ mais 1 ação de emissão da DASA, tomando, por consequência, seu controle acionário, nos termos do art. 116, LSA.

Em vista, do percentual mínimo ofertado $(26,41 \%)$ ser relativamente baixo, a Cromossomo passou a perceber que seria possível que os acionistas da DASA rejeitassem a oferta formulada. Assim, de forma a aumentar seu poder de persuasão, a Cromossomo aditou o edital original da OPA. Para tanto, tendo a autorização da CVM, foi estabelecido um procedimento diferenciado de unificação de ofertas públicas para aquisição de até $100 \%$ das ações emitidas pela DASA.

\footnotetext{
186 "Parágrafo Segundo - O preço de aquisição na OPA de cada ação de emissão da Companhia não poderá ser inferior ao maior valor entre (i) o Valor Econômico apurado em laudo de avaliação; (ii) 100\% (cem por cento) do preço de emissão das ações em qualquer aumento de capital realizado mediante distribuição pública ocorrido no período de 12 (doze) meses que anteceder a data em que se tornar obrigatória a realização da OPA nos termos deste Artigo 45, devidamente atualizado pelo IPCA até o momento do pagamento; (iii) 100\% (cem por cento) da cotação unitária média das ações de emissão da Companhia, durante o período de 90 (noventa) dias anterior à realização da OPA, ponderada pelo volume de negociação, na bolsa de valores em que houver o maior volume de negociações das ações de emissão da Companhia; e (iv) $100 \%$ (cem por cento) do maior valor pago pelo Acionista Comprador por ações da Companhia em qualquer tipo de negociação, no período de 12 (doze) meses que anteceder a data em que se tornar obrigatória a realização da OPA nos termos deste Artigo 45. Caso a regulamentação da CVM aplicável à OPA prevista neste caso determine a adoção de um critério de cálculo para a fixação do preço de aquisição de cada ação da Companhia na OPA que resulte em preço de aquisição superior, deverá prevalecer na efetivação da OPA prevista aquele preço de aquisição calculado nos termos da regulamentação da CVM".

Conforme versão do estatuto social da DASA de 22.04.2013. Disponível em: < http://siteempresas.bovespa.com.br/consbov/ArquivoComCabecalho.asp?motivo=\&protocolo=376 $\underline{605 \& \text { funcao }=\text { visualizar } \& \text { Site }=C}>$. Acesso em: 09.07.2018.
} 
Dessa forma, duas ofertas públicas se dariam modo unificado: (i) a OPA com base no art. $2^{\circ}$, IV da Instrução CVM n. ${ }^{\circ} 361 / 02^{187}$; e (ii) a OPA do art. 257 da LSA. Enquanto a última possibilitaria à Cromossomo deter um controle majoritário, a primeira a permitiria o exercício de um controle minoritário.

O valor ofertado pela Cromossomo foi de $\mathrm{R} \$ 15,00$ por ação, que à época não só estava acima da cotação média, como também era 22,90\% superior ao valor determinado com base na cláusula de proteção à dispersão acionária do estatuto social da DASA e atendia a todos os outros critérios estabelecidos em tal dispositivo estatutário: (i) ser dirigida indistintamente a todos os acionistas; (ii) efetivada em leilão a ser realizado na BM\&FBovespa; e (iii) paga à vista em moeda corrente nacional.

Em 13 de janeiro de 2014, o conselho de administração da DASA, de forma fundamentada, manifestou-se favoravelmente à OPA da Cromossomo. Ocorre, contudo, que após a realização bem-sucedida da OPA da Cromossomo, o conselho de administração levantou discussão acerca da necessidade de uma nova oferta pública para aquisição de ações a ser lançada pela Cromossomo, esta obrigatória, para atendimento da cláusula de proteção à dispersão acionária do estatuto da DASA (cujos requisitos, relembrados, já teriam sido atendidos) ${ }^{188}$, sob pena de ter seus direitos suspensos, nos termos do art. 120, $\mathrm{LSA}^{189}$.

Tendo em vista a divergência com o conselho de administração da DASA, a Cromossomo recorreu à Câmara de Arbitragem do Mercado da BM\&FBovespa (“CAM") 190 .

\footnotetext{
187 "OPA voluntária: é a OPA que visa à aquisição de ações de emissão de companhia aberta, que não deva realizar-se segundo os procedimentos específicos estabelecidos nesta Instrução para qualquer OPA obrigatória referida nos incisos anteriores".

188 Fato relevante da DASA de 31.01.2014. Disponível em: $\langle$ http://www.dasa3.com.br/sites/default/files/2017-01/2422.pdf > . Acesso em: 08.07.2018.

${ }^{189}$ Art. 120. A assembléia-geral poderá suspender o exercício dos direitos do acionista que deixar de cumprir obrigação imposta pela lei ou pelo estatuto, cessando a suspensão logo que cumprida a obrigação.

190 Fato relevante da DASA de 07.03.2014. Disponível em: $\langle$ http://www.dasa3.com.br/sites/default/files/2017-01/2472.pdf > . Acesso em: 08.07.2018.
} 
Para embasar suas alegações, a Cromossomo enviou, dentre outros, um parecer da lavra do ex-presidente da CVM, Marcelo Trindade, datado de 7 de fevereiro de $2014^{191}$. De acordo com o parecer, a OPA estatutária da DASA tinha por objetivo a proteção da dispersão de sua base acionária, e, ao mesmo tempo, lidava com a possibilidade de ocorrer tanto a consolidação do poder de controle (majoritário ou minoritário) nas mãos de um acionista ou grupo de acionistas (o que poderia vir a resultar na alteração da condução dos negócios e atividades sociais da DASA) quanto a perda de liquidez das ações de sua emissão (o que levaria, por consequência, à redução da possibilidade dos acionistas da DASA alienarem suas ações a um valor justo).

Considerando o objetivo e os riscos contidos na realização da OPA estatutária prevista na cláusula de proteção à dispersão acionária inclusa no estatuto social da DASA, e a já realização das ofertas públicas da Cromossomo, o grande questionamento suscitado passou a ser se tais ofertas públicas outrora realizadas, por si só, já teriam cumprido ou não as finalidades da OPA estatutária da DASA, de forma a acarretar na dispensa desta.

A resposta do parecer foi de que a dispensa seria devida, uma vez que, conforme supramencionado, as ofertas públicas feitas pela Cromossomo por meio de procedimento unificado respeitaram os requisitos objetivos elencados na cláusula de proteção à dispersão acionária da DASA. Dessa forma, por possibilitar aos acionistas da DASA a liquidez que se buscava garantir por meio do referido dispositivo estatutário, as ofertas públicas da Cromossomo fizeram com que a obrigação estipulada no estatuto social da DASA tivesse sido cumprida, impossibilitando que esta pudesse ser novamente requerida.

Ao cabo, concordando com as explanações contidas nos pareceres apresentados pela Cromossomo, o tribunal arbitral deliberou pela

\footnotetext{
${ }^{191}$ Disponível em: http://www.mzweb.com.br/opadasa/arquivos/OPA_DASA_PareceresLegais_P T.pdf> Acesso em: 08.07.2018.
} 
procedência do pedido da Cromossomo, declarando que não havia, por parte da requerente, a necessidade de realização de uma nova oferta pública para aquisição de ações de emissão da DASA.

No Caso DASA, também é possível perceber que o conselho de administração da companhia não se quedou inerte. Foi realizada, a seu pedido, a elaboração de um parecer por meio do qual tal órgão social manifestou-se favoravelmente à oferta formulada por nela, com base nas informações colhidas, não visualizar uma ameaça ao interesse social.

Além disso, o conselho de administração, munido de parecer elaborado por seus assessores jurídicos, por entender (ainda que de maneira equivocada em nossa opinião) pela necessidade de aplicação da cláusula de proteção à dispersão acionária, solicitou à Cromossomo a realização de uma nova oferta pública, discordando publicamente, portanto, do então acionista controlador da DASA, o que, na sua alegada visão, teria sido necessário para fins de cumprimento dos seus deveres fiduciários ${ }^{192}$.

O último caso que trataremos será o recente Caso Eletropaulo que envolveu a aquisição da Eletropaulo Metropolitana de Eletricidade de São Paulo S.A. ("Eletropaulo") pela Enel Brasil Investimentos Sudeste S.A. ("Enel") e que será de enorme valia para a análise da atuação do conselho de administração em ofertas públicas concorrentes.

Em janeiro de 2018, a Eletropaulo era uma companhia aberta que não possuía controlador. Seu capital social era composto apenas por ações ordinárias, das quais mais de 47,7\% encontravam-se dispersas no mercado. Seus dois acionistas que detinham maiores parcelas do capital social eram AES Holding Brasil Ltda. e BNDES Participações S.A. - BNDESPAR que

\footnotetext{
${ }^{192}$ Essa não foi a única vez que o conselho de administração da DASA se manifestou de forma contrária a uma decisão do acionista controlador. Em 2015, a Cromossomo formulou uma nova OPA, porém, tal oferta pública destinava-se à retirada da DASA do segmento do Novo Mercado. Como se lê do Memorando n. ${ }^{\circ}$ 73/2015-CVM/SRE/GER-1, o "Conselho de Administração da Companhia se reuniu em 16/05/2015, para deliberar sobre a apresentação à assembleia geral da proposta dos Controladores quanto à realização da OPA ("RCA"). Em cumprimento ao disposto no artigo 20, XIII, do Estatuto Social da Companhia, que determina a necessidade de manifestação do Conselho de Administração sobre qualquer assunto a ser submetido à assembleia geral da Companhia, posicionou-se contrariamente ao pretendido pelos Controladores por entender que esta proposta não atendia ao melhor interesse da Companhia".
} 
possuíam, respectivamente, $16,83 \%$ e $18,73 \%$ das ações de emissão da Eletropaulo.

À época, o estatuto social da Eletropaulo previa uma cláusula de proteção à dispersão acionária cujo gatilho era de 30\%. Tal dispositivo previa ainda que a obrigatoriedade de realização da OPA estatutária poderia ser dispensada pela "Assembleia Geral da Companhia, ficando impedido de votar o acionista que tenha interesse conflitante com a matéria. Nesta hipótese, o Conselho de Administração deverá convocar a Assembleia Geral para deliberar a supressão do disposto neste artigo, no todo ou em parte, hipóteses em que deverá disponibilizar aos acionistas as informações de conhecimento da administração da Companhia que justifiquem tal supressão e a manifestação do Conselho de Administração sobre a matéria" $^{193}$

Em 14 de março de 2018, a Eletropaulo divulgou Fato Relevante reiterando que, dentre as diversas alternativas para financiamento da companhia, estava a possibilidade de realização de uma oferta pública de distribuição de ações, mas que, entretanto, não havia até então qualquer tipo de definição acerca da realização ou não de tal oferta ${ }^{194}$.

Em 22 de março de 2018, foi divulgado novo Fato Relevante no qual a Eletropaulo informa existência de uma proposta da Enel relativa ao investimento da The AES Corporation (controladora da AES Holding Brasil Ltda.) e à participação da Enel na possível oferta pública de distribuição de ações da Eletropaulo.

Em 5 de abril de 2018, a Eletropaulo informou, por meio de Fato Relevante, que a Energisa S.A. ("Energisa") teria lançado uma oferta pública para adquirir a totalidade das ações de emissão da Eletropaulo (salvo pelas ações em tesouraria) ao preço de $\mathrm{R} \$ 19,38$ por ação (“OPA

\footnotetext{
${ }^{193}$ Conforme $\S 10^{\circ}$ do artigo 44 do estatuto social da Eletropaulo. Conforme versão de 11.01.2018. Disponível em: <http://siteempresas.bovespa.com.br/consbov/ArquivoComCabecalho.asp?motivo $=\&$ protocolo $=593603 \&$ funcao $=$ visualizar $\&$ Site $=C>$. Acesso em 08.07.2018. ${ }^{194}$ Disponível em: <http://ri.eletropaulo.com.br/list.aspx?idCanal=8MI1 Y3i/ZOZvjHuDhor4ig >. Acesso em 08.07.2018.
} 
Energisa"), e que, em decorrência disto, seu conselho de administração elaboraria um parecer acerca da OPA Energisa, nos termos do já mencionado art. 21 do Regulamento do Novo Mercado.

Em 16 de abril de 2018, foi encerrada a reunião do conselho de administração que deliberou pela realização de uma oferta pública de distribuição primária de ações de emissão da Eletropaulo ("Oferta Primária"), e a celebração de um acordo de investimento ("Acordo de Investimento") entre a Eletropaulo e a Neoenergia S.A. ("Neoenergia").

Na mesma data, foi publicado Fato Relevante no qual a Eletropaulo informava ter celebrado o Acordo de Investimento, por meio do qual a Neoenergia teria firmado compromisso de subscrever as ações objeto da Oferta Primária ao preço de $\mathrm{R} \$ 25,51$ por ação. Contudo, o Acordo de Investimento estava sujeito à aprovação do conselho de administração da Eletropaulo em reunião a ser realizada em 20 de abril de 2018. Conforme informado neste Fato Relevante, caso o preço ofertado na Oferta Primária fosse igual ou inferior aos $\mathrm{R} \$ 25,51$ por ação aceitos pela Neoenergia, esta estaria obrigada a adquirir $80 \%$ das ações distribuídas pela Oferta Primária após eventual exercício do direito de prioridade dos então acionistas da Eletropaulo. Por outro lado, caso o preço ofertado na Oferta Primária fosse superior a $\mathrm{R} \$ 25,51$ por ação, a Neoenergia poderia ou não subscrever até $80 \%$ de tais ações. Ademais, após a aprovação do conselho de administração da Eletropaulo, a Neoenergia estaria obrigada a formular uma oferta pública para aquisição de controle da Eletropaulo.

Além disso, conforme informado em tal Fato Relevante, $\underline{\text { o Acordo de }}$ Investimento seria automaticamente extinto, dentre outras hipóteses, (i) caso ocorresse a liquidação de outra oferta pública de aquisição de ações de emissão da Eletropaulo na qual um terceiro adquirisse um número de ações que representasse a maioria do capital social da Eletropaulo, ou (ii) caso a Oferta Primária fosse revogada pela Eletropaulo, através de decisão do seu conselho de administração, no cumprimento de seus deveres fiduciários. 
Um dia depois, isto é, em 17 de abril de 2018, foi publicado novo Fato Relevante pela Eletropaulo no qual se divulgava que a Enel havia lançado uma oferta pública voluntária concorrente para aquisição de até a totalidade das ações ordinárias de emissão da Eletropaulo, ao preço de R\$ 28,00 por ação (“OPA Enel”), e que, em razão deste fato, seu conselho de administração elaboraria um parecer acerca desta nova OPA, também nos termos do art. 21 do Regulamento do Novo Mercado da mesma forma que se informou no Fato Relevante divulgado em 5 de abril de 2018 quando fora anunciada a OPA Energisa ao preço de $\mathrm{R} \$ 19,38$ por ação.

Assim, três ofertas estavam na mesa: (i) a OPA Energisa (e reiterada através de divulgação de Fato Relevante em 17 de abril de 2018) ao preço de $\mathrm{R} \$ 19,38$ por ação; (ii) a da Neoenergia decorrente do Acordo de Investimento ao preço de $\mathrm{R} \$ 25,51$ por ação; e (iii) a OPA Enel ao preço de $\mathrm{R} \$ 28,00$ por ação.

Ocorre que, em 20 de abril de 2018, adveio novo Fato Relevante da Eletropaulo, através do qual divulgava-se que a Neoenergia havia lançado uma OPA concorrente ao preço de R $\$ 29,40$ por ação ("OPA Neoenergia").

Nesta mesma data, também por meio de Fato Relevante, a Eletropaulo informava que havia recebido um ofício da $\mathrm{CVM}^{195}$, no qual se exigia que a Eletropaulo e seus administradores, à luz dos seus deveres fiduciários, se manifestassem até 23 de abril de 2018 acerca do sentido de prosseguir com a Oferta Primária. Ou seja, considerando que em andamento um forte processo competitivo que restava por elevar cada vez mais a cotação das ações de emissão da Eletropaulo, questionou a autarquia os motivos pelos quais a Oferta Primária deveria prosseguir, o que, caso ocorresse, extinguiria a competição referida, e, por consequência, a elevação dos preços.

A resposta a tal Ofício se deu através de um Comunicado ao Mercado, publicado no último dia do prazo determinado pelo Ofício

${ }^{195}$ Ofício n. $^{\circ}$ 98/2018/CVM/SRE/GER-1. 
enviado pela CVM. ${ }^{196}$ Neste documento, o conselho de administração da Eletropaulo informou que à época em que havia apenas a OPA Energisa e as negociações do Acordo de Investimento com a Neoenergia, em virtude de diversas partes estarem interessadas em investir na Eletropaulo, foi preciso que tal órgão societário buscasse um "ponto de equilíbrio" entre o interesse dos acionistas em obter o melhor preço possível para a alienação de suas participações e a necessidade da Eletropaulo reforçar sua estrutura de capital, em vista das suas obrigações de curto prazo ${ }^{197}$.

Em outras palavras, era preciso ponderar os interesses em jogo. Como vimos, os administradores têm deveres fiduciários para com a companhia, e não em relação aos seus acionistas. Dessa forma, era preciso que a atuação do conselho de administração se desse de forma a atender o interesse social que envolverá tanto o interesse da própria companhia, em manter o seu desenvolvimento, quanto o de seus acionistas, que desejam a maximização de seus investimentos.

Assim, havia, de um lado, a OPA Energisa que ofertava $\mathrm{R} \$ 19,38$ por ação, e, por outro lado, havia o Acordo de Investimento, que, conforme manifestação do conselho de administração, foi, à época, o meio encontrado para atingir o tal "ponto de equilíbrio", pois, dessa forma, tendo obtido o compromisso de ancoragem da Neoenergia no que toca à OPA Primária ao preço de $\mathrm{R} \$ 25,51$ por ação, além da realização de uma outra OPA a preço idêntico, o conselho de administração havia conseguido atender às exigências de capitalização da Eletropaulo, bem como conseguir uma

\footnotetext{
${ }^{196}$ Disponível em: 〈http://ri.eletropaulo.com.br/list.aspx?idCanal=8MI1Y3i/ZOZvjHuDhor4ig〉. Acesso em 08.07.2018.

197 "Com este novo evento, e a confirmação do interesse de terceiros, incluindo a Enel e a Neoenergia, de ancorarem o Follow-on e, adicionalmente, garantirem aos acionistas a possibilidade de venda de suas ações por preço ainda mais expressivo do que aquele oferecido pela Energisa, o Conselho de Administração, tomando em conta os seus deveres fiduciários, buscou um ponto de equilíbrio entre o interesse dos acionistas em obter o melhor preço, no âmbito da OPA iniciada pela Energisa, e a necessidade da Companhia de "reforçar sua estrutura de capital, considerando suas obrigações de curto prazo" 1 , através da aprovação do aumento de capital em questão, no dia 16 de abril, a ser realizado na forma da Instrução ${ }^{\circ} 476$, com ancoragem e a obrigação do âncora de realizar oferta pública concorrente (“Oferta 476 " ou, como já utilizado anteriormente, "Follow-on")." Conforme Comunicado ao Mercado da Eletropaulo, datado de 23.04.2018. Disponível em: <http://ri.eletropaulo.com.br/list.aspx?idCanal=8MI1 Y3i/ZOZvjHuDh or4ig==>. Acesso em 09.07.2018.
} 
maximização do valor das ações dos acionistas em 31,6\% quando comparada com a OPA Energisa.

Em relação à OPA Enel, que também previa a capitalização da Eletropaulo, identicamente ao que se daria por meio do procedimento previsto no Acordo de Investimento com a Neoenergia, o conselho de administração da Eletropaulo, de forma a defender a manutenção da Oferta Primária defendeu, dentre outros argumentos, que a OPA Enel estava condicionada à aquisição da maioria das ações de emissão da Eletropaulo, enquanto que a OPA Neoenergia não possuía limite mínimo, o que aumentaria a possibilidade de venda das ações na Oferta Primária. ${ }^{198}$

Além disso, quando comparadas, a OPA Neoenergia, na visão do conselho de administração da Eletropaulo, seria mais vantajosa no que se refere ao prazo para capitalização. A OPA Energisa estabelecia que o aumento de capital seria efetuado em prazo de 180 dias contado da data do leilão. Por sua vez, OPA Enel originalmente estabeleceu que tal prazo seria de 60 dias contados da última aprovação regulatória ${ }^{199}$. A alteração de tal prazo foi objeto de aditamento ao edital da OPA Enel, que passou a prever que o aumento de capital se daria em 30 dias. No entanto, tal edital aludiria à possibilidade de existência de direito de preferência com prazo legal de 30 dias, o que, ao fim, faria com que o prazo permanecesse o mesmo.

Assim, o conselho de administração da Eletropaulo se manifestou afirmando que o procedimento previsto no Acordo de Investimento, conjugado com a OPA Neoenergia, permitiria até 3 de maio "a obtenção de recursos para a Companhia, sem aumentar os seus índices de endividamento, sem incorrer em custos financeiros adicionais com empréstimos e sem ameaçar atingir os limites de seus covenants financeiros", e que, portanto, caberia "exclusivamente à Enel, se atenta ao

\footnotetext{
${ }^{198}$ Ao cabo, como veremos adiante, a OPA Neoenergia também passou a ser condicionada ao mesmo limite mínimo previsto na OPA Enel.

${ }^{199}$ Além da aprovação do CADE, por se tratar de concessionária de serviços de distribuição de energia elétrica, a mudança de controle da Eletropaulo deveria ser autorizada também pela ANEEL, nos termos do art. 27 de Lei n. ${ }^{\circ} 8.987$ de 13 de fevereiro de 1995.
} 
melhor interesse dos acionistas da Eletropaulo e à competitividade da oferta, fazer uma oferta de preço mais atraente e, se e quando bemsucedida, realizar a capitalização como já contratado por uma de suas concorrentes".

Por fim, nesse Comunicado ao Mercado, a administração da Eletropaulo ressaltou ainda que não tinha "interesse na vitória de um ou outro competidor, podendo a qualquer momento reavaliar o seu posicionamento, sempre com o objetivo de obter o melhor valor para todos os seus acionistas, respeitadas as necessidades de capital da Companhia para a adequada execução de seu Plano de Negócios assegurando a qualidade requerida na prestação de seus serviços de interesse público, a todos os seus consumidores e sociedade em geral abrangida". ${ }^{200}$

Como visto, tudo parecia indicar que a Neoenergia sairia vitoriosa. Entretanto, o caso ganhou uma reviravolta em 25 de abril (mesmo dia em que a Enel aumentou o preço da OPA Enel para $R \$ 32,00$, e a Neoenergia aumentou o preço da OPA Neoenergia para $\mathrm{R} \$ 32,10$ ), quando ocorreu um evento que terá forte impacto na análise do caso em comento, especialmente em relação ao objeto do presente estudo.

Nesta data, foi publicado um novo Fato Relevante que informava que o conselho de administração da Eletropaulo havia deliberado, em reunião realizada naquele mesmo dia ("RCA 25.04.2018"), pelo cancelamento da Oferta Primária a fim de permitir "a melhor evolução da competitividade entre as ofertas públicas para aquisição de ações da Companhia atualmente em curso (bem como outras novas potenciais ofertas), buscando, assim, maximizar valor para seus acionistas, sem prejuízo do atendimento das necessidades de capitalização da Companhia".

\footnotetext{
${ }^{200}$ Em relação ao interesse social, aspecto que trataremos à frente, é interessante notar, desde logo, que tal declaração demonstra preocupação com os interesses não só dos acionistas (maximização de seus investimentos), como também com os da companhia (manutenção do seu desenvolvimento) e de seus stakeholders (como, por exemplo, seus credores, consumidores e até a comunidade na qual a companhia se insere).
} 
Transcreveremos abaixo as principais passagens da ata da reunião do conselho de administração da Eletropaulo realizada em 25 de abril de 2018:

"Os conselheiros discutiram a realização da oferta pública de aquisição de ações para aquisição de controle da Companhia divulgada pela Enel Brasil Investimentos Sudeste S.A. ("OPA" e "Enel") em 17 de abril de 2018, conforme aditada em 20 e em 24 de abril de 2018, de sorte, inclusive, a garantir a capitalização da Companhia em montante de pelo menos $\mathrm{R} \$ 1.5 \mathrm{bi}$, vis-à-vis a Oferta Pública de Distribuição Primária de Ações Ordinárias de Emissão da Companhia com esforços restritos de colocação, objeto de fato relevante divulgado em 16 de abril de 2018 ("Oferta Restrita"). Em vista do recebimento, durante a reunião, do Ofício CVM n ${ }^{\circ}$ 98/2018/CVM/SRE/GER-1, decidiu-se suspender os trabalhos para análise detalhada da documentação recebida e preparação da manifestação solicitada no referido ofício ("Comunicado ao Mercado"). Retomados os trabalhos em 23 de abril de 2018, às 12h, o Conselho de Administração apreciou e aprovou o Comunicado ao Mercado então divulgado pela Companhia na mesma data, e decidiu retomar os trabalhos às $18 \mathrm{~h}$ do dia 25 de abril de 2018 , data limite estabelecida pela Enel para que fosse cancelada a Oferta Restrita, como condição de validade da OPA. Retomados os trabalhos em 25 de abril de 2018, às 18h, registrou-se novo aditamento, pela Enel, à OPA, aumentando o preço oferecido por ação, conforme imediatamente divulgado pela Companhia, nos termos da regulamentação em vigor.

(...)

Diante do fato novo ocorrido, constituído pela proposta mais favorável da Enel, que também contempla a capitalização da Companhia, o Conselho de Administração da Companhia, no melhor exercício do seu dever fiduciário, entendeu que o cancelamento da Oferta Restrita permitirá a melhor evolução da competitividade entre as ofertas públicas para aquisição de ações da Companhia atualmente em curso, mantendo-se vigente todas as três ofertas até agora apresentadas (bem como permitindo outras novas potenciais ofertas), buscando, dessa forma, maximizar valor para seus acionistas, sem prejuízo do atendimento das necessidades de capitalização da Companhia. Em consequência, os membros do Conselho de Administração, com base nas informações prestadas, nas discussões havidas e nos esclarecimentos prestados, aprovaram, por unanimidade de votos, registrada a abstenção do conselheiro Erik da Costa Breyer e as declarações de voto dos conselheiros Erik da Costa Breyer e Marcelo Gasparino da Silva, arquivadas na sede da Companhia, o cancelamento, na data de hoje, da Oferta Restrita. A decisão ora tomada não se altera com o eventual surgimento de novas propostas, o que só fará confirmar a competitividade que deverá ser mantida no leilão, em benefício progressivo do conjunto de acionistas."

Assim, tendo em vista o processo competitivo que estava ocorrendo e elevando a cotação das ações de emissão da Eletropaulo, sem prejuízo da manutenção das propostas de capitalização, deliberou o conselho de administração da Eletropaulo por cancelar a Oferta Primária prevista no Acordo de Investimento. 
Após um aumento no valor ofertado na OPA Enel que passou de $\mathrm{R} \$ 32,10$ para $\mathrm{R} \$ 32,20$ por ação, foi publicado, em 30 de abril de 2018, um novo Comunicado ao Mercado, no qual a Eletropaulo informava que seu conselho de administração se manifestaria até 13 de maio de 2018 acerca da OPA Enel e OPA Neoenergia.

Em 3 de maio de 2018, um novo Fato Relevante foi publicado pela Eletropaulo que informava que havia recebido o Ofício $n$. $^{\circ}$ 113/2018/CVM/SRE/GER-1, enviado pela CVM, que exigia que os editais da OPA Energisa, OPA Enel, e OPA Neoenergia fossem aditados até 7 de maio de 2018 para refletir que: (i) o leilão conjunto dessas OPAs, bem como de qualquer outra que viesse a ser lançada, ocorreria em 4 de junho de 2018; (ii) que o prazo máximo para apresentação de uma eventual nova OPA concorrente seria até 14 de maio de 2018; (iii) que os preços só poderiam ser aumentados até 24 de maio de $2018^{201}$; (iv) que poderia haver interferência compradora no leilão caso o interferente manifestasse sua intenção até 24 de maio de 2018; e (v) caso houvesse divulgação de tal intenção, os ofertantes poderiam elevar seus preços caso de fato o interferente apresente sua oferta na data do leilão. ${ }^{202}$

Em seguida, no dia 4 de maio de 2018, Eletropaulo publicou Fato Relevante no qual informava que a OPA Energisa havia sido revogada. Assim, a disputa pelo controle da Eletropaulo ficou entre a Enel e a Neoenergia.

Em 8 de maio de 2018, novo Fato Relevante foi publicado pela Eletropaulo. Neste documento, era informado que a Neoenergia havia

\footnotetext{
${ }^{201}$ Conforme Fato Relevante de 29 de maio de 2018 da Eletropaulo, o Colegiado da CVM fixou que o aumento dos preços dos ofertantes poderia ser divulgado até 30 de maio de 2018 (Ofício n. ${ }^{\circ}$ 149/2018/CVM/SRE/GER-1).

${ }^{202}$ Tal Ofício decorreu da decisão do Colegiado da CVM, de 2 de maio de 2018, no âmbito do Proc. SEI 19957.003818/2018-41. O Diretor Gustavo Gonzalez divergiu da decisão proferida "por entender que a possibilidade de combinação de diferentes mecanismos de disputa de preço não seria adequada, pois daria ao potencial interferente uma condição mais favorecida decorrente do fato de que esse terá uma informação adicional, desconhecida dos demais, referente à sua intenção de interferir, e, consequentemente, acerca do procedimento que seria ao final utilizado para a determinação do preço da OPA." Disponível em: <http://www.cvm.gov.br/decisoes/2018/20180502_R1/20180105_D1024.html〉. Acesso em: 09.07.2018.
} 
solicitado a instauração de um procedimento arbitral perante a CAM cujo objeto se referiria a questão decorrentes do Acordo de Investimento. Nessa seara, a Eletropaulo se manifestou no sentido de que as alegações formuladas pela Neoenergia seriam improcedentes tendo em vista que o Acordo de Investimento teria sido integralmente cumprido. ${ }^{203}$

Em 30 de maio de 2018, foi publicado um parecer do conselho de administração da Eletropaulo acerca da OPA Enel e OPA Neoenergia. Por meio deste documento, o conselho de administração, embora informando que a análise da conveniência das OPAs se restringia apenas ao preço ofertado, destacou (i) que o edital da OPA Enel previa que a capitalização de pelo menos $\mathrm{R} \$ 1.500 .000 .000,00$ ocorreria mesmo que a OPA Enel e a OPA Neoenergia não tivessem sucesso, enquanto o Edital da OPA Neoenergia era silente em relação a este aspecto, e (ii) que, enquanto os planos da Enel para o futuro da Eletropaulo envolviam a manutenção desta no Novo Mercado e seu registro de companhia aberta perante a CVM na categoria A, a Neoenergia informava que, em caso de sucesso da OPA Neoenergia, avaliaria a possibilidade de saída do segmento do Novo Mercado, bem como a possibilidade de cancelamento de registro de companhia aberta. Dessa forma, considerando que o preço oferecido na OPA Enel era superior ao que era oferta na OPA Neoenergia, manifestou-se o conselho de administração da Eletropaulo de forma favorável à OPA Enel, e, consequentemente, de modo contrário à OPA Neoenergia.

\footnotetext{
${ }^{203}$ Em razão do sigilo do procedimento arbitral em trâmite, até o fechamento da edição da presente monografia, a única notícia que se tem foi a publicada no Fato Relevante de 24 de maio de 2018 da Eletropaulo, segundo o qual, fora prolatada uma decisão judicial, nos autos da tutela cautelar antecedente n. $^{\circ} 1053718-56.2018 .8 .26 .0100$, em curso perante a $2^{\mathrm{a}}$ Vara Empresarial e Conflitos de Arbitragem do Foro Central da Comarca de São Paulo, que determinou, dentre outras questões que o leilão seria realizado no dia 4 de junho de 2018, "nos moldes já estabelecidos, ocasião em que a Enel e Neonergia poderão concorrer pelo melhor preço, juntamente com eventuais terceiros que tenham manifestado o seu interesse até esta data". Tal decisão, como informa o Fato Relevante de 25 de maio de 2018 da Eletropaulo, foi suspensa.
} 
Em sequência, verificou-se um forte aumento nos preços ofertados, de modo que, ao fim, a OPA Enel e OPA Neoenergia, ofereceram, respectivamente, $\mathrm{R} \$ 45,22$ e $\mathrm{R} \$ 39,53$ por ação. ${ }^{204}$

Ao cabo, no dia 4 de junho de 2018, a saga pela aquisição do controle da Eletropaulo foi encerrada com aquisição de 122.799.289 ações, representativas de $73,4 \%$ do capital votante da Eletropaulo pela Enel ao preço de $\mathrm{R} \$ 45,22$ por ação.

Assim, em relação ao preço inicialmente ofertado pela Enel ( $R \$ 28,00)$, percebe-se uma valorização de cerca de $61,5 \%$ no preço pago. Quando comparado com a primeira oferta feita, isto é, a OPA Energisa (R $\$ 19,38)$, a valorização foi de cerca de 133,33\%.

Em relação ao Caso Eletropaulo acima narrado, o que podemos perceber quanto à atuação do conselho de administração é a existência ou não de tratamento diferenciado entre os ofertantes. Como vimos, o conselho de administração a todo momento ressaltava que, com base nos seus deveres fiduciários, era preciso encontrar um meio de maximizar o valor das ações dos acionistas sem que isso levasse ao prejuízo da capitalização da Eletropaulo.

Acreditamos que esse seja um exemplo caso em que os já delineados Deveres Revlon poderiam ser de grande valia. Como vimos, nosso ordenamento jurídico não possui regras que disciplinem até que ponto podem atuar os administradores, em especial quando se trata de ofertas públicas, sejam elas hostis ou amigáveis.

Dessa forma, frente ao vazio de normas expressas, a análise da atuação dos membros do conselho de administração se dará sob a ótica de seus deveres fiduciários que são regulados pelos arts. 153 a 159 da LSA. Quando confrontados com uma situação em que a oferta para aquisição é iminente, entendemos que os Deveres Revlon poderão servir como princípio que auxiliará a interpretação dos referidos dispositivos, de modo a

${ }^{204}$ Conforme Fato Relevante da Eletropaulo, publicado em 30 de maio de 2018. 
nortear a atuação dos administradores, desde feitas as já mencionadas adaptações ao nosso sistema. Isto é, considerando que no Brasil o dever dos administradores é para com a companhia, e não com seus acionistas, sua atuação não poderá se dar única e exclusivamente no intuito de maximizar o valor dos investimentos realizados pelos acionistas. É preciso que tal maximização se dê em respeito ao interesse social.

No Caso Eletropaulo, enxerga-se, como adiantado, que o conselho de administração lidava com dois interesses. O primeiro interesse era o dos acionistas que queriam que a cotação de suas ações aumentasse ao máximo possível. Por sua vez, o segundo interesse seria aquele da companhia, qual seja, a sua capitalização que a permitiria solver obrigações de curto prazo e possibilitar investimentos de médio e longo prazo.

Como vimos, existem diversas correntes acerca do interesse social que impactarão diretamente na atuação dos membros do conselho de administração quando da ocorrência de uma oferta pública. Sob a ótica contratualista, poder-se-ia argumentar que o conselho de administração da Eletropaulo deveria ter buscado ao máximo maximizar o ao máximo os valores ofertados, pouco se preocupando com a capitalização da Eletropaulo. Por outro lado, à luz da corrente institucionalista, tal órgão social deveria ter procurado aumentar ao máximo o valor a ser capitalizado na Eletropaulo pelo ofertante, não tendo que levar em conta necessariamente o preço a ser pago pelas ações dos acionistas da Eletropaulo.

Contudo, filiamo-nos à teoria mista que determina que os diversos interesses em jogo devem ser ponderados e que o resultado de tal ponderação será o interesse social. Assim, no Caso Eletropaulo, a fim de determinar qual seria o interesse social, fez-se preciso inicialmente ponderar os interesses envolvidos para avaliar se tais interesses poderiam ser atendidos ao mesmo tempo ou não. Considerando que nenhuma das ofertantes representava uma ameaça à Eletropaulo, e que tanto a OPA Enel quanto a OPA Neoenergia atendiam ao interesse de capitalização da 
companhia, e que os preços ofertados aumentavam sucessivamente, verificou-se a possibilidade de coexistência destes interesses.

Com base na constatação acima, resta questionar como deve se interpretar a legalidade da atuação do conselho de administração. Nessa seara, entendemos que os Deveres Revlon poderão nortear a aplicação dos arts. $153,154, \S 1^{\circ}$, e 155 , II, da LSA.

Dessa forma, os Deveres Revlon, em tese, corroborariam a atuação do conselho de administração da Eletropaulo quando da decisão tomada na RCA 25.04.2018 de cancelar a Oferta Primária, de forma a manter o processo competitivo em andamento. Esta decisão não se baseou apenas no alto preço então ofertado pela Enel para aquisição das ações de emissão da Eletropaulo, tendo sido tomada também pelo fato de a OPA Enel prever, em seu edital, a capitalização posterior da Eletropaulo, de modo a atender aos dois interesses, e, por conseguinte, ao interesse social. ${ }^{205}$

Assim, quando deparado com essa situação, não enxergando qualquer ameaça nos ofertantes concorrentes, não caberá aos administradores conferir tratamento especial a um ou a outro, devendo atuar de forma a maximizar o valor das ações dos acionistas.

Foi o que parece ter ocorrido ${ }^{206}$, uma vez que, por força da manutenção do processo competitivo, houve, em relação à proposta inicial da Enel, uma valorização de mais de $61 \%$ no valor ofertado por ação, sem prejuízo da capitalização da Eletropaulo.

Dessa forma, todos os interesses em jogo estariam atendidos. A Eletropaulo provavelmente obterá a capitalização prometida, e seus

\footnotetext{
${ }^{205}$ Não adentraremos de forma alguma no fato de a Enel ser subsidiária de uma companhia italiana e ter passado a dominar o setor elétrico brasileiro. Análises como esta, de cunho político e ideológico, não fazem parte do escopo da presente monografia.

${ }^{206}$ Obviamente, por força do sigilo do procedimento arbitral em trâmite perante a CAM, não tivemos acesso aos autos. Assim, não temos como afirmar que de fato a Eletropaulo cumpriu integralmente o Acordo de Investimento. Todavia, com base na informação fornecida no Fato Relevante da Eletropaulo de 16 de abril de 2018, o Acordo de Investimento seria automaticamente extinto caso o conselho de administração da Eletropaulo deliberasse pelo cancelamento da Oferta Primária. Dessa forma, nossa análise parte da premissa de que o Acordo de Investimento fora regularmente extinto.
} 
acionistas maximizaram significativamente o valor de seus investimentos $^{207}$.

Os Deveres Revlon, portanto, podem ser utilizados como princípio norteador para embasar e orientar a aplicação dos referidos dispositivos legais quando da análise da atuação do conselho de administração ao ser confrontado com ofertas públicas concorrentes, tal como aconteceu no Caso Eletropaulo.

Analisados os principais casos relacionados à atuação do conselho de administração em ofertas públicas, faremos, por derradeiro, alguns questionamentos acerca da configuração usual das cláusulas de proteção à dispersão acionária no mercado brasileiro. Isto é, as cláusulas de dispersão acionária precisam necessariamente manter a estruturação atualmente apresentada?

Como se sabe, a inclusão destes dispositivos virou uma epidemia sob o argumento de se tratar de uma medida de governança corporativa que teria por objetivo manter disperso o capital social das companhias abertas que incluíam estes dispositivos em seus estatutos sociais. A prática, entretanto, demonstrou que tais cláusulas visavam única e exclusivamente dar uma relativa estabilidade ao poder dos controladores minoritários. Dessa forma, as cláusulas de proteção à dispersão acionária acabam, por mais contraditório que seja, por funcionar como um mecanismo de manutenção do controle concentrado.

Em relação a tal utilização, entretanto, não faremos qualquer tipo de juízo valorativo. Ou seja, como já elucidamos, o presente estudo não visa defender que o controle diluído seja melhor ou pior que o controle concentrado. Buscamos apenas a afirmar algo que já é notório na prática societária: a utilização destas cláusulas se dá, pelo menos em regra, para

\footnotetext{
${ }^{207}$ Em 26 de junho de 2018, foi publicada uma Comunicação sobre Transações entre Partes Relacionadas pela Eletropaulo na qual se informava que seu conselho de administração havia aprovado a celebração do Termo de Adiantamento para Futuro Aumento de Capital com a Enel no montante de $\mathrm{R} \$ 900.000 .000,00$. Até o fechamento da edição da presente monografia, a capitalização não foi efetuada.
} 
conferir estabilidade ao poder do controlador minoritário, não havendo nada de irregular neste artifício.

Contudo, o que se viu com a crise econômica de 2008 e que se constata no cenário atual, é que tais cláusulas geram uma forte iliquidez nas ações. Em outras palavras, os acionistas não controladores, que geralmente visam apenas auferir lucros sem qualquer pretensão de exercer poder de comando sobre a companhia, não encontravam ninguém para quem pudessem alienar suas ações a um valor justo, pois os diversos interessados muitas vezes desejavam obter uma participação de pelo menos $50 \%$ do capital e não poderiam fazê-lo sem a necessidade de realizar uma oferta pública para aquisição das demais ações a preço muitas vezes irreais.

O mesmo pode ser dito até em relação ao controlador minoritário, especialmente nas situações em que seu poder controle estivesse ameaçado em razão de terceiros que estejam elevando suas participações a níveis semelhantes àquela detida por tal controlador.

Não obstante a problemática acima, fato é que as cláusulas de proteção à dispersão acionária obstam a concretização de ofertas públicas que representem ameaças ao interesse social. A questão, portanto, é que tais dispositivos estatutários acabam por obstar ofertas em geral, sejam elas amigáveis ou hostis, benéficas ou prejudiciais.

Assim, pensamos que as cláusulas de proteção à dispersão acionária podem assumir configurações mais flexíveis.

Pode-se cogitar, por exemplo, um dispositivo cuja eficácia perduraria por 1 (um) exercício social, podendo ser prorrogada por igual período por meio de decisão tomada em assembleia geral extraordinária a ser preferencialmente realizada simultaneamente à assembleia geral ordinária do pertinente exercício social. Dessa forma, os acionistas poderão, com base nas condições e perspectivas do mercado para aquele período, avaliar melhor a conveniência ou não de tal dispositivo estatutário. 
Em relação a potenciais efeitos negativos advindos desta estrutura, não haveria sequer prejuízo ao controlador minoritário, pois ele provavelmente prevalecerá em tal deliberação, podendo inclusive dela se beneficiar. Por sua vez, os acionistas não controladores continuarão sujeitos ao arbítrio do controlador que, caso queira, provavelmente conseguirá retirar este dispositivo do estatuto social, seja qual for a sua forma de estruturação. Assim, em relação a estes acionistas também não haverá um prejuízo maior do que já ocorre na atual configuração apresentada pelas cláusulas de proteção à dispersão acionária, face à iliquidez pode elas geradas sobre as ações da companhia.

No mercado brasileiro, algumas companhias já tiveram (e algumas ainda têm) em seus estatutos sociais a possibilidade de dispensa da aplicação concreta das cláusulas de proteção à dispersão acionária por meio de decisão da assembleia geral ${ }^{208}$. Entretanto, tal medida pouco mitiga a questão da redução da pressão sofrida pelos acionistas em casos de ofertas públicas, uma vez que, a depender das condições de mercado e do preço ofertado, é provável que os acionistas alienem suas participações em razão da pressão sobre eles exercida por força da oferta formulada.

De forma a permitir as já delineadas vantagens do envolvimento do conselho de administração nas ofertas hostis, em especial na redução da assimetria informacional e da pressão exercida sobre os acionistas, poderse-ia pensar também em um modelo que previsse no estatuto social a possibilidade de suspensão temporária da eficácia da cláusula de proteção à dispersão acionária por meio de uma decisão fundamentada do conselho de administração, a ser tomada em reunião deste órgão social, com a observância de seus deveres fiduciários, quando informado da existência de um terceiro que esteja interessado em realizar uma oferta pública para

\footnotetext{
${ }^{208}$ É o caso da Aliansce Shopping Centers S.A., GAEC Educação S.A. (Anima), Biosev S.A., BR Malls Participações S.A., Brasil Pharma S.A., BR Properties S.A., Direcional Engenharia S.A., JBS S.A., Mills Estruturas e Serviços de Engenharia S.A., Minerva S.A., Natura Cosméticos S.A., FPC Par Corretora de Seguros S.A., Raia Drogasil S.A., Rossi Residencial S.A., SLC Agrícola S.A., T4F Entretenimento S.A., e Wiz Soluções e Corretagem de Seguros S.A.
} 
adquirir determinado percentual acima do gatilho previsto pela cláusula. É o que se previa, ainda que de maneira incipiente no $\S 13^{\circ}$ do art. 38 do estatuto social da Brasil Insurance Participações e Administração S.A. ("BR Insurance") que estabelecia que a cláusula de proteção à dispersão acionária, prevista no caput deste dispositivo estatutário, poderia "ser dispensada mediante aprovação do conselho de administração da companhia." 209

Ainda que concordemos com a ideia outrora contida no estatuto social da BR Insurance, entendemos que o dispositivo em questão deve ser regulamentado de maneira mais minuciosa para evitar possíveis distorções. Para tanto, em nossa opinião, tal cláusula deverá prever que o conselho de administração deverá publicar um Aviso aos Acionistas de forma a dar a estes ciência da decisão tomada.

Além disso, a eficácia da decisão do conselho de administração que deliberou pela suspensão da eficácia da cláusula de proteção à dispersão acionária só passaria a ter efeitos a partir de um determinado prazo não muito extenso. Durante este prazo, os acionistas poderão, por óbvio, em razão da soberania da assembleia geral, revogar a decisão tomada em reunião do conselho de administração, caso queiram, por meio de uma assembleia geral extraordinária, ou, ainda, impor outras condicionantes como, por exemplo, alteração do preço mínimo a ser pago por ação, do prazo e da forma de pagamento, da divulgação dos planos do ofertante para o futuro da companhia, dentre outras questões.

Dessa forma, os acionistas delegariam uma competência ao conselho de administração, que pela lei não é privativa da assembleia geral, sem que esta perdesse sua soberania.

Tal medida estimularia o envolvimento do conselho de administração nas tomadas de controle, pois o interessado verá um meio

\footnotetext{
${ }^{209}$ Versão do estatuto social da BR Insurance de 25 de novembro de 2015. Disponível em: $<\mathrm{http} / / /$ siteempresas.bovespa.com.br/consbov/ArquivoComCabecalho.asp? motivo=\&protocolo $=49$ 2614\&funcao $=$ visualizar $\&$ Site $=C>$. Acesso em 09.07.2018.
} 
mais célere e potencialmente mais eficaz para se sobrepor à limitação prevista pela cláusula de proteção à dispersão acionária, uma vez que não necessariamente precisará aguardar uma autorização assemblear e contarão com o apoio daqueles que teriam a maior propensão a serem contrários a tal oferta e que estão na melhor posição para avaliar a conveniência da oferta, tanto em relação ao preço oferecido quanto em relação aos impactos que esta trará, caso concretizada, aos planos e atividades sociais da companhia. Desse modo, por meio desta cláusula, diversos interesses poderiam ser atendidos.

Conforme informado, os acionistas, em sua generalidade, permaneceriam com a decisão final acerca da aceitação ou não da oferta, visto que a assembleia geral manteria sua soberania ao poder não só revogar a decisão do conselho de administração pela suspensão da eficácia de tal dispositivo estatutário ou impor determinadas condicionantes para a aceitação da oferta, como também ao poder a qualquer tempo alterar o estatuto de forma a retirar tal competência da esfera do conselho de administração.

Ademais, os acionistas também seriam beneficiados pelo envolvimento da administração nas ofertas hostis, visto que, no cenário de forte pulverização da base acionária, haverá o já mencionado problema da ação coletiva, que dificultará que estes negociem melhores termos e condições diretamente com o ofertante, razão pela qual terá este órgão social melhores condições para impor as mencionadas condicionantes. Além disso, o envolvimento da administração teria por efeito reduzir a pressão sofrida pelos acionistas gerada pelas ofertas públicas.

Por sua vez, em relação aos acionistas não controladores, percebe-se que estes terão maior liquidez nos seus títulos, visto que se facilitaria o processo de negociação, e se mitigaria a barreira gerada pela atual configuração das cláusulas de proteção à dispersão acionária, possibilitando, inclusive, o despertar de outros interessados que poderão 
formular ofertas concorrentes. Mais ainda, sua situação, ao cabo, não seria sequer muito alterada em razão desta nova roupagem, pois continuariam sujeitos a uma decisão do controlador (caso haja algum) de alterar tal dispositivo estatutário. Ou seja, poder-se-ia afirmar que aos acionistas lhes seria imposto o "menor dos males", uma vez que tal dispositivo facilitaria a alienação de suas ações, inclusive podendo partilhar do prêmio de controle a ser eventualmente pago, algo que o atual padrão das cláusulas de proteção à dispersão acionária não permite na prática, em razão das obrigações impostas por tais dispositivos e pelos abusivos preços neles estipulados.

Por último, o eventual controlador minoritário também não terá nada a perder, pois, não só haverá a manutenção da sua soberania através da assembleia geral, permitindo sua provável prevalência na eventual deliberação acerca da manutenção ou revogação de tal decisão do conselho de administração, bem como este terá elegido a maioria dos membros do conselho de administração, não tendo a princípio motivo para deles desconfiar, e, caso discorde da decisão tomada por este órgão, bastará ao controlador minoritário revogá-la por meio de uma assembleia geral extraordinária que se dará por quórum simples, uma vez que não se tratará de uma alteração ao estatuto social, mas sim de adequado exercício de uma faculdade lícita que neste fora regularmente inserida. Além disso, caso entenda que o dispositivo não é conveniente naquele determinado momento, bastará ao controlador retirá-lo do estatuto social, o que muito provavelmente conseguirá.

$\mathrm{O}$ intuito deste modelo de cláusula seria, portanto, alinhar os interesses das diversas partes envolvidas nas tomadas hostis. 


\section{CONCLUSÃO}

Buscamos analisar no presente estudo a atuação dos membros do conselho de administração quando em face de uma tentativa de uma tomada hostil de controle.

Assim, após conceituar e analisar as diversas modalidades do poder de controle, constatamos que: (i) o controle minoritário atualmente faz parte da realidade do mercado de capitais nacional; (ii) o controle gerencial não pode mais ser excluído das análises jurídicas, visto que há indícios de possibilidade de sua ocorrência em algumas companhias brasileiras, ainda que, casso haja de fato, em fase extremamente embrionária; e (iii) que a pulverização acionária leva a um aumento do poder da administração.

Em relação aos problemas decorrentes da pulverização do capital social, tecemos alguns comentários acerca da relação de agência entre administradores e acionistas que, em virtude do risco moral e da seleção adversa, dentre outros fatores, gera o conflito de agência que, por sua vez acarreta nos chamados "custos de agência" necessários para assegurar o alinhamento dos interesses do principal (acionistas) e do agente (administradores).

Em sequência, constatamos que, dentre as diversas formas de se alinhar os interesses das partes da relação de agência, encontram-se os deveres fiduciários e as tomadas hostis. Dessa forma, passamos a analisar tais institutos.

Em relação aos deveres fiduciários, analisamos o dever de diligência e o dever de lealdade, passando ainda por uma breve exposição da business judgment rule. Por sua vez, no que toca as tomadas hostis de controle, expusemos as suas vantagens, desvantagens e a maneira pela qual estas estão inseridas no ordenamento jurídico brasileiro.

A partir de tal análise, aferimos que, quando em face de uma tentativa de tomada hostil de controle, os administradores estão em um 
potencial conflito de interesses, razão pela qual passamos a expor o conceito e as teorias acerca do interesse social, a fim de possibilitar o exame do instituto do conflito de interesses.

Em seguida, demonstramos que nosso sistema legal carece de normas que regulem a atuação dos administradores nessa seara, motivo pelo qual devem ser aplicados os dispositivos legais referentes aos deveres fiduciários.

Face a constatação da ausência de normas expressas que regulem a atuação dos membros do conselho de administração em ofertas públicas, socorremo-nos de referências interpretativas fornecidas pelo sistema europeu, em especial o do Reino Unido, e pelo sistema norte-americano.

Após examinar esses dois modelos, percebemos que o modelo norteamericano é o que mais se coaduna ao sistema brasileiro, ainda que dele se divirja amplamente graças à significativa alocação de poderes nas mãos da assembleia geral que ocorre por força da nossa legislação. No entanto, apesar desta relevante distinção, entendemos que seria possível importar, com importantes adaptações, os deveres estabelecidos pelos casos Unocal e Revlon que poderão guiar e auxiliar a interpretação da regularidade da atuação dos administradores em conjunturas de ofertas públicas, porém sempre tendo por norte o interesse social.

Em razão do já mencionado vácuo legislativo, listamos algumas condutas legalmente passíveis de realização pelo conselho de administração a fim de obstar uma tomada hostil. Assim, explicitamos que o conselho de administração poderá e deverá, conforme o caso, (i) realizar um pedido público de procuração para alterar o estatuto de forma a incluir uma cláusula de proteção à dispersão acionária ou uma cláusula que limite o número de votos que podem ser exercidos por cada acionista, (ii) buscar um ofertante concorrente (white knight) e (iii) elaborar um parecer, expondo os motivos pelos quais entende que a concretização da oferta hostil seria 
prejudicial, para, com isso, convencer os acionistas acerca da existência de uma ameaça ao interesse social.

Em sequência, analisamos os casos GVT, DASA e Eletropaulo que deram azo a questionamentos referentes ao papel do conselho de administração em ofertas públicas.

Por fim, tecemos breves comentários acerca dos efeitos gerados pela atual configuração das cláusulas de proteção à dispersão acionária e oferecemos algumas sugestões a fim de mitigar os problemas que podem advir desses dispositivos estatutários. 


\section{BIBLIOGRAFIA}

AKERLOF, George. The Market for lemons: quality uncertanty and the market mechanism. Quarterly Journal of Economics, 84 (1970): 488-500.

AZEVEDO, Luís André N. de Moura. Ativismo dos Investidores Institucionais e Poder de Controle nas Companhias Abertas de Capital Pulverizado Brasileiras. In CASTRO, Rodrigo R. Monteiro de; - (Coord.). - Poder de Controle e Outros Temas de Direito Societário e Mercado de Capitais. São Paulo: Quartier Latin, 2010.

AZEVEDO, Luís André N. de Moura. Controle Minoritário: Dissociação entre Voto e Participação Econômica na Companhia Aberta - Coleção IDSA de Direito Societário e Mercado de Capitais - Volume 8. São Paulo: Quartier Latin, 2017.

BARRETO, Júlio. O Conflito de Interesses entre a Companhia e seus Administradores. Rio de Janeiro: Renovar, 2009.

BENSAL, Bruno Marques. A Business Judgment Rule no Direito Brasileiro: da Responsabilidade dos Administradores na Perspectiva do Direito Comparado e na Jurisprudência da CVM. Revista De Direito Empresarial, v. 7, jan/fev, 2015. p. 111-131.

BRIGAGÃO, Pedro Henrique Castello. A Business Judgment Rule no Direito Brasileiro: A Problemática da Recepção da Regra pela Lei das S.A. Revista de Direito Bancário e do Mercado de Capitais. v. 74 out/dez , 2016.

CARVALHOSA, Modesto. Comentários à Lei de Sociedades Anônimas. v. 4, t. II, $2^{\text {a }}$ ed. rev. São Paulo: Saraiva, 2003.

CARVALHOSA, Modesto. Comentários à Lei de Sociedades Anônimas, v. 4, t. II, $3^{a}$ ed. São Paulo: Saraiva, 2002.

CASTRO, Flávia de Almeida de Viveiros de. O modelo do bom pai de 
família e a responsabilidade civil contratual: Origens e Desdobramentos. Direito, Estado e Sociedade. Rio de Janeiro, n.15, p.17, ago./dez., 1999.

CINTRA, Antonio Carlos Fontes. Responsabilidade dos Administradores Perante a Má Fortuna do Negócio e a Business Judgment Rule. Revista de Direito Bancário e do Mercado de Capitais, v. 58, out, 2012. p. 54.

CLARK, Robert. Corporation law. Boston: Little Brown and Company, 1986.

COMPARATO, Fábio Konder; SALOMÃO FILHO, Calixto. $O$ poder de controle na sociedade anônima. $4^{\mathrm{a}}$ ed. Rio de Janeiro: Forense, 2005.

DAVIES, Paul L. Shareholder Value: Company Law and Securities Markets Law - A British View. Out. 2000.

EASTERBROOK, Frank; FISCHEL, Daniel. The economic structure of corporate law. Cambridge, Mass.: Harvard University Press, 1991.

EISENBERG, Melvin A. Corporations and other business organizations. New York: Foundation Press, 2000.

EIZIRIK, Nelson. A Lei das S/A Comentada. v. III. São Paulo: Quartier Latin, 2011.

EIZIRIK, Nelson. O mito do "controle gerencial": alguns dados empíricos. Revista de Direito Mercantil, Industrial, Econômico e Financeiro. São Paulo: Malheiro, n. ${ }^{\circ}$ 66, p. 103-106, abr./jun., 1987.

EIZIRIK, Nelson; GAAL, Ariádna B; Parente, Flávia; HENRIQUE, Marcus de Freitas. Mercado de capitais - regime jurídico. 3.ed. revista e ampliada. - Rio de Janeiro: Renovar, 2011.

EIZIRIK, Nelson; HENRIQUES, Marcus de Freitas; VIEIRA, Juliana Botini Hargreaves. O Cômite de Aquisições e Fusões: Versão Brasileira do Takeover Panel. In: KUYVEN, Luiz Fernando Martins (Coord.). Temas essenciais de direito empresarial. São Paulo: Saraiva, 2012.

FERREL, Allen. Why Continental European Takeover Law Matters. 
Harvard John M. Ollin Center for Law, Economics and Business Discussion Paper, n. ${ }^{\text {454, p. 11, } 2003 .}$

FREITAS, Clarissa Figueiredo de Souza. Os poderes do conselho de administração para impor medidas defensivas contra ofertas hostis no direito comparado e na legislação brasileira. Revista de Direito Mercantil, Industrial, Econômico e Financeiro, São Paulo: Malheiros, v. 159/160, p. 127-141, jul./dez. 2011.

GUERREIRO, José Alexandre Tavares. Sociedade Anônima: poder e dominação. Revista de Direito Mercantil, Industrial, Econômico e Financeiro, Nova Série, ano 23, n. ${ }^{\circ}$ 53, p. 73-80, jan./mar. 1984.

JENSEN, Michael C.; e MECKLING, William H. Theory of the Firm: Managerial Behavior, Agency Costs and Ownership Structure. Journal of Financial Economics, October, 1976, V. 3, No. 4.

JORGE, Fernando de Sandy Lopes Pessoa. Ensaio sobre os Pressupostos da Responsabilidade Civil. Coimbra: Almedina, 1999.

LAMY FILHO, Alfredo; PEDREIRA, José Luiz Bulhões (Coord.). Direito das companhias. 2.ed. atual. refor. Rio de Janeiro: GEN, Forense, 2017.

MACEDO, Ricardo Ferreira de. Controle Não Societário. Rio de Janeiro: Renovar, 2004.

MELLO, Carlos Barbosa e DE CARVALHO, André Ziccardi. Controle Difuso, Poison Pills e Hostile Take Over Bid. In. SIQUEIRA, Marcelo, PEREIRA, Atademes Branco e TREIGER, José Marcos. Brasil S/A: Guia de Acesso ao Mercado de Capitais para Companhias Brasileiras - Rio de Janeiro: RR Donnelley Financial Comunicação Corporativa, 2014.

MUNHOZ, Eduardo Secchi. Empresa Contemporânea e direito societário. São Paulo: Juarez de Oliveira, 2002.

NASCIMENTO, João Pedro Barroso do. Medidas Defensivas à Tomada de Controle de Companhias. São Paulo: Quartier Latin, 2011. 
O'KELlEY, Charles R. T.; THOMPSON, Robert B. Corporations and other business associations. $5^{\mathrm{a}}$ ed. New York: Aspen Publishers, 2006.

OECD Corporate Governance Factbook. OECD, 2014.

OIOLI, Erik Frederico. Oferta pública de aquisição do controle de companhias abertas. São Paulo: Quartier Latin, 2010.

OLIVEIRA, Flávia Jardim de, e CARVALHO, Gabriela Cerqueira de. $O$ Controle Gerencial e a Responsabilização do Administrador em Caso de Conflito de Interesses. São Paulo. Red GV. v. 01, n. 03, jul/2013, artigo 03.

PARENTE, Flávia. $O$ dever de diligência dos administradores de sociedades anônimas. Rio de. Janeiro: Renovar, 2005.

PARGENDLER, Mariana. Modes of gap filling: good Faith and fiduciary duties reconsidered. Tulane Law Review, v. 82, 2008.

POSNER, Richard A. Economic Analysis of Law. 6. ed. New York: Aspen, 2003.

PRADO, Roberta Nioac. Oferta pública de ações obrigatória nas S.A. - tag along. São Paulo: Quartier Latin, 2005.

RATHENAU, Walther. Do Sistema Acionário - uma análise negocial. Tradução e introdução de Nilson Lautenschleger Jr. Revista de Direito Mercantil, n 128, a. XLI, p. 214, out./dez. 2002.

RIBEIRO, Renato Ventura. Direito de Voto nas Sociedades Anônimas. São Paulo: Quartier Latin, 2009.

ROBERT, Bruno. Exercício do direito de voto nas assembleias das companhias brasileiras, pedidos públicos de procuração, voto $e$ participação à distância. Tese de doutorado. Orientador: Eduardo Secchi Munhoz. Faculdade de Direito da Universidade de São Paulo: São Paulo, 2012.

SADDI, Jairo. Conflito de Interesses no Mercado de Capitais. In CASTRO, Rodrigo R. Monteiro de; ARAGÃO, Leandro Santos de (Coord.). 
Sociedade Anônima. São Paulo: Quartier Latin, 2007.

SALOMÃO FILHO, Calixto. O novo direito societário. $3^{\mathrm{a}}$ ed. São Paulo: Malheiros.

SALOMÃO FILHO, Calixto; RICHTER JÚNIOR, Mário Stella. Interesse Social e Poderes dos Administradores na Alienação do Controle. In: RDM, n. ${ }^{\circ} 89$.

SCALZILLI, João Pedro. Mercado de Capitais, Ofertas Hostis e Técnicas de Defesa. São Paulo: Quartier Latin, 2015.

SILVA, Carlos Alexandre Lobo e. A evolução da aquisição de controle de companhias abertas no Brasil. In: SILVA, Alexandre Couto [coordenador]. Direito societário. São Paulo: Saraiva, 2013.

VELASCO, Julian. The Enduring Illegitimacy of the Poison Pill. In: The Journal of Corporation Law, vol. 27, nº 3, 2002.

YAZBEK, Otávio. Regulação do Mercado Financeiro e de Capitais. Rio de Janeiro: Elsevier, 2009. 